\title{
Sanctioning Violence against Female Street Level Sex Workers: The Canadian Government's Failure to Take Up the Challenge of Change
}

\author{
By
}

Deanna Campbell, B.A. (Hons.)

A thesis submitted to the Faculty of Graduate Studies and Research in partial fulfillment of the requirements of the degree of

Master of Arts

\author{
Department of Law \\ Carleton University \\ Ottawa, Ontario \\ April $1^{\text {st }} 2008$
}

(C) 2008, Deanna Campbell 


$\begin{array}{ll}\begin{array}{l}\text { Library and } \\ \text { Archives Canada }\end{array} & \begin{array}{l}\text { Bibliothèque et } \\ \text { Archives Canada }\end{array} \\ \begin{array}{l}\text { Published Heritage } \\ \text { Branch }\end{array} & \begin{array}{l}\text { Direction du } \\ \text { Patrimoine de l'édition }\end{array} \\ \begin{array}{l}\text { 395 Wellington Street } \\ \text { Ottawa ON K1A 0N4 } \\ \text { Canada }\end{array} & \begin{array}{l}\text { 395, rue Wellington } \\ \text { Ottawa ON K1A 0N4 } \\ \text { Canada }\end{array}\end{array}$

Your file Votre référence

ISBN: 978-0-494-40593-2

Ourfile Notre référence

ISBN: 978-0-494-40593-2

NOTICE:

The author has granted a nonexclusive license allowing Library and Archives Canada to reproduce, publish, archive, preserve, conserve, communicate to the public by telecommunication or on the Internet, loan, distribute and sell theses worldwide, for commercial or noncommercial purposes, in microform, paper, electronic and/or any other formats.

The author retains copyright ownership and moral rights in this thesis. Neither the thesis nor substantial extracts from it may be printed or otherwise reproduced without the author's permission.
AVIS:

L'auteur a accordé une licence non exclusive permettant à la Bibliothèque et Archives Canada de reproduire, publier, archiver, sauvegarder, conserver, transmettre au public par télécommunication ou par l'Internet, prêter, distribuer et vendre des thèses partout dans le monde, à des fins commerciales ou autres, sur support microforme, papier, électronique et/ou autres formats.

L'auteur conserve la propriété du droit d'auteur et des droits moraux qui protège cette thèse. $\mathrm{Ni}$ la thèse ni des extraits substantiels de celle-ci ne doivent être imprimés ou autrement reproduits sans son autorisation.
In compliance with the Canadian Privacy Act some supporting forms may have been removed from this thesis.

While these forms may be included in the document page count, their removal does not represent any loss of content from the thesis.
Conformément à la loi canadienne sur la protection de la vie privée, quelques formulaires secondaires ont été enlevés de cette thèse.

Bien que ces formulaires aient inclus dans la pagination, il n'y aura aucun contenu manquant.

\section{Canada}




\begin{abstract}
This thesis examines the Government of Canada's failure to address the pervasive culture of violence against female street level sex workers. An examination of the literature and research, along with committees and reports mandated to examine prostitution, ending with the most recent Government Report (2006) The Challenge of Change, makes it very clear that the pandemic of abuse and violence that dominates the lives of sex workers has been evident for decades. Despite this overwhelming evidence, the Government continues to avoid and ignore the issue. I attribute this failure to the Government's and the public's focus on the "problem" of prostitution and the debates surrounding its legality and morality that flow from this characterization of prostitution. This misfocus prevents us from addressing the critical issues, leaving these women vulnerable to violence and abuse. Focusing directly on the experiences of violence against prostitutes (harassment, abuse, rape and murder), rather than the "status" of prostitution, this thesis frames the problem of violence against female sex workers as part of the larger issue of violence against women and argues that this approach would help us move away from stagnating debates and into action to address the issue of violence against prostitutes.
\end{abstract}




\section{ACKNOWLEDGEMENTS}

I would first and foremost like to thank my supervisor Diana Majury. Her guidance and encouragement has been endless and I cannot thank her enough. My writing and analytical abilities have been strengthened, and my knowledge has been broadened as a result of her supervision. It was an honour and a pleasure to work with her.

I would like to thank my family (Mom, Greg, Dad, Lisa, my sisters and grandparents) for their unending support and pride.

I would also like to thank my friends who have patiently supported me through this process especially Nicole, Stella, Alano, Victoria and Jessica.

A very honourable mention to Raj for all his help and suggestions and for being there when I needed someone to discuss ideas with. 


\section{DEDICATION}

This thesis is in honour of all the women who have been victimized or lost their lives while working on the streets. 


\section{TABLE OF CONTENTS}

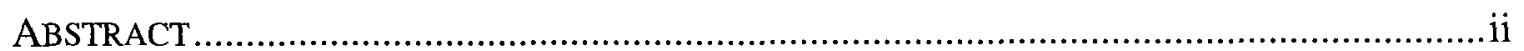

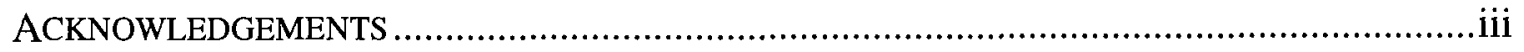

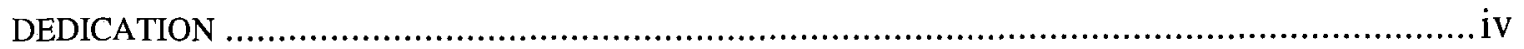

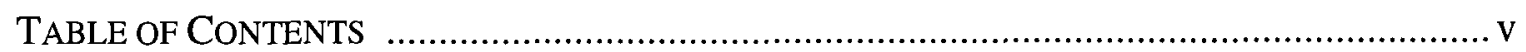

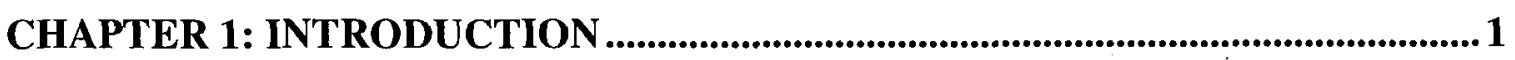

VIOLENCE AGAINST FEMALE STREeT PROSTITUTES ............................................. 2

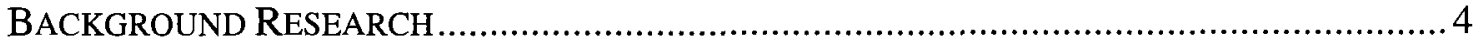

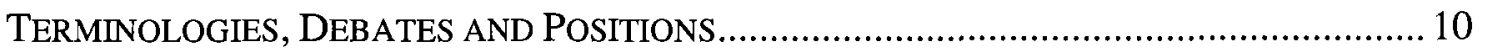

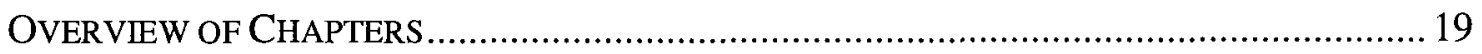

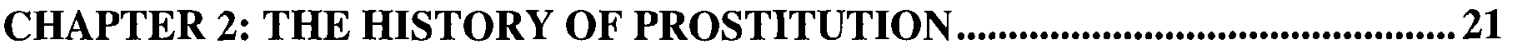

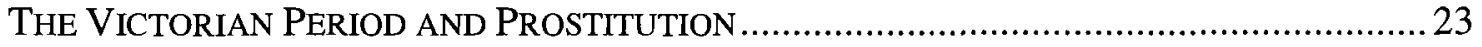

WHO WAS THE PROSTITUTE? .......................................................................... 28

PROSTITUTION LAW AND VICTORIAN SOCIETY: THE BRITISH AND CANADIAN

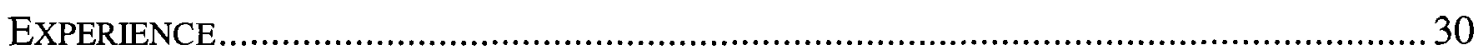

ThE MoRAL REFORMERS AND LEGISLATIVE CHANGE .............................................. 34

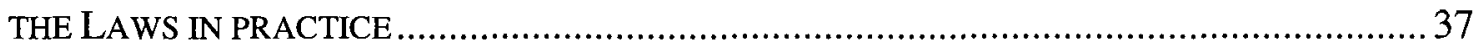

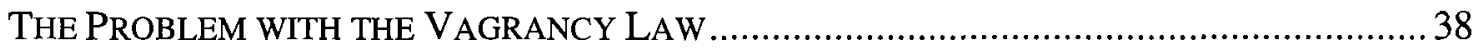

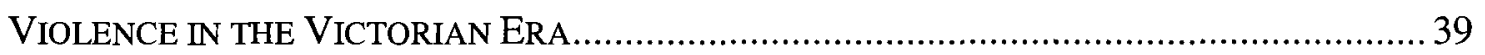

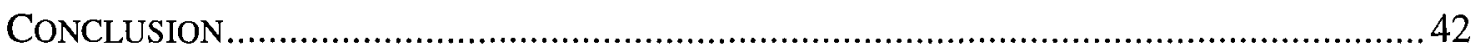

CHAPTER 3: A CULTURE OF VIOLENCE: DISCRIMINATION, ABUSE, AND MURDER OF FEMALE STREET PROSTITUTES IN CANADA..........................44

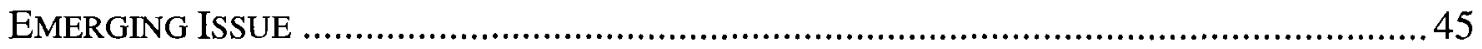

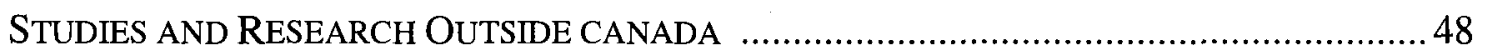

THE CANADIAN CONTEXT .............................................................................. 50

SEX WORKERS WORKING FOR THEIR SAFETY ................................................. 52

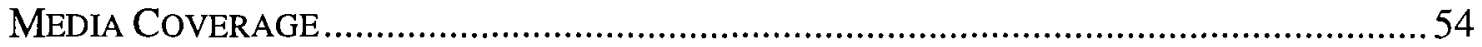

THE EXPERIENCE OF VIOLENCE: SOCIAL AND LEGAL MARgINALIZATION.......................55

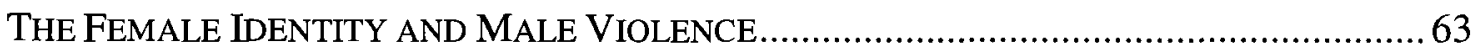

A COMBINATION OF FACTORS ................................................................... 70

CHAPTER 4: REPORTS ON THE 'PROSTITUTION PROBLEM”....................... 72

COMMITTEE ON SEXUAL OFFENCES AGAINST CHILDREN AND YOUTH - THE BADGLEY

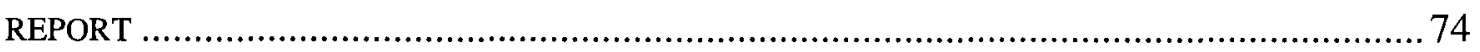

SPECIAL COMMITTEE ON PROSTITUTION AND PORNOGRAPHY IN CANADA - THE FRASER

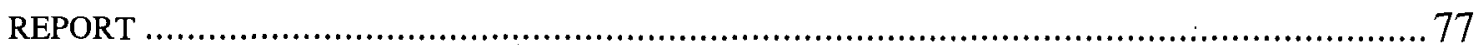

THE FEDERAL/PROVINCIAL/TERRITORIAL WORKING GROUP ON PROSTITUTION ............... 89

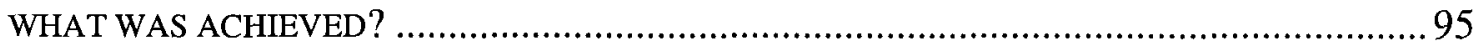

CHAPTER 5: DECONSTRUCTING THE PROSTITUTION PROBLEM AND

RECONSTRUCTING VIOLENCE AGAINST PROSTITUTES ...............................97

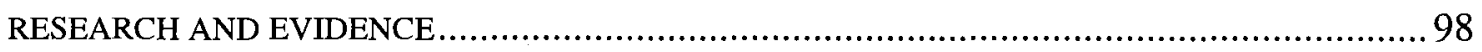

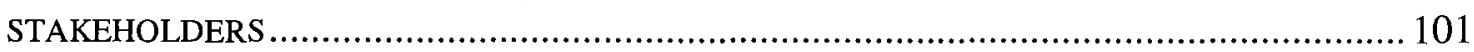




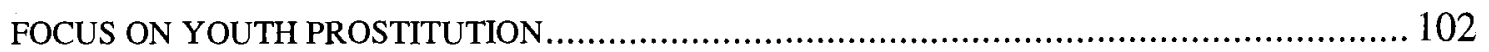

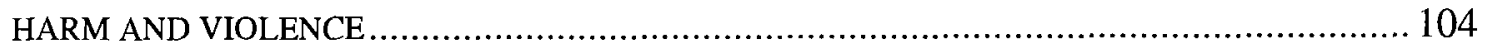

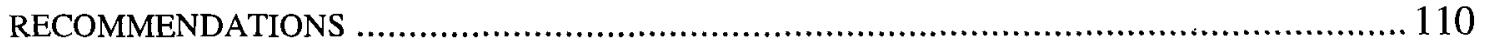

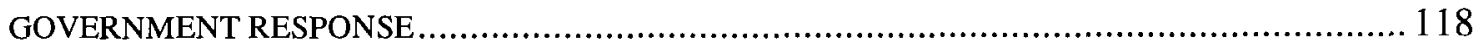

RE THINKING AND RE EXAMINING PROSTITUTION AND VIOLENCE ............................. 122

CHAPTER 6: THE CHALLENGE OF CHANGE ..................................................... 126

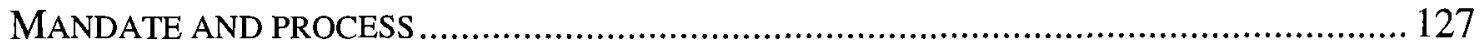

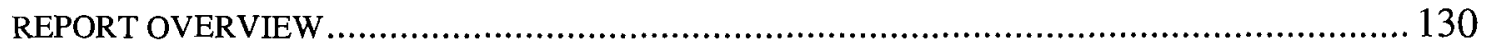

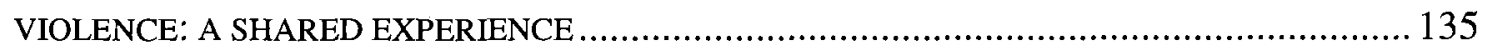

SEX WORKER, SEX WORKER ORGANIZATIONS AND OTHER FEMINIST PERSPECTIVES....... 138

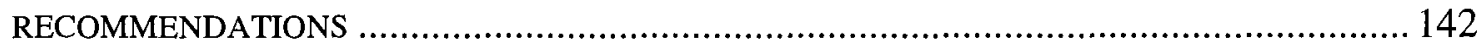

OVERALL RESPONSE TO REPORT AND RECOMMENDATIONS..................................... 151

CHAPTER 7: CONCLUSION - TAKING UP THE CHALLENGE ........................156

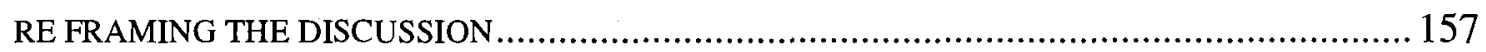

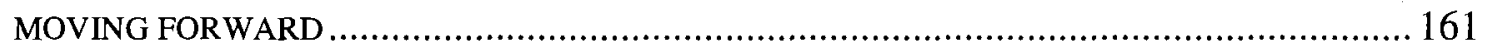

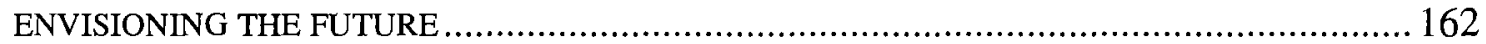

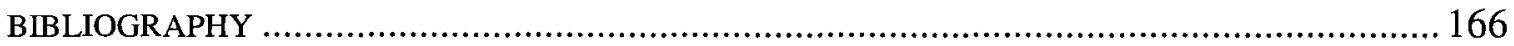

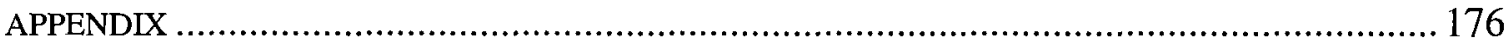


"It is justice, not charity, that is wanting in the world."

-Mary Wollstonecraft - A Vindication of the Rights of Woman, 1792- 


\section{Chapter 1}

\section{Introduction}

Prostitution is a complex and controversial topic that ignites debate on morals, the role of criminal law and female sexuality and exploitation. Discussion of prostitution is usually approached in the context of being a "social problem;" remedies are sought through legalization, decriminalization, or maintenance of the status quo of criminalization. Recently the issue of prostitution has remerged in Canada in a slightly different context. The significant number of women who have gone missing or been murdered in many cities across Canada has garnered the attention of feminists, the media, government and the general public. What links these women together is that they all worked in the sex trade, most of them as street prostitutes. ${ }^{1}$ Violence in the lives of prostitutes is in no way a new phenomenon. Women who work in the sex trade, particularly those who work on the streets, have always been the subject of physical, emotional and psychological abuse from society, legal officials, pimps and most commonly their clients. This violence has largely gone unnoticed until recent events made it impossible to ignore. The highly publicized incidents, investigations, arrests and trials involving murdered and missing sex workers within the past several years have led to intense media coverage. This in turn has sparked much comment and discussion on prostitution, and violence against prostitutes nationwide. Coinciding with this, has been the ever increasing activism and lobbying of feminists, and in particular prostitutes' rights groups, including prostitutes themselves, who have been actively educating the

\footnotetext{
${ }^{1}$ See infra, at page 10 for the explanation of the use of terms in this thesis.
} 
public on the issues prostitutes face, including the particularized forms of violence experienced by prostitutes.

\section{Violence against Female Street Prostitutes}

Much has been said by academics and researchers on prostitution globally and in the Canadian context. My focus is the examination of violence against female street level sex workers in Canada. In recent years, research and writings have taken up the problematic and ineffective nature of Canada's prostitution laws, as well as the stigmatization and marginalization that sex workers face. Stereotypes and discrimination persist in the lives of prostitutes as a result of long-standing myths surrounding female sexuality and sex work in general. Important academic and government-funded research has produced studies and writings on violence against sex workers in Canada. I hope to make my own contribution to this literature at a time when legal, political and social reform and insight on this issue are much needed.

Statistics, studies, and media coverage provide an alarming picture of missing and murdered women who worked in the sex trade in Canada. These atrocities span a period of 20 to 25 years in terms of government knowledge of the violence but it is only recently that awareness has been raised among the public. Some obvious questions emerge. Why have these women been subjected to such high levels of violence and why has nothing been done to address this extreme form of violence against women? Why has it taken so long for this issue to grab public attention? Why are we as a society and government only now starting to react? These questions lead to the primary inquiry of my thesis which is: How has the Canadian Government responded to the severe misogynistic violence that is so overwhelmingly embedded in the lives of street prostitutes? What has 
been done to address this violence? I hypothesize that the woman's identity as a prostitute is tied up in the lack of a response to this violence by government, legal officials and society as a whole. In my research I shift the focus away from the traditional debates surrounding prostitution to a clear and direct focus on violence against prostitutes. I have made this shift in an effort to engage in a more contemporary analysis of this much researched area, placing emphasis on the prostitutes' experiences of violence, rather than the status of prostitution itself. In doing this, I frame the problem of violence (harassment, abuse, rape and murder) against female sex workers as part of the larger issue of violence against women in general.

Since the 1980's there have been a number of committees on prostitution, and the Government of Canada has commissioned and released a number of reports and studies on the issue. Grounding my analysis in feminist theory, existing research and studies, and the violence against women literature, my thesis explores the above questions, and the extent to which these studies and reports address the issue of violence against prostitutes, and what if anything, has been done as a result of these reports and the recommendations they put forward. What I am interested in is the possibility that the exclusive focus of government (and other key players) on the debates over the public harm of prostitution, the assumed to be exploitative nature of the practice and proposed legal solutions (i.e. legalization, criminalization and so forth) have left prostitutes vulnerable to the violence that plagues them. Focusing attention on the debates and the traditional moral dilemma of legitimating sex work has allowed violence against female street prostitutes not only to persist, but I would argue increase. In other words, we have been focusing on the wrong thing. The government has a history of ignoring the issue of 
violence in favour of maintaining the status quo or even strengthening the criminalization of these women, thereby maintaining the stigmas and stereotypes that fuel mistreatment and discrimination and creating adversarial relationships with the justice system whereby prostitutes are made to feel and be seen as responsible for their own victimization. Street workers are left in vulnerable situations where they are exposed to violence. Prostitutes do not receive the same basic human rights and legal protections granted to other victims of violence and citizens more generally. The Canadian Government, and we as a society, have failed these women. I examine how and why this failure has occurred.

\section{Background Research}

\section{The Case of Pamela George}

Initially when I set out in my research, my aim was to examine the response of Canada's courts (via decisions) to incidents of rape, assault, murder and so forth when the victim is a prostitute. My question was whether stereotypes and myths regarding prostitutes were maintained and reinforced through judicial decision-making in cases involving the victimization of prostitutes. My intended line of inquiry was to investigate how much of a prostitute's identity is tied up in how she is treated by the justice system (in particular the courts and judges) when she is a victim of violence. I attempted to locate cases and examine decisions involving abuse, sexual assault and/or murder of female sex workers in order to determine whether anti-prostitute myths, stigma and discrimination were reflected in the language and perhaps outcomes of these decisions. My motivation for this research was an article by Sherene Razack about the Pamela 
George case. ${ }^{2}$ Pamela George was a young Aboriginal woman with two young children. She occasionally worked as a prostitute in Regina, Saskatchewan. She was murdered in 1995 by two young, middle class white men. They beat her so badly that her family was unable to have an open casket at her funeral. ${ }^{3}$ The men were convicted of manslaughter and sentenced to six and half years in prison. The outrage over the case and the trial stemmed from the short prison sentenced awarded the two young men and also, for lack of a stronger word, the "inappropriate" remarks of the presiding Judge, Justice Malone. During the trial, Pamela George was depicted as a legitimate target of the gendered and racialized violence inflicted on her by the two men. Because she may have consented to provide sexual services, the violence was seen as permissible. ${ }^{4}$ Just as Pamela George's identity as a prostitute was tied up in her mistreatment, so was her identity as an Aboriginal woman. Razack's argument is that Pamela George was treated as belonging to a space of race and sexuality that was outside the scope of universal justice. The men's and the court's capacity to dehumanize her came from their understanding of her as the gendered racial "other" whose degradation confirmed their own identities as white men entitled to the basic rights and liberties of Canadians. These men saw themselves as entitled to commit the acts they did against Pamela George because of her sexualized and racialized identity.

In instructing the jury, Judge Malone reminded them that Pamela George was "indeed a prostitute," when considering whether she consented to the sexual assault, with

\footnotetext{
${ }^{2}$ Sherene Razack, "Gendered Racial Violence and spatialized Justice: The Murder of Pamela George" in Race, Space and the Law: Unmapping a White Settler Society (Toronto: Between the Lines, 2002).

${ }^{3}$ Maggie's Toronto, Pamela George Murder Trial (2006) http://www.walnet.org./csis/regina 96/pam george.html (no longer available).

${ }^{4}$ Supra note 2 at 145 .
} 
the implication that prostitutes cannot be raped. ${ }^{5}$ The issue of consent was a determining factor in convicting the men of manslaughter rather than the more serious first degree murder. ${ }^{6}$ Judge Malone's discriminatory attitudes were already well known. He had expressed his racist, sexist and anti-prostitute bias in an earlier decision in which he had dismissed charges of unlawful confinement and sexual assault against a Regina pimp accused of attacking an 18 year woman who worked in the sex trade. Judge Malone wrote that he needed to deal with the complainant's background stating, "She admitted at the time of the offence she was a prostitute and did so until her pimp at the time beat her up. She even allowed herself to be sold by one pimp to another."7 He concluded that in these circumstances, "it would be unsafe to convict him." ${ }^{8}$ Such treatment and remarks dehumanize and devalue the lives of these particular women, as well as prostitutes in general.

After reading Razack's article, I felt a strong sense of injustice at the treatment of Pamela George. I found it incredulous that she was so dehumanized and her victimization minimized, because she was an Aboriginal woman, and because she was a prostitute. This raised many concerns and questions for me about the response of society and the justice system to all street level prostitutes when they are victims of abuse and violence. This in turn motivated me in my research.

\footnotetext{
${ }^{5}$ Ibid at 152 .

${ }^{6}$ Ibid.

${ }^{7}$ Maggie's Toronto, supra note 2.

${ }^{8}$ Ibid.
} 
Victimization and the Prostitute Identity in Court Decisions

Professor John Lowman of Simon Fraser University, who has been researching and writing on prostitution and violence against prostitutes for the past 30 years, cites several cases involving the victimization of prostitutes in his work. He references newspaper reports documenting specific cases and trials he has researched to demonstrate the severity of violence inflicted against female sex workers. ${ }^{9}$ One of these cases provides another graphic example of the judicial tendency to hold the prostitute responsible for her own victimization that was egregiously apparent in the Pamela George case. It was a decision in 1995 under the Criminal Injury Compensation Act. ${ }^{10}$ In denying compensation to a prostitute for injuries she sustained in an assault, the decision maker reasoned:

Prostitution is an inherently dangerous activity. The injuries Ms F sustained are precisely the kind of injuries which one might well expect to sustain while carrying out that course of conduct. Ms. F. placed herself in a vulnerable position, after soliciting. In all of the circumstances she contributed directly to the circumstances giving rise to this incident. ${ }^{11}$

A disturbing assumption is made in this decision that prostitution is inherently violent and dangerous. Nothing about the sale of sex for money is per se dangerous or invites violence. Stating or implying that it is condones and justifies the violence. The victimization of the prostitute is made invisible because of what she does and the

\footnotetext{
${ }^{9}$ See Larry Still "'Dangerous, violent' serial rapist convicted." Vancouver Sun, 22 December 1994, p. B4. (man convicted of stabbing prostitute 32 times); Claire Ogilvie, "Serial rapist dealt fourteen years for attacks on three women," Province, 6 January 1995, p. A10 (man convicted of violent sexual acts against three prostitutes); S. Bell and H. Munro "Pursued by twin dragons: a bleak past, grim future" Vancouver Sun, 18 January 1995, p. A2). (The case of Fernand Auger, convicted of sexually assaulting two teenage prostitutes and only getting two years less a day. Ten years later he sexually assaulted and murdered a young woman, Melanie Carpenter). Cases cited in John Lowman and Laura Fraser, Violence against Persons Who Prostitute: The Experience in British Columbia. Technical Report No. TR1996-14e. (Ottawa: Department of Justice Canada, 1996) available at: http://users.uniserve.com/ lowman/ ${ }^{10}$ The name of the case was not given but cited by Lowman as decision under the Criminal Injury Compensation Act 8 July 1993 in John Lowman and Laura Fraser, Ibid

${ }^{11}$ Lowman and Fraser, Ibid.
} 
assumption that what she does is by definition violent. The prostitute is stripped of her rights and protections and denied justice because of the work she performs. In the end, this woman did not receive any compensation.

This assumption of the inherent violence of prostitution underlies much of the reaction to prostitution generally and to violence against prostitutes specifically. It is a theme I will come back to in this thesis for further discussion and analysis.

These two cases are glaring examples of the mistreatment of prostitutes by the Canadian justice system. However, there are also examples of cases involving gruesome murder trials of prostitutes where the killers were given fairly lengthy prison sentences. ${ }^{12}$ While there is no record that judicial conduct in these cases demonstrates anti-prostitute bias, the heinous murders reflect an extreme version of the hatred, misogyny and dehumanization directed towards prostitutes. It may be that when violence against prostitutes gets to the point of vicious rape and or murder, the case will be taken seriously and the anti-prostitute bias will be offset by the horror of the brutality. Without trial transcripts, I cannot draw conclusions or make observations on whether there was negative or discriminatory treatment in the course of these trials. The Pamela George trial, for which Razack did have the transcript, raises the concern that deeply ingrained negative attitudes towards prostitutes might well have been in operation, even in cases where the sentence imposed was appropriately severe.

\footnotetext{
${ }^{12}$ See R. v. Peters [1992] B.C.J. 2126 (C.A) (The case of Trevor Rodney Peters. He plead guilty and received a life sentence for the murder of a sex worker, Nancy Jane Bob in 1990). See also, $R$. v. Allender [1996] B.C.J 224 (C.A) (The case involved Brian William Frederick Allender who was convicted of first degree murder. The victim, a prostitute, was killed by the accused with a propane tank which he hit her on the head with. Thereafter he removed her sexual body parts with a knife, put them in bags and threw them away).
} 
With limited resources, I was not able to locate or access other trial decisions or specific information regarding trials in Canada where the prostitute was a victim. ${ }^{13}$ Within the last few years news articles reporting on the abduction, abuse and deaths of prostitutes have not been uncommon. In fact, the headlines are unfortunately becoming more frequent. Even going back into the 1980's and 1990's, there are news articles that mention victims of violence and murder who worked as prostitutes, often referring to trials and charges. ${ }^{14}$ However, I was not able to find reported cases of these trials. There are a number of possibilities that could account for the absence of reported cases, the most obvious being that it is not always mentioned in the decision if the complainant is a prostitute. Or it may be that these cases were not considered legally noteworthy and so were not reported. Alternatively, the lack of such cases may indicate that the Pamela George and the Ms F cases are anomalies. On the other hand, the lack of cases might reflect prostitutes' reluctance to report and press charges against abusive customers or pimps and/or police officers' unwillingness to take the injuries seriously and to pursue full investigations. When the victim is a prostitute Crowns may be willing to accept guilty pleas for lesser offences or may drop charges entirely due to lack of evidence or concerns about the prostitute as a witness.

Given the absence of available data, I could not continue this direction for my thesis. I shifted my focus to information that is more readily available, that is to the government's response to violence against female sex workers, via government studies,

\footnotetext{
${ }^{13}$ I reviewed the relevant academic literature and references to cases cited in academic works. I did an independent search of media articles of online newspapers mentioning trials of accused individuals who had harmed or murdered prostitutes. I also completed a quicklaw search for reported cases.

${ }^{14}$ See for example, Sean Durkan, "Most Hooker Killers Go Free" Toronto Sun, 14 February 1997 p. 5. Reproduced online by Maggie's Toronto. Available at: http://www.walnet.org/csis/news/ottawa 97/torsun970214.html See also Jim Rankin, "Woman Working Street Corner Slain" Toronto Star, 9 March 1999. Reproduced online by Maggie's Toronto. Available at: http://www.walnet.org/csis/news/toronto 98/torstar-980309.html (accessed 26 November 2006).
} 
commissions and reports on prostitution over the last 20 to 25 years ending with the most recent report by the Subcommittee on Solicitation Laws, The Challenge of Change: A Study of Canada's Criminal Prostitution Laws released in December 2006. This Subcommittee was mandated by The Standing Committee on Justice and Human Rights, to improve the safety of the communities affected by prostitution as well as the safety of prostitutes. ${ }^{15}$ This mandate was in response to the high numbers of murdered and missing prostitutes and the attention and reaction this has garnered from women who work in the sex trade, friends, family and supporters of these women as well as the general public, law enforcement and some politicians. In examining these reports I am trying to determine the extent to which these committees and reports are informed by the violence and abuse in the lives of sex workers, the context in which the violence is framed, the seriousness with which the issue is taken up, and finally, the Government's response.

\section{Terminologies, Debates and Positions}

\section{"Sex worker" and "Prostitute"}

I refer to women who work on the streets and engage in sex for money as both "sex workers" and "prostitutes." I use the terms interchangeably. Language and labeling are laden with assumptions and multiple meanings. The choice of terms especially in this context is important. In this case it is impossible to find a common term or reference that would satisfy all women in the sex industry (although the research and literature indicate

\footnotetext{
${ }^{15}$ Report of the Subcommittee on Solicitation Laws of the Standing Committee on Justice and Human Rights, The Challenge of Change: A Study of Canada's Criminal Prostitution Laws (December 2006). Available at: http://cmte.parl.gc.ca/Content/HOC/committee/391/just/reports/rp2599932/justrp06/sslrrp06e.pdf
} 
most women are more comfortable with "sex worker"), or all women and feminists in general. I would prefer to only use the term "sex worker," however I choose not to use it exclusively, as it encompasses other forms of sex related work such as escort services, exotic dancing, adult films, and so forth. Because this thesis focuses on direct-contact sexual services, I will also use the term "prostitute" as it has been typically utilized in referring to women who engage in this type of sex work. While it would be helpful to solely use this particular term in order to distinguish from other types of work, I believe the women who sell sex on the street are "working" and I use both terms "sex worker" and "prostitute", asking the reader to keep in mind I am referring to adult women who engage in sexual activities for money on the streets.

\section{"The Prostitute" and Prostitution}

There is no universal truth about prostitution or the woman who engages in it. Each woman approaches and experiences prostitution differently. However, sex work has been divided into three categories that assist in understanding the mode of entry into this work and the conditions under which it is performed. ${ }^{16}$ The first, sexual slavery (sometimes called "forced prostitution"), usually refers to the trafficking of women and children and juvenile prostitution. Women engaged in the second type, survival sex, are often driven by circumstances such as poverty, abuse, and drug addiction and sell sex in order to survive. Lastly, sex as choice, is just that, a choice made by a woman to sell sexual services, possibly but not necessarily, as a result of economic necessity and limited job opportunities and alternatives. While I do not specifically refer to these terms

\footnotetext{
${ }^{16}$ These three categories have been developed and cited by other researchers and writers in the area of prostitution. See for example, John Lowman, "Reconvening the federal committee on prostitution law reform" (2004) 2 Canadian Medical Association Journal at 147.
} 
in the rest of my thesis, most of what I discuss applies most fully to prostitutes engaged in survival sex. They are at a greater risk of violence due to their more restrictive circumstances and the conditions in which they work.

I will be looking at adult, female street prostitutes for the purpose of my analysis. The scope of my research does not permit me to examine lesbian/gay prostitutes, transsexual and transgendered prostitutes or male prostitutes. While I recognize these groups experience violence, and may be even more vulnerable to violence, there are issues unique to them that require separate analysis. Trafficking of women and children, and minors involved in prostitution similarly warrant separate analysis. It is important to note that youth, and trafficked youth and women, exist among street level sex workers. However, the confounding of prostitution and trafficking is problematic because prostitution is seen to have some element of choice and agency, whereas trafficking, and in turn juvenile prostitution, are seen as involving coercion.

A secondary reason I do not address juvenile prostitution and trafficking specifically is because the issue of violence tends to get lost in the discussion. When we 3 talk about these two issues, we talk about "saving" youth and trafficked women and developing programs to rehabilitate and guide them. Legal reform surrounds strengthening the laws to target the exploiters and traffickers. These discussions and strategies overlook how to deal with and address the reality of violence on the streets, violence that is occurring everyday, directed at all prostitutes, regardless of how or why they are there. Categorizing sex work and sex workers helps us to better understand prostitution, its sources and its effects. But the categories are interrelated and overlap. They should not be used to distinguish the "helpless deserving women" who are seen as 
victims from those who "choose" prostitution and therefore are seen as choosing (i.e. deserving) abuse and violence.

I cannot address all aspects of prostitution and street prostitution. Prostitution is rooted in many other related issues of inequality, the feminization of poverty, patriarchy and capitalism. In the Canadian context race plays a very critical factor in the characteristics of women who work as prostitutes and their treatment by the justice system. Aboriginal women make up a large portion of women working in the sex industry, and they also make up a large portion of the murdered and missing women in Canada. ${ }^{17}$ Amnesty International's Stolen Sisters Report points out that at least a third of the more than 70 women who disappeared from Vancouver's downtown eastside were Aboriginal. ${ }^{18}$ Compared to other women in prostitution, Aboriginal women are more likely to be dealing with drug problems and extreme poverty. ${ }^{19}$ All the factors that contribute to violence and exploitation against women in the sex trade increase in the case of Aboriginal women. They are also faced with unique experiences such as racial profiling in the context of law enforcement. ${ }^{20}$ Aboriginal prostitutes are doubly marginalized when they are subjected to violence. Their identity as a prostitute and as an Aboriginal woman is reflected in their treatment by the justice system. Any proposed policy or legal reform requires full consideration of all these factors. In the context of this thesis, I acknowledge these issues but cannot engage in them fully.

My arguments and analysis will not focus on why and how women engage in prostitution. Regardless of why and how they got into prostitution, regardless of whether

\footnotetext{
${ }^{17}$ Amnesty International, Stolen Sisters: Discrimination and Violence against Indigenous Women in Canada (October 2004). Available at: http://www.amnesty.ca/stolensisters/amr2000304.pdf at 22.

${ }^{18}$ Ibid at 23.

${ }^{19}$ Ibid.

${ }^{20}$ Ibid.
} 
they wish to remain or leave, my focus will be on how we can make it safe for them to work, and what we need to do eliminate the high levels of violence they are subjected to. In framing the issue as such, my intention is to situate violence against female street prostitutes in the larger issue of violence against women in general. It will be helpful to draw parallels between violence against prostitutes and other forms of violence against women. In analyzing violence against sex workers as an issue of violence against women, I am seeking to learn what difference this insight might make in understanding violence and abuse directed at female sex workers and in turn responding to it. The treatment by government and the justice system of other victims of gendered violence may provide approaches and strategies for reform on the issue of violence against prostitutes. There is also much to be learned from previous violence against women campaigns and movements that can be applied to the present challenge to violence against sex workers.

\section{Feminist Perspectives}

Differing and strong opinions associated with prostitution and the women engaged in it have existed for as long as prostitution has. Prostitution is seen as a feminist and civil liberties issue, a law and order issue, as well as an issue of morality. ${ }^{21}$ Each of these perspectives has a distinct view of prostitution and prostitutes. Because of the gendered nature of the violence experienced by prostitutes, this violence is most significantly a violence against women issue. In this way, prostitution is clearly a feminist concern. The feminist debate surrounding prostitution consists of a myriad of

\footnotetext{
${ }^{21}$ James R. Robertson, "Prostitution," Current Issue Review 82-2E, (Ottawa: Library of Parliament, 1999). Available at: http://dsp-psd.pwgsc.gc.ca/Collection-R/LoPBdP/CIR/822-e.htm
} 
perspectives, theories and arguments. It would not be accurate to say there are only two competing perspectives, although it is generally two perspectives that dominate the discussion. There are those feminists who view prostitution as exploitation and subordination, and then there are those who view prostitution as a form of work, and a woman's right. Within these arguments there are different ways in which the women in prostitution are viewed, and different approaches that would guide political policies and legal reform (i.e. decriminalization).

While the feminist debates and theorizing on prostitution, and prostitution and violence are useful and important, the issues have and will continue to be well presented and argued. Reiterating these debates can be counterproductive in that feminists have tended to stay stuck in their positions unable to then work together on the issue of violence against prostitutes. The debates shift the focus away from what we do agree on, and that is addressing the safety of women working in the sex trade, to the many things we do not agree on. However, it is not possible to entirely avoid the debates and my own feminist perspective will be evident in my arguments and analysis. It is therefore necessary for me to situate myself on the issue.

I align myself with the pro sex feminist (also referred to as sex positive or sex radical) perspective on prostitution that acknowledges selling sex as a form work. I support this somewhat radical re-thinking of prostitution as work and would argue that the women engaged in this work are entitled to basic human rights and protections as workers. My writing and arguments are influenced by the lobbying and activism of pro sex feminist writers as well as sex workers' rights groups and organizations that advocate the right of a woman to sell sexual services on her own terms without coercion, force or 
criminal punishment, and are lobbying for change and bringing the issues that sex workers face to the forefront in Canada

I believe in the right to sexual self determination and support the argument that sex workers are best able to speak from their own experiences and therefore should have their voices heard in any potential policy and legal reforms that may take place pertaining to prostitution and to violence. That said, I do not believe in excluding other women and feminist groups who may have differing opinions and ideas pertaining to prostitution from the discussion. They too should be invited to contribute to social and legal reform and to address the issue of violence. I recognize the limitations in my own arguments and feminist perspective and also the validity and arguments of other feminists. However, I find the pro sex feminist perspective, in particular the work and advocacy on sex as work, the most persuasive, in particular because it takes into account women's agency. In addition, the strategizing and theorizing of pro sex feminists and the sex workers rights' movements around the issue of violence are a helpful lens through which to view and understand the problem, and in turn challenge it because they are speaking from their lived experiences and their efforts focus on the fact sex workers are citizens, and entitled to earn a living, free from harassment and violence.

Like most pro sex feminists I support decriminalization of prostitution because it enhances women's self determination, it minimizes the need for pimps and it does not invoke the regulatory powers of the state. ${ }^{22}$ While decriminalization is a step in the right direction for the safety, health, and rights of women engaged in sex work, we loose sight

\footnotetext{
${ }^{22}$ Maggie O'Neill, "Prostitution, Feminism and Critical Praxis: Profession Prostitution?" Umbruch Neue Sozial-Wissenschaftliche Perspektiven a special edition of the Austrian Journal of Sociology Summer 1996 at 333-332. Available at: http://www.staffs.ac.uk/schools/humanities and soc sciences/sociology/level3/prost 3 .htm
} 
of the critical issue of violence by making decriminalization our sole focus and strategy. The same criticism can be applied to those who argue for criminalization, legalization or eradication of prostitution. The focus on prostitution rather than the needs of prostitutes gets us mired in the endless pro and con debate. If we instead address the violence first, as part of an issue of violence against women and how it is manifested, permitted and treated, that may lead us to solutions, to a logic of endorsing and encouraging legal and political reform, and perhaps decriminalization of the trade. Regardless of how we view prostitution, we need to challenge the way we perceive the women involved in it. We need to see them as women, not as prostitutes. Given that women are and will continue to engage in prostitution, it must be made safer in order to make the women who work as prostitutes safer.

\section{$\underline{\text { Inherent Violence and Harm }}$}

Different terminologies are used within the discussion of prostitution which produce dual meanings and interpretations. Therefore it is necessary to clarify how I will be using particular terms. When I speak of "harm" or "violence" in the context of prostitution, I am referring to acts of physical, mental, emotional, and sexual abuse directed at prostitutes by clients, pimps, the public, and legal officials. This is not to be confused with the use of "harm" of prostitution utilized by some writers, feminists and government. Harm is sometimes used to describe the act of prostitution as harmful to the women who engage in it, on an emotional, psychological and physical level. From this perspective, prostitution is seen as degrading, dehumanizing and exploitive to the women involved, and all women in general. This is related to and tied up within the discussion below on violence. 
"Harm" is also used to describe the harm to communities, that being the effects of prostitution related activities in residential and business neighborhoods such as noise, traffic, drug litter and so forth. "Nuisance" is used interchangeably with harm by these groups and organizations to describe the effects of prostitution in public and residential areas. Harm to communities and harm to prostitutes are often addressed together. The ineffective and problematic nature of this correlation is taken up in my thesis.

There are competing ideological frameworks around "prostitution and violence." When I talk about violence and prostitution I am not equating the two, in fact I argue strongly against such an association. I see violence as separate from prostitution, a harm that is experienced by prostitutes that needs to be addressed. There are however, two views that equate violence and prostitution but in different ways. Some feminists view prostitution as a form of violence against women. From this perspective prostitution is seen as a sexist practice that is degrading and exploitive of the prostitute and women generally. Akin to rape, wife abuse, and pornography, prostitution is understood to be premised on a sexualized objectification of women that treats women as inferior and maintains women in a submissive position. This view of prostitution is in opposition to my own which views prostitution as a legitimate form of work. I do not want to get sidetracked into the debates so I choose not to engage with the description of prostitution as a form of violence against women. I focus instead on an issue that all feminists agree on - the need to reduce and eliminate acts of male violence to which prostitutes are subjected. 
Separate from this and a view of prostitution and violence that I will engage with, is the construction of prostitution as inherently violent. ${ }^{23}$ This assumption sees prostitution as a dangerous activity or profession, and sees any harms associated with the act of prostitution as "coming with the job." There are those who view the incidents of abuse, violence and harassment of sex workers, as a direct result of the dangerous nature of prostitution itself. This perspective has the effect of making prostitutes responsible or seen as responsible for their own victimization by engaging in prostitution. In the context of this thesis I refer to this position in terms of inherent violence.

\section{Overview of Chapters}

What follows in my thesis is a discussion and analysis of prostitution in Canada, and the issue of violence against prostitutes. Chapter two presents a prelude to the current situation of prostitution and the treatment of prostitutes by providing a historical background of prostitution in Britain and Canada beginning in the Victorian era. This period produced many of the views society has of prostitution and prostitutes, and also stereotypes and discriminatory laws that persist today and contribute to the abuse and violence experienced by sex workers. Chapter three documents the studies, research, and cases of incidents of violence against prostitutes. We see in this chapter that myths and stigmas that were imposed on sex workers historically have been maintained and continue to inform public attitudes toward sex workers. This chapter highlights the severity and extent of abuse and violence against sex workers, and draws parallels with other forms of violence against women. Chapters four and five describe and then critique

\footnotetext{
${ }^{23}$ For an example of this inherent violence perspective, see: the Criminal Compensations Act decision referred to supra note 10 .
} 
what the Canadian Government's response has been to this increasing violence by looking at committees and reports mandated to examine prostitution. While most of these reports were looking at other aspects of prostitution and not at the violence against prostitutes, the violence and abuse inevitably surfaced as a major concern in all of the reports. I examine the implications of this. Lastly, chapter six describes and critiques the most recent Government report on prostitution, singling out this report for special consideration as it was given the express mandate to address violence against prostitutes. My main concern in this chapter is the Government's unwillingness and failure to respond to this issue. I explore why we continue to find ourselves in a position of immobility, lack of consensus and inaction on the issue of violence against female sex workers, despite the overwhelming evidence of the severity of the problem and the urgent need for action. 


\section{Chapter Two}

\section{The History of Prostitution}

The activity and behaviour associated with prostitution, and the response of society, law enforcement and government to prostitution and the women engaged in it, arise out of a particular social, legal, political and historical climate in which violence and abuse against female street prostitutes have been implicitly condoned and fostered.

Given Canada's colonial past, the social and legal response to prostitution was influenced by events and policies in Great Britain and to a lesser extent the U.S. ${ }^{1}$ Canada's prostitution laws and the accompanying myths and stigmatization surrounding women working as prostitutes were formulated mainly in the Victorian period (1837-1901) and have persisted since that time. There has been little change in Canada's Criminal Code provisions pertaining to prostitution, from the original enactment in 1892 . The social, legal and political marginalization that prostitutes face flow from the language, interpretation and ideologies embedded in our legal system and reflected in the treatment of female sex workers by law enforcement, the public, media and government.

As current debates, literature and media coverage of sex work related issues demonstrate, prostitutes are still largely seen and responded to based on stereotypical images of the sexually promiscuous deviant or the drug addicted, exploited victim. Regardless of which of these images one may have of the prostitute, who she is and what she does have been and continue to be treated as a social/moral "problem." Hence we hear and read of "the problem of prostitution" whenever policy or legal reforms pertaining to sex work are raised. Historically, prostitution was seen as both a public

\footnotetext{
${ }^{1}$ John P.S. McLaren, "Chasing the Social Evil: Moral Fervor and the Evolution of Canada's Prostitution Laws 1867-1917" (1986) 1 Canadian Journal of Law and Society 125 at 126.
} 
nuisance and an issue of private morality, two views that have persisted in current responses to prostitution. A double standard emerged and continues. In making prostitution private, it is rendered invisible. Yet women prostitutes stand as the visible representations of this "illicit" sexual behaviour, immorality and nuisance. As such, they become the targets of scorn and blame, while the male customers and pimps remain invisible and thus immune from any perception of wrongdoing.

I begin my historical discussion with the Victorian era as it marks an important period in history with regard to women and sexuality and hence prostitution. One of the points I would like to highlight and draw out in my discussion about the history of prostitution and its relevance to prostitution today is that the dominant response to prostitution has consistently been the push for a combination of moral reform and legal repression. These negative responses have created decades of social and legal marginalization for women involved in prostitution, placing them outside the scope of "normal" society. O'Neill explains that the moral concern about acceptable female behaviour and "normal" sexual relations in conjunction with or in addition to, the perceived proper role of women in the family unit at the time, heavily influenced criminal law on prostitution. ${ }^{2}$

The effects of Victorian morality and the social purity movement, together with the social organization of gender relations, created a legacy that is now enshrined in law with very little change over the years. ${ }^{3}$ Prostitution may have been viewed and treated at times as a "necessary evil" or inevitable, however as Davis and Shaffer summarize, "In

\footnotetext{
${ }^{2}$ Maggie O'Neill, "Prostitution, Feminism and Critical Praxis: Profession Prostitution?" Umbruch Neue Sozial-Wissenschaftliche Perspektiven a special edition of the Austrian Journal of Sociology Summer 1996 at 333-332. Available at: http://www.staffs.ac.uk/schools/humanities and soc sciences/sociology/level3/prost 3 .htm ${ }^{3}$ Ibid.
} 
recorded history, no society has completely accepted it (prostitution) as a valid and integral part of the community...it is something to be abhorred or tolerated but never condoned." This attitude and treatment of prostitution and prostitutes have created an overriding legacy of hypocrisy and blame to the detriment of women working as prostitutes.

\section{The Victorian Period and Prostitution}

The Victorian period in Great Britain saw ideals of social purity and morality, contrasted with dire economic poverty for working class and underclass women involved in a prolific sex for sale market. ${ }^{5}$ This took place amongst huge hypocrisy that rendered prostitutes extremely vulnerable and marginalized. There was a demand for sex from women who were willing to provide it for money, and yet these women were treated poorly. Ideas on sex and female sexuality saw sex and sex for money as a cultural evil. Any deviation from the strict social norms in Victorian society was seen as constituting a severe lack of morals. Sex was kept behind closed doors, neither discussed nor celebrated. Anything outside conventional "Victorian lovemaking" between married partners was taboo, and in most instances considered positively harmful. ${ }^{6}$ Concern over women's virtue and the "protection" of women and children, both as property and as integral components to the family unit, emerged during this time. Therefore, while prostitution flourished during the period, it was a forbidden subject matter because of its sexual nature and deviation from sexual norms and the behavioral expectations of

\footnotetext{
${ }^{4}$ Sylvia Davis \& Martha Shaffer, Prostitution in Canada: The Invisible Menace of the Menace of Invisibility (1994). Available at: http://www.walnet.org/csis/papers/sdavis.html

${ }^{5}$ O'Neill, supra note 2.

${ }^{6}$ McLaren, supra note 1 at 153 .
} 
"respectable" women. Prostitution came to be seen as a widespread social evil and a pressing public concern. It was a moral concern for most everyone: it was a woman's rights issue and an issue of exploitation, it was a dangerous evil that lured young innocent girls into sexual slavery; and it was also an activity that threatened gender relations and the family.

The dominant perspectives and the subsequent responses to prostitution arose out of several popular perceptions and misconceptions about the women and girls who engaged in prostitution. Prostitution sparked intense reaction as it was seen to threaten the morality of the country and the well being and sanctity of 'the family.' More and more, women were seen as the guardians of the family's welfare and as representing the moral conscience of the community. ${ }^{7}$ Hence, the prostitute as the bad, promiscuous sinner contrasted greatly with Victorian ideals of the good wife, mother and daughter. The prostitute was often depicted as a hard vice ridden jade and temptress, selling her body to satisfy her appetite for sex, liquor and expenses. ${ }^{8}$ Many saw these women as seductresses who tempted decent men from their family homes, and whores who spread venereal disease. The good girl/bad girl dichotomy was imposed on prostitutes rendering them irredeemably bad.

\section{Diseased Bodies and Deviant Minds}

The medical response to prostitution is interesting because of its influence in the construction of the prostitute as "other" and in particular the myth of her being "dirty" and "diseased." An examination of $19^{\text {th }}$ century British medical discourse on women's

\footnotetext{
${ }_{8}^{7}$ McLaren, supra note 1 at 129.

${ }^{8}$ Christine Stansell, City of Women: Sex and Class in New York, 1789-1860 (New York: Random House, 1986) at 172.
} 
bodies in general and venereal disease in particular demonstrates how venereal disease was feminized and how medical literature on syphilis and gonorrhea influenced the construction of prostitutes as different from other women because they were contaminated. ${ }^{9}$ The identity of the prostitute was, and perhaps still is, tied up with her physical body. The prostitute is often seen as the diseased physical and moral body, as the suffering victim, as the working class body, as the physically abnormal body, with each of these negative images formulated in contrast to the idealized side of the female dichotomy, the respectable woman, and the respectable and pure female body. ${ }^{10}$ The historical discussion of prostitution in the medical context often associated her body and genitals as being different and diseased, as contaminating men. These myths continue to surround sex workers and their bodies today; the association of prostitutes with disease remains. Prostitutes are often labeled as carriers and spreaders of STD's and HIV and one of the current rationales for regulating and criminalizing prostitution is the regulation of HIV and STD's. ${ }^{11}$

Victorian England not only characterized the prostitute's appearance and body as different and diseased, but her mind as well. Criminologists and psychologists contributed to these negative stereotypes of the prostitute. According to Freud, some men preferred prostitutes because they could achieve sexual satisfaction with a woman

\footnotetext{
${ }_{9}^{9}$ Joanna Phoenix, Making Sense of Prostitution (Hampshire: Macmillan Press, 1999) at 29.

${ }^{10}$ Shannon Bell, Reading, Writing and Re writing the Prostitute Body (Bloomington: Indiana University Press, 1994) at 72.

${ }^{11}$ See CBC News online article "Ottawa Sex Trade Customers, You've Got Mail" 02 October 2007 available at: http://www.cbc.ca/canada/ottawa/story/2007/10/02/ot-johns-071002.html re: Ottawa Police initiative to send out letters to "clients" stopped by Police while talking to a prostitute. Among other things, the letter warns the individual of health concerns attributed to street prostitution, such as HIV and Hepatitis. This initiative blatantly attaches a "disease stigma" to women working on the street, and attempts to deter clients from engaging with prostitutes through the threat of disease.
} 
they regarded as inferior and did not love. ${ }^{12}$ Thus the prostitute became the unlovable inferior "other" intended for men's sexual gratification. Additionally the idea that prostitutes were inherently different biologically was put forth by Lombroso in 1895 when he argued that prostitution was the feminine equivalent of criminality in men. ${ }^{13}$

\section{$\underline{\text { Prostitute as Victim }}$}

Prostitute as "victim" was one of the most dominant perceptions during the Victorian period especially among feminists and women's organizations. Vocal and active feminist of the era, Josephine Butler, along with those who supported and campaigned with her, tended to view these women as "victims" rather than the alternative view of "whore and temptress." Butler and other feminists saw prostitutes as needing to be rescued, reformed and rehabilitated. They felt compassion toward these women and felt revulsion at the discriminatory treatment prostitutes received by society. However, their actions still focused on changing and "saving" the prostitute, rather than on the negative treatment of prostitutes.

At the time, a widespread ideological fervor arose based on the perception that young girls, generally from poor homes, were being kidnapped, forcibly confined in brothels and coerced into selling sexual services to middle class and wealthy men. Racism combined with sexism described what came to be known as "White slavery," the fear that girls were being trafficked, in particular by foreign and immigrant male exploiters. The fervor was fueled by the overactive imagination of journalists and by media tactics that often sensationalized what was really going on, playing on the idea that

\footnotetext{
${ }^{12}$ Cited in Vern and Bonnie Bullough, Prostitution: An Illustrated Social History (New York: Crown Publishers, 1978) at 9.

13 Cited in Joanna Phoenix, Making Sense of Prostitution (Hampshire: Macmillan Press, 1999) at 37.
} 
innocent girls were falling prey to these exploiters. This is not to say that there were not some recorded instances of girls and women being forced into prostitution, but recent reexaminations have shown that the numbers were small and that a rampant wave of young girls being kidnapped and forced into sexual slavery had not taken place. ${ }^{14}$ Research indicates that most migrants involved in prostitution, for example, were adult women prostitutes who traveled of their own accord in hopes of better working conditions. But the picture presented at the time was very different. Sensationalist journalism portrayed a vastly distorted picture of widespread female slavery which eventually supported a growing social purity crusade against prostitution. ${ }^{15}$

We see a very similar response and reaction from some feminists today, with respect to trafficking in women and children, labeled as modern day sexual slavery. A fervor over this issue has emerged with very elaborate campaigns and graphic literature documenting the horrors of this international crime. Much like the crusades against prostitution in the Victorian period, it is mainly feminist organizations, religious groups and the media that are highlighting this issue. One of the problems however, is that while we can be certain this criminal activity does exist, there are no statistics on the extent of the problem and estimates are unreliable. ${ }^{16}$ We need to also ask ourselves about the potential role that racism plays in the current hype over trafficked women, as it played in the moral panic over the white slave trade in the Victorian era. Given the increase in

\footnotetext{
${ }^{14}$ Judith Walkowitz, Prostitution and Victorian Society: Women, Class and the State (New York: Cambridge University Press, 1980).

${ }^{15}$ Gail Pheterson, The Prostitution Prism (Amsterdam: Amsterdam University Press, 1996) at 11.

${ }^{16}$ Frances T. Miko and Grace Jean-Hyun Park, "Trafficking in Women and Children: The U.S and International Response" Report for Congress (Congressional Research Service, Library of Congress, 18 March 2002) at 5.
} 
current media coverage of prostitution and the large number of murdered and missing prostitutes, the focus on trafficking may provide a racialized target for blame.

\section{Who was the Prostitute?}

An object of fascination and disgust, the prostitute in Victorian England was ingrained in public consciousness as a highly visible symbol of the social dislocation produced by the new industrial era. By the 1850 's prostitution had become the "great social evil." ${ }^{, 17}$ Consistent with the discussion above, literature on prostitution in Britain and to a lesser extent Canada, paints a particular picture of the prostitute. She was either portrayed as a young, vulnerable girl who was seduced and entrapped into prostitution or she was depicted as a money and alcohol driven "whore" stealing husbands from their wives. However, the reality of prostitution and the prostitute was very different from the one depicted. The economic and social conditions that existed in Victorian society, and the obvious demand for sexual services, created an opportunity for women to earn more money engaged in prostitution than in other traditional feminized forms of work and labour.

Studies and research show that girls and women worked as prostitutes for a variety of different reasons, ranging from poverty and lack of education, to freedom and independence from their families and other obligations. Historian Judith Walkowitz states,

They [prostitutes] were not rootless social outcasts but poor working women trying to survive in towns that offered them few employment opportunities...their move into prostitution in many ways was a rational choice, given the limited alternatives open to them. ${ }^{18}$

\footnotetext{
${ }^{17}$ Walkowitz, supra note 14 at 32 .

${ }^{18}$ Ibid at 14.
} 
Stansell also observes, "It [prostitution] was both an economic and social option, a means of self support and a way to bargain with men in a situation where a living wage was hard to come by."19 Prostitution was seen by many women as a viable source of income, even though it was certainly not accepted by Victorian society at a time when a women's place was supposed to be in the home, tending to her husband, and raising children. If any work needed to be pursued to supplement a husband's income it would be menial and low paying labour that did not compromise one's morals, values or chastity, even though it exposed these women to sexual harassment and other forms of violence against women in their employment. Walkowitz notes, "Placed in a vulnerable economic and social position, some women may have found the shorter hours and better pay of prostitution a temporary solution to their immediate difficulties.",20

While the monetary advantages may have rendered prostitution a reasonable choice for some women, in particular for young girls, historians have also noted that some prostitutes enjoyed the independence and the freedom from their family. Research conducted by Walkowitz and Stansell challenges a whole series of conventional assumptions about prostitutes that have been handed down from the Victorian period. Their research indicates that the prostitute was not always the innocent victim of middle class seduction and betrayal; nor was she a mere child drugged and entrapped into prostitution by white slavers. Instead for many women, the entry into prostitution was voluntary and gradual. ${ }^{21}$ The authors themselves note however, that this was not always the case. Just as in our present time, girls and women experience prostitution differently,

\footnotetext{
${ }^{19}$ Stansell, supra note 8 at 172 .

${ }^{20}$ Walkowitz, supra note 14 at 14.

${ }^{21}$ Ibid at 17.
} 
there were a variety of reasons for girls and women to work as prostitutes during the Victorian era as well. It is necessary in any work relating to prostitution to acknowledge the different women and their different stories, and the complexities of social and economic factors that contribute to their decision to engage in prostitution. This acknowledgement might allow us to disengage from the moral lens through which we view prostitution, and analyze it more complexly in its social context.

\section{Prostitution Law and Victorian Society: The British and Canadian Experience}

Because the enactment and enforcement of prostitution related laws were similar in Britain and Canada, and because Canada's laws were inherited and modeled after Britain's laws, I will often refer to Canada and Britain together in this context, pointing to and drawing out differences between the two countries and legal systems where they pertain. During the early Victorian period in Britain and the period of settlement in Canada in the 1800's, prostitution mainly occurred in brothels. ${ }^{22}$ Brothels were set up throughout populated cities, such as London in England, and Montreal, Toronto and Ottawa in Canada. Brothels were places where men could go to drink, gamble and engage in sexual activities with the women who worked in the brothels. Perhaps because it was indoors and mainly out of sight, local residents in the neighborhoods did not express a great deal of concern about the operation of these brothels, and law enforcement paid very little attention to what went out in these houses. It was only occasionally that citizens or businesses would complain, depending on the level of

\footnotetext{
${ }^{22}$ John Lowman, Submission to the Subcommittee on Solicitation Laws of the Standing Committee on Justice, Human Rights, Public Safety and Emergency Preparedness (2005) at 3. Available at: http://mypage.uniserve.ca/ lowman/
} 
nuisance that prostitution related activities caused such as public drunkenness or excessive noise. And much like today, law enforcement would only react when pressured to do so by residents, or as was the case later in the Victorian period, compelled by religious and political campaigners.

The earliest legislation pertaining to prostitution in both Canada and Britain grew out of general vagrancy statutes designed to remove indigents and other undesirables from the streets. ${ }^{23}$ Lower Canada was the first to enact a comprehensive statute dealing with prostitution in $1839 .{ }^{24}$ Police were authorized to apprehend "all common prostitutes or night walkers wandering in the fields, public streets or highways, not giving a satisfactory account of themselves." 25 Persons "in the habit of frequenting houses of ill fame" (brothels) could also be arrested if they failed to give a satisfactory account of themselves. ${ }^{26}$ Although the criminal law in Canada was modeled upon English precedents, Canadian law was significantly harsher in its treatment of prostitutes. In Canada if a prostitute was found in a public place, she could be punished merely for being a prostitute. Under the Canadian vagrancy provision, it was the status of being a prostitute that was unlawful whereas in Britain, English law permitted the arrest of prostitutes only when they were found wandering in public areas "and behaving in a riotous or indecent manner or annoying inhabitants or passengers." 27

Around the 1850's growing alarm over the distinction between public morality (i.e. conduct that affects or is assumed to affect other individuals and society's moral and

\footnotetext{
${ }^{23}$ Canadian Advisory Council on the Status of Women, Prostitution in Canada (Ottawa, 1984) at 7. 24 Ibid.

252 Vict. (1) (1839), c. 2 (Lower Canada), reprinted in Revised Acts and Ordinances of Lower Canada 1845 , class $\mathrm{B}$, at 163 .

26 Ibid.

275 Geo. IV (1824), c. 83 (England); and 2 \& 3 Vict. (1839), c. 47 (England).
} 
ethical standards) and private morality (i.e. the acceptability of one's individual private conduct or behaviour) and its effect on the family unit sparked an intense reaction against prostitution and a call for reform in the interest of public order, public health and most importantly, morality. ${ }^{28}$ Prostitution (and homosexuality as well) became concerns affecting "public morality" thought to threaten the sanctity of the family, normal sexual relations, and the good and proper nature of society. A "moral panic" was ignited, directed toward extinguishing the threat of prostitution. ${ }^{29}$ The nations of Britain and the relatively newly colonized Canada, began to worry that young girls (daughters) were being forced into prostitution, kidnapped into the "white slave trade", and more importantly, there was the perceived threat of husbands being tempted by "whores" and straying from the family. These concerns were lead by moral reformers and social purists and regulationists who wished to see the laws of prostitution strengthened, allegedly in favour of "protecting" women and mainly children. This "protection" of course came in the form of criminalizing women. Any anti-social activity thought to threaten the family and thus society in general had to be counteracted by a combination of firm moral instruction and stern application of the law. ${ }^{30}$

Law reform came in the form of amendments which strengthened the laws pertaining to prostitution and further criminalized prostitutes. The first and most notorious of such laws was The Contagious Diseases Act. ${ }^{31}$ It was implemented and enforced in Britain in 1864. Canada's Contagious Diseases Act was an exact duplicate of the English Act. Canada's legislation, An Act for the prevention of contagious diseases at

\footnotetext{
${ }^{28}$ McLaren, supra note 1 at 139.

${ }^{29}$ See Erich Goode, Moral Panics: The Social Construction of Deviance (Oxford, U.K: Blackwell, 1994).

${ }^{30}$ McLaren, supra note 1 at 139.

${ }^{31} 27 \& 28$ Vict. (1864), c. 85 (England).
} 
certain Military and Naval Stations in the Province was passed in 1865 by the united provinces of Upper and Lower Canada. ${ }^{32}$ The law was designed to prevent sexually transmitted diseases from contaminating men. ${ }^{33}$ However, the legislation was rarely enforced in Canada. ${ }^{34}$

In Britain where the Acts were enforced, the legislation allowed law enforcement to force any woman suspected of having a venereal disease to have mandatory checks and inspections. In this respect, prostitutes and women were seen as the sole carriers and spreaders of venereal disease. The Contagious Diseases Acts were consistent with the set of attitudes toward women, sexuality and class that permeated Victorian culture, sanctioning a double standard of sexual morality that upheld different standards of chastity for men and women and demarcating "pure" women from the "impure."35 Enforcement of these laws took away women's agency and control of their own bodies by putting them under ongoing state and medical surveillance. Women suspected of being promiscuous or unchaste were subjected to these mandatory checks regardless of whether they were prostitutes or not. Many women also noted the brutality of the doctors examining them and the painful and public nature of the examinations as humiliating, degrading, described as a form of "instrumental rape."36 In Britain, Josephine Butler and other women's groups responded to these laws with a vigorous campaign to have them rescinded. This campaign met with success when the laws were repealed in 1886.

\footnotetext{
3229 Vict. (1865), c. 8 (Province of Canada).

${ }^{33}$ Lowman, supra note 22 at 2.

${ }^{34}$ Canadian Advisory Council on the Status of Women, supra note 23 at 8 .

${ }^{35}$ Walkowitz, supra note 14 at 70 .

${ }^{36}$ Ibid at 202.
} 


\section{The Moral Reformers and Legislative Change}

The moral reformers of the Victorian era had the most influence and left the greatest impact on the legal and social climate of prostitution. Between 1867 and 1917 the body of criminal law relating to prostitution in both Britain and Canada underwent several amendments, allegedly aimed at protecting young girls and women. They grew from a small group of provisions (the vagrancy laws) directed mainly against street prostitution as a form of vagrancy, to a more complex set of provisions which purported to protect females in general from the procuring of a pimp or brothel keeper. ${ }^{37}$ In 1885 the British Parliament passed the Criminal Law Amendment Act of 1885 which was to provide the inspiration for, and much of the form of, subsequent Canadian legislation on procuring and bawdy houses, aimed at the exploiters. ${ }^{38}$ It established a series of procuring offences designed to protect young girls and women from those who might lead them into prostitution. It also raised the age of consent from thirteen to sixteen and made detaining a young girl or woman against her will in a brothel punishable by up to two years in prison. Lastly, it enabled justices of the peace to issue search warrants for premises suspected of holding girls and women against their will. ${ }^{39}$

Most feminists like Josephine Butler did not support the various amendments to the Criminal Code, as they only strengthened the laws, thereby increasing state and police control over women. Butler and other feminists sought instead to rehabilitate prostitutes. In the case of Canada, the rescue impulse of feminists and women's groups aided in establishing refuges and shelters for reformed or potential prostitutes. Girls were

\footnotetext{
${ }^{37}$ McLaren, supra note 1 at 127.

${ }^{38} 48$ \& 49 Vict. (1885), c. 69 (England).

${ }^{39}$ McLaren, supra note 1 at 127 .
} 
often referred to these institutions by the courts when they were arrested and charged under the vagrancy laws. ${ }^{40}$ This feminist response, like the criminal law response, had the effect of stigmatizing and 'othering' these girls and women as victims. Forcing them to undergo treatment and rehabilitation assumed that they had been forced into prostitution rather than chosen it as a reasonable alternative, and implied that they could not think for themselves and were in need of guidance. Ironically, this measure of forced treatment was as coercive as the assumed forced entry into prostitution which it was intended to remedy.

In the Canadian experience, municipalities responded to the pressure of reformists by passing laws in an effort to suppress prostitutes who worked in houses of prostitution (bawdy houses), as well as those who owned and ran these establishments, and the clients who frequented them. ${ }^{41}$ The Federal Government then responded in 1867. Parliament passed An Act Respecting Offences Against The Person which prohibited all persons from procuring the defilement of women under the age of 21 , by false pretenses, representations or other fraudulent means. ${ }^{42}$ That same year, An Act Respecting Vagrants was also passed which condemned all vagrants and disorderly persons to a maximum of two months imprisonment, a fifty dollar fine or both. ${ }^{43}$ Vagrants were defined to include prostitutes or night walkers, and all keepers of bawdy houses. ${ }^{44}$ As Constance Backhouse point outs, "Prostitution remained a status offence, which did not require overt activity or

\footnotetext{
${ }^{40}$ Ibid. at 133.

${ }^{41}$ Canadian Advisory Council on the Status of Women, supra note 23 at 10.

4232 \& 33 Vict. (1869), c. 20 (Canada).

$4332 \& 33$ Vict. (1869), c. 28 (Canada).

${ }^{44}$ Ibid.
} 
behaviour before conviction. In addition, the net was widening, now prostitutes could be arrested for attending public meetings or gatherings as well as being on the streets." ${ }^{, 45}$

One of the most significant individuals behind policy and reform of prostitution laws in Canada around the time of 1882 was D.A. Watt of the Montreal Society for the Protection of Girls and Young Women. For about 12 years, he waged a campaign to have the criminal law afford greater protection to women and children, being one of those people who saw prostitution as "white slavery" and a threat to respectable and innocent women and girls. ${ }^{46}$ The objectives of such reformers as D.A. Watt were to abolish the social evil by punishing exploiters and rescuing women and children from sexual exploitation in general and white slavery in particular. ${ }^{47}$ D.A. Watt saw his campaign demands met, when in 1886 the Canadian Government introduced An Act Respecting Offences Against Public Morals And Public Convenience which created several new offences including the prohibition of women under 16 years from residing in households for the purpose of "unlawful carnal knowledge"; and it was made an offence to entice a woman to a brothel for the purpose of prostitution or knowingly conceal her. Men were forbidden to seduce or have illicit connection with any woman of previously chaste character who was above the age of 12 and under the age of $16{ }^{48}$ This legislation was heavily influenced by the British legislation enacted in 1885 .

When the Canadian Criminal Code was enacted in 1892 Parliament implemented further measures in an attempt to eradicate prostitution in the form of bawdy house and procuring laws. Legislation prohibiting the defilement of women under 21 was

\footnotetext{
${ }^{45}$ Canadian Advisory Council on the Status of Women, supra note 23 at 10 .

${ }^{46}$ McLaren, supra note 1 at 135.

${ }^{47}$ Frances M. Shaver, Prostitution (2006) available at: http://www.thecanadianencyclopedia.com/index.cfm?PgNm=TCE\&Params=A1SEC826746

48 Vict. (1886), c. 157 (Canada), R.S.C. 1886 , c. 157.
} 
introduced, living on the avails of prostitution legislation was expanded, and laws were enacted to outlaw bawdy houses, bawdy house operators and procurers of women. ${ }^{49}$ Drawing from the already existing vagrancy laws in Canada, a specific vagrancy law was incorporated into the Criminal Code which deemed every woman a vagrant who "being a common prostitute or nightwalker is found in a public place and does not, when required, give a good account of herself." This law, which became known at the "vag c" law, remained in place in Canada until 1972.

\section{The Laws in Practice}

Ironically the enactment of these laws did little to assist prostitutes or end their "exploitation." Prostituting in the streets became more prevalent as a result of the bawdy house laws and police harassment increased. It was mainly females involved in prostitution who were arrested not the so called "procurers and pimps." An investigation of the records of the Toronto Gaol Register between 1840 and 1900 revealed that the majority of the people convicted under these Acts were financially impoverished, generally illiterate, frequently immigrant and overwhelmingly female. ${ }^{51}$ The major effect of the new laws from 1892 onwards was an increase in the arrest of women. What emerged in practice were repressive laws that, contrary to what the reformers may have wanted, did not protect young girls and women, but further criminalized and penalized them. While the reformers were convinced that girls and women were often led into prostitution, they were still inclined to believe that some of the blame had to be attached to class, lack of values and sexual irresponsibility. Reformers felt criminal sanctions

\footnotetext{
${ }^{49}$ Shaver, supra note 47.

${ }^{50}$ S. 164 (1) (c) Criminal Code of Canada (repealed in 1972).

${ }^{51}$ Canadian Advisory Council on the Status of Women, supra note 23 at 12.
} 
were necessary in order to show the female the error of her ways by moral guidance and reproof. $^{52}$

\section{The Problem with the Vagrancy Law}

There were many problems with the "vag c" law in Canada's Criminal Code, the key provision aimed against prostitutes. One of the most obvious issues with the law and its enforcement was its violation of basic rights and its discriminatory nature. Being a woman walking on the street should not be an activity that in and of itself warranted questioning and possible arrest. It was discriminatory because it targeted women. It was a violation of civil rights because it violated one's right to engage in the simple act of walking down the street or merely socializing on the street. Any woman could be questioned, could be harassed by police, could be arrested and charged if she was unable to provide a sufficient account of her presence on the street. Contrary to reformist and abolitionist goals, no significant decrease was made in the incidence of prostitution with the new laws in place and enforced. ${ }^{53}$ The increase in policing and arrest that coincided with the strengthening of the law resulted in displacing prostitution rather than decreasing or eradicating it. Brothels continued to be in operation but were often raided.

Crackdowns on brothels moved prostitution to the streets as the women tried to avoid being rounded up in the raids.

\footnotetext{
${ }^{52}$ McLaren, supra note at 139.

${ }^{53}$ Ibid at 151 .
} 


\section{Violence in the Victorian Era}

While it is fairly easy to document and discuss the social and legal response to prostitution in the Victorian era, it is difficult to track levels of violence against female street prostitutes during this time, and to assess what if any affect the laws and society's treatment of prostitutes may have had on their wellbeing. Even though criminal records were kept, and newspapers covered assaults, robberies and murders, there is no specific data that could provide accurate information on victims to indicate if they were prostitutes or not. However, one prominent case (the case of "Jack the Ripper") speaks to the violence that sex workers of the era faced. The example of Jack the Ripper indicates that violence against prostitutes is not a new phenomenon, that there were predatory men and serial killers who targeted women, in particular vulnerable marginalized women such as prostitutes, as far back as the Victorian Period. It is an extreme case that drew attention to what might possibly have been an invisible issue, the disposability of morally questionable women. $^{54}$

"Jack the Ripper" was a pseudonym given to the unidentified killer who murdered at least five women working as prostitutes in and around London, England starting in the latter half of 1888 . There were other violent attacks and brutal murders of women, mainly prostitutes, around this time, but these could not be conclusively linked to Jack the Ripper. ${ }^{55}$ Files kept by the Metropolitan Police show that the police investigation

\footnotetext{
${ }^{54} \mathrm{We}$ see the same extreme level of violence directed at prostitutes and the attention this violence and offender garnered in the trial and 2007 conviction of Robert Pickton for six counts of first degree murder. He still faces another 20 murder charges.

${ }^{55}$ Police files document other attacks. For example, Emma Elizabeth Smith was attacked in the Whitechapel area in 1888 , and a blunt object was inserted into her vagina, rupturing her perineum. She managed to walk home with her injuries and was taken to the hospital where she told police she was attacked by two or three men. She later died from her injuries. Cited in Stewart Evans and Donald Rumbelow, Jack the Ripper: Scotland Yard Investigates (Stroud: Sutton Publishing, 2006) at 47-50.
} 
begun in 1888 eventually came to encompass eleven separate murders from 1888 to 1891 known as the "Whitechapel Murders as they occurred in an area known as Whitechapel. ${ }^{56}$ Whether these attacks were perpetrated by one individual or more than one remains unknown. What we do know, is they were all very violent and gruesome attacks, largely against women who were prostitutes.

The most widely accepted view is that five of the victims, each one having worked as a prostitute, were murdered by one person who came to be known as "Jack the Ripper." ${ }^{57}$ All his victims were brutally murdered and mutilated. They had their throats slashed in an attempt to sever their heads, which at times he succeeded in doing. He also disemboweled several of the women and removed their breasts and uteruses. One author notes, "The mutilations showed a steady escalation of violence culminating in the killer's attempt to destroy the very womanhood of these women's bodies as he acted out his gynophobic rage. ${ }^{\prime 58}$ While theories and speculation abound over the identity of Jack the Ripper, there is no disagreement about what motivated him. He clearly had a sexual motivation and a hatred and loathing toward women. The most common and popular theory among academics is that Jack the Ripper was a professional gentleman, driven by misogyny, religious fanaticism or venereal disease, to destroy prostitutes. The majority of men considered as possible suspects had a known hatred toward prostitutes. ${ }^{59}$

Whoever Jack the Ripper was, he would have found prostitutes easy and accessible targets for a variety of reasons. They worked the streets late at night, they

\footnotetext{
${ }^{56}$ Metropolitan Police, The Enduring Mystery of Jack the Ripper. Available at: http://www.met.police.uk/history/ripper.htm (accessed 12 November 2007).

${ }^{57}$ The five victims were Mary Ann Nichols, Annie Chapman, Elizabeth Stride, Catherine Endowes, and Mary Jane Kelly. All five women earned money working as prostitutes.

${ }_{58}^{5}$ Perry L. Curtis, Jack the Ripper and the London Press (New haven: Yale University Press, 2001) at 22.

${ }^{59}$ Ibid at 28.
} 
would have been approachable, and they were social outcasts. All of these factors made them ideal "unworthy" and "disposable" women upon whom he could prey with impunity. We can assume that the murder of prostitutes occurred prior to Jack the Ripper, but the extreme nature of his attacks and the attendant media interest brought the issue to the attention of the public. There was a media frenzy once it became public knowledge that there was a potential serial killer in the London area, and once Londoners were made aware of the gruesome nature of the crimes, they took even more of an interest.

Feminists of the era raised the question of tolerance of violence towards women by men in general. As one author points out,

By collapsing the distinction between prostitutes and women at the time of the ripper murders (the murders were mainly but not exclusively of just prostitutes) feminists wrenched the point from otherwise sensationalizing public discussion that violence against women whether or not they are prostitutes is not acceptable. ${ }^{60}$

The same can be said of the current situation of violence against prostitutes in Canada today. It has been occurring for some time, but the recent details that have emerged in several high profile cases have highlighted the extremity and severity of the situation and captured the public's attention. Feminists of today, as with feminists before us, are trying to make the point that violence against prostitutes falls within the scope of violence against all women, and should be challenged as such.

\footnotetext{
${ }^{60}$ Eileen McLeod, "Prostitute's Working Conditions" in Prostitution. Roger Matthews and Maggie O'Neill eds. (Burlington: Ashgate, 2002) at 174.
} 


\section{Conclusion}

For the next 50 years or so prostitution continued with very little public comment or interest, and only a few minor amendments to the relevant laws. The pattern of enforcement that characterized the Victorian period continued, with mainly women being criminalized, charged and convicted for prostitution related offences. ${ }^{61}$ The focus remained on displacing prostitutes and thereby exercising some measure of control over the "problem." These women were seen as a nuisance to neighborhoods and a visible stain on social morality, but as long as they were kept relatively out of sight, society continued to tolerate their existence. McLaren concludes,

It is a permissible, if tentative, conclusion that the Canadian prostitution laws did little or nothing to stop exploitation of prostitutes let alone reduce the incidence of prostitution...the prostitutes remained the deviants, to be harassed when and how the law enforcement authorities willed it. ${ }^{62}$

The moral reformers and the abolitionists of the Victorian era left a legacy of negative characterizations, assumptions and opinions of prostitutes and prostitution that are still very much played out today as will be seen in the following chapter. The sexist patronizing ideologies of sex and sex work remain firmly ingrained in society and the law. This created the social, legal and political marginalization of prostitutes, and a state of discrimination and mistreatment that continues today. The overlying theme and legacy from this era is one of extreme hypocrisy and victim blaming. Prostitution was permitted and tolerated to a degree, seen as a "necessary evil" to satisfy men's sexual desires. Paradoxically, the women who provided this service were blamed for the "moral stain" that prostitution put on society, for spreading disease, for creating nuisance in the streets,

\footnotetext{
${ }^{61}$ Shaver, supra note 47.

${ }^{62}$ McLaren, supra note 1 at 152.
} 
for not maintaining their place in the home and in the marginalized workforce, and for tempting men away from their wives. This same hypocrisy is reflected in the contemporary treatment of prostitutes, exemplified by the continued discrimination, criminalization and violence they face which I document in the chapter that follows. Hand in hand with this, is the sexist assumption placed on most female victims of male violence that they are to blame, or somehow deserving of this violence. 


\section{Chapter Three}

\section{A Culture of Violence: Discrimination, Abuse, and Murder of Female Street}

\section{Prostitutes in Canada}

As history has demonstrated, violence against female street prostitutes is not a new phenomenon. However, the extreme vulnerability to violence experienced by women in the sex trade often goes unnoticed. Even though prostitution is in many ways highly visible, seen as a nuisance and as bringing harm to communities, prostitutes are "invisible" as victims of violence. Abuse, assault and even murder of prostitutes have been largely ignored. According to police reports submitted to Statistics Canada, between 1994 and 2004, 171 female prostitutes were killed; 45\% of these homicides remain unsolved. ${ }^{1}$ This chapter will present an overview of the literature, statistics, research and studies on violence against female street prostitutes in order to demonstrate the prevalence of violence in the lives of sex workers, the severity of the issue, and the factors that contribute to the violence. These contributing factors may also hinder solutions. It is important to establish at the outset that the figures and data presented, pertaining to assaults and murders of prostitutes, are more than likely considerably lower than the actual numbers, as a result of unreported cases and the unknown prostitute identity of some female murder and assault victims.

The victimization of sex workers has recently become more visible. It is difficult to accurately say what sparked the current interest and discussion regarding violence against prostitutes, but there are a number of events and factors that have likely

\footnotetext{
${ }^{1}$ Sylvain de Lèsèleuc, "Criminal Victimization in the Workplace" Canadian Centre for Justice Statistics. Catalogue no. 85F0033MIE - No. 013 (2004). Available at: http://www.statcan.ca/english/research/85F0033MIE/2007013/findings/profile.htm
} 
contributed to the increased attention and focus. My own conclusion is that a combination of activism and persistent advocacy on the part of sex workers' rights groups and sex workers themselves, as well as the work of influential researchers and writers such as John Lowman who provided in depth evidence documenting the high levels of violence and disproportionate number of murdered and missing women who worked in the sex trade, have pushed the issue of harassment and violence against sex workers into the spotlight. Combined with this, has been the increased media coverage of incidents pertaining to prostitution and violence, in particular the murdered and missing women who worked in the sex trade throughout Canada.

\section{Emerging Issue}

In recent years there has been a large number of high profile Canadian cases involving the victimization of prostitutes. The 2007 trial of convicted serial killer Robert Pickton is certainly the most well known. ${ }^{2}$ There is also the case of Donald Bakker who faces numerous charges for sexually assaulting and torturing prostitutes in the downtown eastside of Vancouver. ${ }^{3}$ The trial of Thomas George Svekla, accused of murdering two Edmonton prostitutes, is yet another disturbing case. ${ }^{4}$ Since the 1980 's, 28 women in the sex trade have gone missing in Edmonton. Edmonton Police officials have now stated that there may be a serial killer responsible for the many missing and murdered women. They are presently investigating the possibility that more than one serial killer may be

\footnotetext{
${ }^{2}$ See ongoing media coverage (1998-2008) of Robert Pickton's arrest, trial and conviction by Lindsay Kines et al. "Robert Pickton on Trial" Vancouver Sun, available at: http://www.canada.com/vancouversun/features/pickton/index.html (accessed on 29 January 2008).

3 "Bakker Gets Ten Years for Sexual Assaults" CBC News, 2 June 2005, available at: http://www.cbc.ca/canada/british-columbia/story/2005/06/02/bc bakker-sentenced20050602.html (accessed on 27 July 2007).

${ }^{4}$ See "Alberta Man Charged in Second Prostitute's Slaying" CBC News, 2 January 2007, available at: http://www.cbc.ca/canada/edmonton/story/2007/01/02/project-kare.html (accessed on 4 January 2007).
} 
responsible for as many as 11 prostitute murders. ${ }^{5}$ The 18 unsolved homicides of sex trade workers in Winnipeg have also garnered media coverage and public concern, as well as reports of murders and assaults of prostitutes in Toronto, the Niagara Region and Gatineau-Ottawa. $^{6}$

Similar examples outside Canada speak to the prevalence of violence and murder against sex workers on a more global scale. ${ }^{7}$ The investigation and subsequent trial of Peter Sutcliffe (the Yorkshire rapist) in the U.K, who between 1975 and 1980 raped and killed 13 women and left seven others for dead, is one such example. His victims were mainly prostitutes. ${ }^{8}$ More recently in the U.K, Stephen Wright was arrested and charged in the murders of five sex workers in Ipswich England. ${ }^{9}$ In the U.S there is the gruesome case of the Green River killer, a notorious serial killer. Between 1982 and 1998, he killed at least 48 women. Again, his victims were mainly prostitutes. ${ }^{10}$ These are some extreme examples; there are certainly more. The magnitude and horror of these cases have drawn public attention. These publicized incidents represent the most visible manifestations of a widespread culture of violence against sex workers. As the following

\footnotetext{
${ }^{5}$ See Karen Kleiss, "Project KARE on Trail of Serial Killers" Edmonton Journal, 26 October 2007, available at: http://www.canada.com/edmontonjournal/news/cityplus/story.html?id=fffdc998-9279-4819912e-b6972e51b5fa (accessed on 27 October 2007).

${ }^{6}$ See for example "Gatineau Park Slaying Victim Was Troubled Mother of 3" CBC News 12 December 2006, available at: http://www.cbc.ca/canada/ottawa/story/2006/12/12/gatineau-murder.html (accessed on 14 December 2006).

${ }^{7}$ Violence against sex workers is an international issue and concern in many other countries within and outside of North America, and Europe. However, this violence and abuse are experienced differently and on different levels depending on various factors within each country such as race, class, culture, and legal systems.

${ }^{8}$ See "Rapist Given Five Life Sentences" BBC News 23 July 2002, available at: http://www.bbc.co.uk/southyorkshire/news/2002/07/23/rape.shtml (accessed on 16 December 2006). ${ }^{9}$ Staff and agencies, "Man Remanded over Ipswich Murders" Guardian Unlimited, 22 December 2006, available at: http://www.guardian.co.uk/suffolkmurders/story/0,1977700,00.html (accessed on 28 December 2006).

10 "Green River Killings" The Seattle Times, 19 November 2004, available at: http://seattletimes.nwsource.com/html/greenriverkillings/ (accessed on 28 December 2006).
} 
studies, statistics and research show, violence against female street prostitutes is not only prevalent, it is deeply rooted in misogyny and inextricably related to other forms of violence against women.

This examination is mainly in the Canadian context, however it includes references to Britain and the U.S because their legal systems are similar to Canada, and these countries also experience high levels of violence against sex workers. Britain and the U.S have produced a large number of research papers and studies on violence against prostitutes that can be applied to the Canadian situation and are complementary to work that has been done in Canada. The most comprehensive research compiled in Canada on violence against female street prostitutes has been produced by Professor John Lowman, an expert in sex trade laws and violence against prostitutes. While he is not the only individual who has worked on this issue, his work has been substantial and influential, a significant portion of it commissioned by the Government of Canada. His work will be referred to extensively and much of my argument draws from and builds on his writing. In conjunction with this academic literature, the work and advocacy of prostitutes themselves and sex workers' rights organizations have contributed significantly to the literature on the issue of violence. It is particularly important to include their voices in any discussion of the violence that plagues them because they can best speak to their own experience. They are in a position, not only to describe the reality of violence in their lives and their work, but to offer a fuller understanding of this situation and to provide potential solutions. 


\section{Studies and Research Outside Canada}

Academic studies and writing focusing specifically on violence in the lives of sex workers emerged over the last ten years and in larger quantities over the past several years. Most of this research comes out of the U.S, Britain and Australia, as well as other parts of Europe. Globally speaking, Dalla et al. note that one of the eight most prevalent forms of global violence against women was identified as violence against female prostitutes. $^{11}$ Several UK studies have shown that sex workers experience high levels of violence. These findings are reflected in the day-to-day experience of those running projects for sex workers. In 2001 Hilary Kinnell of the European Network for HIV/STD Prevention in Prostitution, collated information about violence against sex workers, particularly murders. According to data she collected, approximately 60 women and girls working as prostitutes have been killed in the United Kingdom (several of whom are missing and presumed dead) since $1990 .^{12}$ She notes that this number is likely to be a considerable underestimate, since there are no publicly available statistics on murders of sex workers in the UK. Her study, and several other studies she cites, found that assault, robbery and murder most often occurred among street level sex workers. ${ }^{13}$ Kinnell concludes that these findings are immensely important because they demonstrate that it was her (the prostitute's) location of work (on the street) and not her behaviour that contributed to her victimization. ${ }^{14}$ Kinnell also found that the majority of the murders

\footnotetext{
${ }^{11}$ Rochelle Dalla et al., "You Just Give Them What They Want and Pray They Don't Kill You: Street Level Sex Workers' Reports of Victimization, Personal Resources and Coping Strategies" (2003) 9 Violence Against Women 1367 at 1367.

${ }^{12}$ Hilary Kinnell, "Murderous Clients and Indifferent Justice: Violence Against Sex Workers in the U.K" (2001) 4 Research for Sex Work. Available at: http://hcc.med.vu.nl/artikelen/kinnell.htm

${ }^{13}$ Ibid.

${ }^{14}$ Ibid.
} 
were committed by clients. ${ }^{15}$ In only 16 of the UK cases was there a murder conviction; in six cases the accused was acquitted. In half of these cases, the men had previous convictions for violence, including murder, manslaughter, rape and assault. This suggests that men who murder sex workers frequently have a past history of violence against sex workers and other women. ${ }^{16}$

In the U.S context, researcher Martin Monto came to a similar conclusion: "Prostitutes in the United States, particularly those who operate from the street are frequent victims of violence." ${ }^{17}$ He goes on to list several studies which indicate that the majority of prostitutes working the streets reported having been raped and physically assaulted during the course of their work. ${ }^{18}$ Likewise, researchers Raphael and Shapiro in their study measuring the prevalence of violence in the lives of 222 women working as prostitutes in Chicago, Illinois found high levels of such violence. Eighty two percent of their respondents reported being physically assaulted and sixty eight percent had been raped. ${ }^{19}$ Raphael and Shapiro examined over 25 recent studies, all of which established the existence of almost unimaginable levels of violence in street prostitution. ${ }^{20}$ The forms of violence these women experienced, as documented in these studies, ranged from verbal assaults, to physical acts of aggression such as slapping, punching, kicking, being threatened with rape, actual rape and other extreme acts of physical and sexual violence. $^{21}$ In a recent U.S study of almost 2000 prostitutes, followed over a 30 year

\footnotetext{
${ }^{15} \mathrm{Ibid}$

${ }^{16}$ Ibid.

${ }^{17}$ Martin A. Monto, "Female Prostitution, Customers, and Violence" (2004) 10(2) Violence against Women 160 at 161 .

${ }^{18}$ Ibid.

19 Jody Raphael \& Deborah Shapiro, "Violence in Indoor and Outdoor Prostitution .Venues" (2004) 10(2) Violence against Women 126 at 127.

${ }^{20}$ Ibid.

${ }^{21}$ Ibid at 133 .
} 
period, the most common cause of death by far was homicide. The homicide rate among active female prostitutes was 17 times higher than that of the age matched general female population. $^{22}$

\section{The Canadian Context}

With the increased recognition of violence against prostitutes, the Government of Canada has conducted several studies over the years, and commissioned researchers such as John Lowman to investigate the experiences of sex workers on the streets, as well the effect changes to Canada's Criminal Code have had on incidents of street prostitution and the levels of violence. These Canadian studies depict the Canadian situation for street prostitutes as similar to that of prostitutes in other countries. Data from the 1991 "Revised Homicide Survey" administered by the Canadian Centre for Justice Statistics which included information about the known occupation of victims, including prostitutes, showed that in 1991 and 1992, 22 known prostitutes were murdered, representing 5\% of all female murder victims aged 16 and over. ${ }^{23}$ From 1993 to 1995 , another 41 known prostitutes were murdered. ${ }^{24}$ Of the 63 prostitutes murdered from 1991 to 1995,60 were female; 50 of these women were thought to have been killed by men who introduced themselves as clients, and eight by pimps or in drug related incidents. ${ }^{25}$

In 1993 and 1994 John Lowman with Laura Fraser conducted an exploratory study in Vancouver for the Department of Justice on violence against prostitutes. This

\footnotetext{
${ }^{22}$ John J. Potterat et al., "Mortality in a Long Term Open Cohort of Prostitute Women" (2004) 159 (8) American Journal of Epidemiology at 778 at 778.

${ }^{23}$ L. Wolff, and D. Geissel, "Prostitution" Juristat, 13:4 (Ottawa: Statistics Canada, 1993) at 1.

${ }^{24}$ D. Duchesne, "Street Prostitution in Canada" Juristat, 17:2 (Ottawa: Statistics Canada, 1997) at 1.

${ }^{25}$ J. Lowman and L. Fraser, Violence Against Persons Who Prostitute: The Experience in British Columbia. Technical Report No. TR1996-14e. (Ottawa: Department of Justice Canada, 1996). Available at: http://users.uniserve.com/ lowman/
} 
was one of five regional studies commissioned to investigate the apparent increase in violence against street prostitutes after section 213 (the communicating law) of the Canadian Criminal Code was enacted. ${ }^{26}$ By every measure they developed, there was a marked increase in the levels of violence. ${ }^{27}$ This study indicated that all sex workers were more vulnerable to violence, but that street workers were the most susceptible. Most (80\%) of the prostitutes murdered in British Columbia between 1975 and 1994 worked on the streets. ${ }^{28}$

The most comprehensive studies carried out by Lowman examined data from the Canadian Centre for Justice Statistics as well as independent studies. Lowman found that between 1992 and 1998 a total of 86 prostitutes were murdered in Canada. ${ }^{29}$ The victims ranged in age from 15 to 41 ; the cause of death was most often a result of being beaten, strangled or stabbed. One of the most notable characteristics of some of these women's deaths was the extreme level of violence inflicted and what the police termed "overkill" where more force than was necessary was used to kill these women. Several victims were stabbed 30 to 40 times; one was stabbed 99 times. Three victims were mutilated and dismembered. ${ }^{30}$ The extreme nature of this violence prompted Lowman and many other researchers to label the sexual and physical violence against prostitutes as misogynist. $^{31}$

\footnotetext{
${ }^{26}$ The five regional studies are discussed and cited in chapter four of this thesis.

${ }^{27}$ J. Lowman and L. Fraser, supra note 25.

${ }^{28}$ Ibid.

${ }^{29}$ John Lowman, "Violence and the Outlaw Status of Street Prostitution in Canada" (2000) 6 (9) Violence Against Women at 987 at 987.

${ }^{30}$ Ibid at 5.

${ }^{31}$ Ibid at 19.
} 
There are many others in Canada who have compiled research and written on the topic of prostitution. ${ }^{32}$ More and more of these academics have also begun to focus on the safety and wellbeing of prostitutes, adding to the empirical evidence of abuse, discrimination and violence against prostitutes in Canada. For example, Christine Bruckert and Colette Parent of the University of Ottawa conducted a study with street level sex workers in the Ottawa-Gatineau region. Their findings support the prevalence of violence among street level sex workers. They note, "Almost all participants report having been victims of violence at the hands of their clients" 33 One sex worker they spoke with described her experience after accompanying a client to his home: "When I was at his place I was locked in for two hours with a gun to my head...I was rescued by one of his friends, because one of his friends arrived..."34 A significant number of sex workers described incidents with police, which ranged from verbal assault to abuse, to not taking reports of violence against them seriously. One woman explains how a client wouldn't let her go and began beating her and ripping her clothes. She stated "Nothing sexual, he just wanted to hurt me." ${ }^{, 35}$ Someone eventually phoned the police, and the woman, naked, bruised and bleeding, was arrested and the client was let go. ${ }^{36}$

\section{Sex Workers Working for their Safety}

In Canada, much of what we know about violence against prostitutes has been spoken and written about by sex workers themselves and the organizations and agencies that work with them. Sex workers and sex workers' rights groups have documented

\footnotetext{
${ }^{32}$ See for example the writings of E.N Larsen, F.M Shaver and D. Brock.

${ }^{33}$ Christine Bruckert \& Colette Parent, How to Respond to the Needs of Street Sex Workers in the OttawaGatineau Region (June 2006). Available at: www.francofemmes.org/aocvf under <publications> at 27.

${ }^{34}$ Ibid.

${ }^{35}$ Ibid at 28.

${ }^{36}$ Ibid.
} 
abuses and have been very vocal and influential in their advocacy campaigns and awareness-raising on the issue of violence. Maggie's, the Toronto Prostitutes' Community Service Project, started a Bad Trick Sheet in 1990. In 1992 Maggie's wrote a submission to the Police Services Board in response to internal investigations into the mistreatment of Toronto area prostitutes. In their submission, they cited 107 entries relating to assaults on prostitutes from the "bad date" and assailants list they compiled. The breakdown of assaults on prostitutes was 25 rapes, 47 other assaults, seven incidents of forcible confinement, 16 incidents involving knives and three stabbings, five gun incidents, four attempted strangulations, two incidents with hammers and three incidents involving attempts to run down women with vehicles. ${ }^{37}$

Stella, a community organization that is operated by and for sex workers in Montreal, has for the past 12 years, produced a monthly bulletin with a "Bad Trick and Assaulters list" where sex workers can report violent incidents. ${ }^{38}$ They also produce publications and reports and do advocacy work in an effort to challenge and minimize the violence experienced by sex workers in their city and nationwide. These two organizations are but a few of the many official and unofficial sex workers' rights groups that educate and advocate on behalf of sex workers. These organizations play a lead role in recording, monitoring and reporting incidents of violence against sex workers by police, clients and the public.

\footnotetext{
${ }^{37}$ Maggie's Toronto, Junger Commission Submission (1995). Available at: www.walnet.org/csis/groups/maggies/ (accessed on 20 September 2006).

${ }^{38}$ See Stella Montreal, Stella's Bulletin. Available at: http://www.chezstella.org/stella/?q=en/tools (accessed on 2 October 2007).
} 


\section{Media Coverage}

In addition to the research and studies that have been done in the area of violence against prostitutes, media coverage of related incidents has provided commentary and increased public awareness of the issue. In the late 1990's, the Toronto Sun and Toronto Star frequently reported assaults and murders of prostitutes. ${ }^{39}$ An even larger number of articles was written for these and other newspapers in the 2000's, again with coverage of incidents, but now also discussion pieces on the violence itself. ${ }^{40}$ Dan Gardner of the Ottawa Citizen did a series on street level violence in the lives of sex workers in $2002 .^{41}$ He cites the above mentioned research and statistics as well as interviews with sex workers, feminists, police officers and sex workers' rights organizations. From 2002 onward there has been a flurry of articles and coverage especially with the Pickton arrest and trial, and the missing and murdered women in Winnipeg, Edmonton, Toronto, the Niagara Region and the Ottawa-Gatineau region. ${ }^{42}$ In 2006 CBC news covered a story on the large number of murdered and missing women in Edmonton and the possibility of a serial killer being responsible. All were described by police as being prostitutes or having a "high risk lifestyle." online, or simply coming across articles in newspapers in major Canadian cities within

\footnotetext{
${ }^{39}$ See for example, Jim Rankin, "Woman Working Street Corner Slain” Toronto Star, 9 March, 1998. Reproduced online by Maggie's Toronto. Available at: http://www.walnet.org/csis/news/toronto 98/torstar-980309.html (accessed 26 November 2006).

${ }^{40}$ See for example, Estanislao Oziewicz, "Society helping Killers, Expert Says" The Globe and Mail 14 December 2006 available at: http://www theglobeandmail.com/servlet/story/LAC.20061214 (accessed on 20 December 2006). See also "Why Serial Killers Target Prostitutes" CBC News, 19 December, 2006 available at: http://www.cbc.ca/news/background/crime/targeting-prostitutes.html (accessed on 08 February 2008).

${ }^{41}$ Dan, Gardner, Courting Death: The Law Has Hounded Hookers out of Safe areàs, Part $1 \& 2$ (June 2002) available at: http://www.missingpeople.net/the law has hounded hookers-june 15, 2002.htm (accessed on 27 September 2006).

${ }^{42}$ Supra note 6 at 3.

43 "Edmonton's Murdered Women" CBC News, 19 May 2006, available at: http://www.cbc.ca/includes/printablestory.jsp (accessed on 19 May 2006).
} 
the last two to four years, provides numerous headlines relating to assaults and murders of prostitutes. A consistent picture emerges. A culture of violence against prostitutes has flourished and continues to do so.

\section{The Experience of Violence: Social and Legal Marginalization}

Sex workers experience violence as women, but as a subset of women, because of who they are and what they do. They are disproportionately objects of male violence because they are available as prey; they are seen as available for men; they are "othered"; they are seen and treated as disposable and invisible; they are legally marginalized; and violence is seen as part of the job. Their social and legal marginalization makes them more vulnerable to all forms of violence - verbal, sexual and physical violence by pimps, clients, the public and police. Criminalization contributes to sex workers' exposure to violence, albeit indirectly.

There is a clear lack of concern and willful indifference when prostitutes are victimized. Mckeganey and Barnard who engaged in case studies and first hand research with sex workers in England explain,

Perhaps because most societies define the prostitute as 'criminal', many people care little about either the violence that is committed against prostitutes or the corruption that is often associated with the enforcement of prostitution laws. ${ }^{44}$

The prostitute has and continues to be "othered." This is reflected in the treatment she receives when she engages with society and especially when she engages with the law. Most significantly, sex workers are perceived as responsible for their own victimization.

\footnotetext{
${ }^{44}$ Neil Mckeganey \& Marina Barnard, Sex Work on the Streets: Prostitutes and their Clients (Buckingham: Open University Press, 1996) at 1.
} 
Violence is seen as inherent to the job, thus seen as something prostitutes accept or even choose.

\section{The Law and Violence}

The Federal Government introduced Bill C-49 in 1985. It was intended to criminalize communicating for both prostitutes and clients. The Bill was passed, creating Section 213 (the communicating law) which made it a criminal offence for, every person in a public place or in any place open to public view to communicate or attempt to communicate with any person for the purpose of engaging in prostitution or of obtaining the sexual service of a prostitute. ${ }^{45}$

One of the most disturbing aspects of the culture of violence that persists against prostitutes in Canada is the role that the law, in particular the communicating law, plays in perpetuating the violence. Several feminists, writers and researchers argue that Canada's current legislation related to prostitution offences actually contributes to the high levels of violence against female sex workers, particularly those forced to operate on the street. John Lowman points to section 213 of the Criminal Code, the communicating law, as having played a pivotal role in creating a social and legal milieu that facilitated the homicides he uncovered. ${ }^{46}$ The enforcement of the communicating law drives prostitutes to work mainly in isolated areas, away from the protection of the police in order to avoid detection and arrest. In this way, sex workers are also forced to make their interactions with customers quick. The rushed nature of this initial contact often results in the inability of workers to make better and safer choices (i.e. agreeing or disagreeing to

\footnotetext{
${ }^{45}$ See Appendix - Criminal Code.

${ }^{46}$ John Lowman, Submission to the Subcommittee on Solicitation Laws of the Standing Committee on Justice, Human Rights, Public Safety and Emergency Preparedness (2005) at 6. Available at: http://mypage.uniserve.ca/ lowman/
} 
use of condoms) and in particular to assess their own personal safety and their feeling or instinct about the client.

Lowman refers to the homicide rate in British Columbia to support his connection between the prostitution laws and the deaths of prostitutes. The sex worker homicide rate from 1960 to 1999 based on RCMP files, Vancouver Police Department records, and articles in the Vancouver Sun, presents a disturbing picture. There were no murders of prostitutes reported from 1960 to1974. However, as the years went on, murders were reported with the most dramatic increase in murders occurring in 1985 with the enactment of the communicating law. There were eight murders between 1980 and 1984 and 22 from 1985 to1989. There were at least 50 from 1995 to $1999 .{ }^{47}$ Higher reporting and discovery rates may have affected the increase in numbers. However, what this might indicate is that Canadian prostitution laws put sex workers at greater risk. The number of murders increased after the implementation of the communicating law, and the numbers have continued to rise with its ongoing enforcement. A limitation of this particular analysis is that it only looks at Vancouver. A more inclusionary analysis involving other cities, in particular cities such as Montreal, Toronto, and Edmonton that have high populations of sex workers, would give a more accurate and fuller account.

The emphasis in legislative and policy reform relating to prostitution has been on the "public harm" and alleviating the public nuisance that street prostitution is seen to present, not taking into the account the wellbeing, safety and livelihood, both economically and quite literally, of the women who work on the streets. The communicating law enacted in 1985 can be understood as a continued endorsement of criminalization of the sex trade, and in turn of the women who work in it. While it could

${ }^{47}$ Lowman, supra note 29 at 990. 
be argued that violence towards prostitutes is neither encouraged nor condoned by the Criminal Code and that inappropriate enforcement is not a direct result of the legislation itself, the Criminal Code prostitution provisions by their very existence, promote the belief that prostitutes are outside the normal scope of society. ${ }^{48}$ The intent may not have been to further endanger sex workers but that has been the result. Section 213 increases the vulnerability of prostitutes and worsens their working conditions. ${ }^{49}$

Sections 210 and 211 (Bawdy House offences) effectively make it impossible for prostitutes to work out of a home or hotel..$^{50}$ Once on the street, the criminal law through section 213 punishes them for being there. Prostitutes are constantly trying to avoid police detection in order to avoid arrest and ultimately a criminal record. If prostitutes are arrested in one particular area, they are driven to frequent another location. To avoid detection, they venture to areas where there is little chance of being seen, that is run down isolated industrial areas that are usually poorly lit. Street prostitutes are being driven into areas where they are much more vulnerable to violence. No one can see or hear them if they are being assaulted or raped, and serial killers are able to target them more easily. ${ }^{51}$

Prostitutes are in a catch-22 situation, unable to turn to police for protection because police see their job as arresting, not supporting prostitutes. The relationship between prostitutes and police is usually an adversarial one. It is difficult for prostitutes to turn to law enforcement when they are assaulted or victimized for fear of being arrested or charged. Police officers are not seen to take violence against prostitutes seriously. Most of the officers Lowman spoke with were adamant that police do not

\footnotetext{
${ }^{48}$ Sylvia Davis \& Martha Shaffer, Prostitution in Canada: The Invisible Menace of the Menace of Invisibility (1994). Available at: http://www.walnet.org/csis/papers/sdavis.html

${ }^{49}$ Ibid.

${ }^{50}$ See Appendix for Criminal Code Bawdy House provisions.

${ }^{51}$ Lowman, supra note 25.
} 
classify a person's worth by what they do for a living. ${ }^{52}$ However, other research and writing (in particular, accounts provided by sex workers themselves) indicate a contrary picture. One participant in a U.S study lamented, "Society and law enforcement consider a prostitute getting raped or beaten as something she deserves, it goes along with the lifestyle." ${ }^{, 53}$ In Toronto, Maggie's documented numerous incidents of police either engaging in verbal and physical abuse of prostitutes, or condoning it. In one incident, a street prostitute was beaten, chocked with a rope and left unconscious in a dark alley. She had severe bruising on her neck and face. When she went to the police to report the incident they asked her what she expected in her line of work and refused to take the report. $^{54}$ This precarious relationship with police echoes the experiences of battered women, who were often unable to seek help and protection, as law enforcement was unwilling to intervene in domestic disputes. Battered women, like sex workers, were treated as less worthy of protection by police. It was assumed that battered women chose or were to blame for the abuse inflicted upon them by their male partners.

The Prostitute Identity and Violence: Myths and Misperceptions

A central component of the abuse and violence that persist against female street prostitutes is the way they are perceived mentally, morally, and even physically. What has happened, as is the case with many marginalized groups and individuals, is a process of "othering." 55 This process of "othering" produces a particular category, "the

\footnotetext{
${ }^{52}$ Ibid.

${ }^{53}$ Dalla et al., supra note 11 at 1369.

${ }_{55}^{54}$ Davis \& Shaffer, supra note 48.

55 'Othering' is a way of positively defining one's own identity and group by stigmatizing the "other." Theorists have used the concept of "othering" in examining the ways in which certain groups, races and cultures are categorically 'othered.' In feminist theory, see the writings of Simone de Beauvoir, Le Deuxième Sexe (The Second Sex) (1949); Judith Butler, Gender Trouble: Feminism and the Subversion of
} 
prostitute", who embodies a deviant sexuality and does not conform to acceptable female behaviour either physically or psychologically. Given this picture of moral and political marginalization, men are easily able to rationalize violence against prostitutes. ${ }^{56}$ And sharing this view, society is less sympathetic to the victims of such violence, tolerating a significant level of violence against prostitutes because of their perceived second class citizenship and because the violence is seen as part of their chosen lifestyle.

Perceptions of the female body of the prostitute reflect and fuel myths and stereotypes. She is 'othered' in the physical context as well. In addition to the traditional beliefs developed during the Victorian era that still prevail of the prostitute as diseased, dirty and different, the image of the prostitute's body is also seen as "open", in the sense of being "fair game" to unwanted acts of sexual and physical touching. Her body is no longer seen as her property; she is seen as not having the power or right to refuse sex. The prostitute's physical appearance in her manner of dress, is also stereotyped. She is often portrayed as the woman who wears a short skirt, high heels, tight shirts with cleavage and lots of makeup. This is exemplified when a woman who shows more skin than is socially acceptable is labeled a whore or prostitute. These are words in our culture that are used to denote indiscriminate sexual availability. Dress and appearance are read and judged as sexual invitation. ${ }^{57}$

The most problematic myth associated with prostitution is that women who work in the sex trade who are victims of violence somehow deserved it. Danger and violence

Identity (1990); and specifically Shannon Bell, Reading, Writing and Rewriting the Prostitute Body (1994); and Julia O'Connell Davidson, Prostitution, Power and Freedom (1990) on othering and prostitutes. ${ }_{57}^{56}$ Lowman, supra note 25.

${ }^{57}$ This is demonstrated through the example of a conviction of a woman in a Copenhagen court for soliciting in a public place, based on a policeman's testimony that he determined her intention from her walk. Cited in Nancy Henley, Body Politics: Power Sex and Non Verbal Communication (Englewood Cliffs, N.J: Prentice-Hall, 1977) at 1. 
are seen as "coming with the job." Prostitution is often referred to as one of the most dangerous forms of work. Statistics Canada perpetuates this myth. Data from the Homicide Survey in 2006 noted that homicides are often associated with a victim's involvement in illegal "occupations" such as prostitution. ${ }^{58}$ While the evidence speaks to the very real dangers of prostitution, it is extremely problematic that the sex trade has come to be seen as inherently violent. This assumption allows the violence to be dismissed as "natural." Prostitutes are seen as choosing to engage in violent work, it is seen as their choice, and their problem. The history of prostitution is repeating itself with this form of "victim blaming." As chapter two outlined, it was the women who worked as prostitutes that were blamed and seen as responsible for the social and moral denigration of society and the family. They were also seen as deserving and bringing upon themselves any ills that befell them.

This victim blaming attitude is similarly characteristic of responses to other forms of violence against women, in particular domestic violence. For a long time women have been blamed for the violence and abuse they received at the hands of their male partners. Victims of domestic violence are also blamed for staying with their violent partners. Women who remain in abusive relationships are seen as choosing to live in violence, therefore it is their problem, not the laws or society's. Women who have been raped have similarly been blamed - for seductive clothing, for accepting male invitations, for not clearly saying no, for not saying yes. Blaming the victim has been an integral component of attitudes toward violence against women. Feminists have been fighting to shift the blame from the victim to the offender on many violence against women issues. The same analysis needs to be applied to violence against prostitutes.

${ }^{58}$ Orest Fedorowycz, "Homicide in Canada" Juristat 18:12 (Ottawa: Statistics Canada, 1997) at 10. 


\section{Discourse of Disposal}

There has been a clear lack of action and attention to incidents of violence when female prostitutes are involved. Several of the studies mentioned in this chapter listed very low clearance rates and prosecutions of perpetrators. Law enforcement officials are hesitant to take violence against prostitutes seriously. In the 1990's when a large number of women went missing from the downtown Vancouver Eastside, law enforcement and the community were instead focused on a burglar who was robbing neighborhood garages. A $\$ 100,000$ reward was offered. Many women and sex workers' organizations demanded that something be done about the disappearance of the women but municipal authorities and the mayor refused to acknowledge the severity of these disappearances or offer a similar reward. ${ }^{59}$ Advocates working on behalf of female street prostitutes in Vancouver took 67 pairs of shoes and dropped them on the steps of City Hall to represent the women who had been murdered in the sex trade. As one advocate explained, "It was a symbolic gesture of being treated as society's throwaways." 60

This notion of prostitutes as "throwaway people" relates to an important aspect of John Lowman's work. He discusses what he terms "the discourse of disposal" employed by media and politicians. He relates the escalating murder rates of sex workers as having coincided with increasing anti-prostitution campaigns and hostile public attitudes. ${ }^{61}$ Resident groups began emerging in various cities where street prostitution was a "problem." Most of these organizations wanted to see prostitution removed from their neighborhoods often at any cost. In one alarming example of vigilante action, a lobby

\footnotetext{
${ }^{59}$ Lowman, supra note 29 at 996.

${ }^{60}$ Ibid.

${ }^{61}$ Ibid at 1000 .
} 
group in Vancouver wrote a letter to then mayor of Carmel California, Clint Eastwood, on behalf of the Mount Pleasant community. They described their community as being invaded by "prostitutes and criminals" and asked Eastwood to run for mayor there. The letter stated, "Talent such as yours is in great demand...PS Bring your gun." ${ }^{, 2}$ Such blatant language and calls for vigilante action condone violence against prostitutes, in fact encourage it, operating on the assumption that these women, are not worthy of any rights or protection. This discourse of disposal supports, even promotes, the violence to which prostitutes are subjected

\section{The Female Identity and Male Violence}

\section{Violence against Prostitutes and Violence against Women}

The scope of my research does not permit me to engage fully in the violence against women literature or to fully contextualize violence against prostitutes within this larger framework. Prostitutes as a particularly and specifically marginalized group of women have unique vulnerabilities, but they also share much with other victims of violence. The parallels between the historic treatment of victims of domestic abuse and sexual assault for example, and the treatment of sex workers when they are victimized, provide insight into the current situation of sex workers and possible strategies to address and reduce the violence. Such an analysis forces us to see prostitutes as more than what they do, as women subject to the sexism and misogyny endemic to our culture. It may also assist us in addressing the issue, to see it as one of violence against a particular group of women. The significance of this analytical integration is that it helps us to understand

\footnotetext{
${ }^{62}$ Ibid at 999.
} 
violence against sex workers as a serious social problem and to understand the particular vulnerabilities and issues for sex workers as well as social and legal responses to the violence.

The United Nations Declaration on the Elimination of Violence against Women defines violence against women as,

Any act of gender-based violence that results in, or is likely to result in, physical, sexual or mental harm or suffering to women, including threats of such acts, coercion or arbitrary deprivation of liberty, whether occurring in public or in private life. $^{63}$

This definition encompasses, inter alia, physical, sexual and psychological violence occurring in the family and in the general community, including battering, sexual abuse of children, dowry-related violence, rape, female genital mutilation and other traditional practices harmful to women, non-spousal violence and violence related to exploitation, sexual harassment and intimidation at work, in educational institutions and elsewhere, and violence perpetrated or condoned by the state. ${ }^{64}$ Violence against sex workers is clearly a form of violence against women. The fact that violence is perpetrated against sex workers in the context of the work they do makes it a particularly virulent form of violence against women.

Maggie O'Neill who has studied violence against street prostitutes has concluded, "Male violence against prostitutes is about the power of men, that is men exercising their control over women, taking out sexual frustrations and the enactment of

\footnotetext{
${ }^{63}$ United Nations General Assembly, The Declaration on the Elimination of Violence Against Women. (20 December 1993). Available at: http://www.unhchr.ch/huridocda/huridoca.nsf/(Symbol)/A.RES.48.104.En ${ }^{64}$ Ibid.
} 
male perversions. ${ }^{165}$ Similar arguments are made about rape and wife abuse.

Domination, power and control underlie intimate partner violence. Violence can also be a response to a man's feelings of powerlessness and inability to accept rejection. It has also been argued that rape, in particular, represents fulfillment of sexual needs through violence. ${ }^{66}$ Men may even feel entitled to act out such aggression on sex workers because they are paying for a "service" and may see prostitutes as deserving victims. Society has labeled and treated prostitutes as bad and immoral, giving some men permission to play out an extreme version of this denigration by abusing and murdering prostitutes. In a similar vein, batterers often excuse their violence by pointing to their wives "unwifely" behaviour as their justification. ${ }^{67}$ Historically a man could argue provocation in defense of murdering his wife and attribute his actions to her behaviour, something she did or said, usually something associated with her infidelity, her being unchaste, or insubordinate. ${ }^{68}$ Similar arguments are made about men who abuse and murder prostitutes. They may point to a prostitute's identity and equate her behaviour with sexual promiscuity and being "unlady" like, that is deserving of mistreatment. In the purchase of a prostitute's services, she is seen to become the property of the client and like the abusive husband, the client feels entitled to rape and abuse her.

The history of violence against women generally has been a history of social complacency. From a historical and legal perspective, the law's stance on violence

\footnotetext{
${ }^{65}$ Maggie O'Neill, "Researching Prostitution and Violence: Towards a Feminist Praxis" in Women, Violence and Male Power: Feminist Activism, Research and Practice. Hester et al. eds. (Philadelphia: Open University Press, 1996) 130 at 141.

${ }^{66}$ Nancy A Crowell \& Ann W Burgess, Understanding Violence against Women (Washington D.C: National Academy Press, 1996) at 59.

${ }^{67}$ Ibid.

${ }^{68}$ Elizabeth Sheey, "Legal Responses to Violence Against Women" in Violence Against Women: New Canadian Perspectives, Katherine M.J. McKenna and June Larkin eds. (Toronto: Inanna Publications and Education, 2002) 473 at 476.
} 
against women has been discriminatory, unjust and unacceptable. In the past the law tolerated the rape and abuse of wives it as long as the violence was not excessive. ${ }^{69}$ As Justice Wilson stated, “The law historically sanctioned the abuse of women within marriage as an aspect of the husband's ownership of his wife and his right to chastise her."70 Twenty years ago violence against women in the home was regarded as a private "family matter.,"71 It was the efforts by feminists, women, and women's groups in the 1970 's and 1980's that brought the issue of wife battering to public attention, through politicizing the issue. Changes to the law and police and charging policies followed. ${ }^{72}$ It took years of unrelenting advocacy by women's organizations and battered women themselves to force the law to recognize and respond to the violence against women as crimes.

One of the main obstacles encountered by the battered women's movement has been the unresponsiveness of the criminal justice system. As has been the case with prostitutes, the criminal justice system failed to protect the victim and refused to take action against male perpetrators. Police did not usually arrest men for assaulting their wives, rarely offered assistance to women, and sometimes denigrated them for seeking protection from the law. ${ }^{73}$ Women were perceived to be responsible for their abuse and victimization, to have done something to deserve it. We see this same ideology and sexist assumptions at play in the response to sex workers when they are victimized. ${ }^{74}$

\footnotetext{
${ }^{69}$ Ibid at 474 .

70 Ibid.

${ }^{71}$ Canadian Advisory Council on the Status of Women, Assessing Violence against Women, a Statistical Profile (Ottawa: Status of Women Canada, 2002).

${ }^{72}$ N. Zoe Hilton "One in ten: the struggle and disempowerment of the battered women's movement" (1989) 7 Canadian Journal of Family Law 313 at 314.

${ }^{73}$ R. Emerson Dobash \& Russell P. Dobash, Rethinking Violence Against Women (Oaks, California: Sage Publications, 1998) at 146.

${ }^{74}$ See my brief discussion of the Pamela George case in Chapter One of this thesis at 4.
} 
The issue of consent has been a major subject in Canada's rape laws.

Historically, wives were assumed to consent to sexual activity with their husbands, simply through marriage. The patriarchal basis of marriage was protected when husbands had unlimited sexual access to their wives. A man was presumed to have some right of property over his wife's body hence, martial rape was not recognized. ${ }^{75}$ It was not until 1983 that Canada's rape laws were broadened for the first time, making it a criminal offence for a man to rape his wife. ${ }^{76}$ More generally, women were presumed to consent to sexual activity by way of their mannerisms, their dress, or their behaviour, as well as their previous sexual history. Women bringing rape charges to the justice system faced dismissive police officers and discriminatory practices in the courtroom such as the use of their sexual history to attack their credibility, and evidentiary rules of corroboration and recent complaint combined with a broad interpretation of "consent" employed by judges. Feminists and violence against women advocates have fought hard in the courts and in the legislature to get these sexist practices eliminated. ${ }^{77}$ While discriminatory vestiges still remain, the situation currently has significantly improved for many victims of violence against women. But not so yet, for prostitutes who are raped and abused.

The challenges faced by any woman who has been raped, multiply dramatically when she is a woman who sells sex. The myth that a prostitute could not be raped was a prevalent one, and an assumption that some still have today. There is a widespread belief that by virtue of being a prostitute, the woman consents to sexual activity at all times and

\footnotetext{
${ }^{75}$ Kwong-leung Tang, "Rape Law Reform in Canada: The Success and Limits of Legislation" (1998) 42(3) International Journal of Offender Therapy and Comparative Criminology at 259.

${ }^{76}$ ibid.

${ }^{77}$ See Sheila McIntyre, "Tracking and resisting backlash against equality gains in sexual offence law" (2000) 20(3) Canadian Woman Studies 72-83. See also Elizabeth Sheehy, "From women's duty to resist to men's duty to ask: how far have we come?" (2000) 20(3) Canadian Woman Studies 98-104.
} 
with any man. Where there is consent there is no rape and the other abuses that accompany the sex are simply what she is being paid for, what she has consented to. The double victimization experienced by many women who have been raped is experienced profoundly by any prostitute who has been raped and then turns to the criminal justice system for redress. They are victimized first by the men who assault them and who think they are entitled to assault them, and second, by a society and a justice system that make the prostitute feel that she is responsible for her own victimization and force her to defend her credibility because she is seen as sexually promiscuous and to have consented to violence and to rape because she is a prostitute.

Victims' decisions to report or to not report the violence to police or to social services depend on a variety of factors, some of which include fear of the offender, shame and embarrassment, and regional availability of services. ${ }^{78}$ According to data collected by Statistics Canada, the majority of victims of spousal assault and over $90 \%$ of sexual assault victims do not seek support from the criminal justice system. ${ }^{79}$ The percentage is undoubtedly higher for prostitutes who have been raped or abused. Even with organizations like Maggie's in Toronto or Stella in Montreal where prostitutes may feel safer reporting abuses, sex workers are often still hesitant to report assaults and rapes. Workers at Stella note that prostitutes rarely denounce violence by their aggressors because their harassment is rarely taken seriously by the authorities. ${ }^{80}$ Incidents against sex workers are underreported for many of the same reasons that domestic abuse and sexual assault are underreported. Prostitutes are very hesitant to

\footnotetext{
${ }^{78}$ Holly Johnson, Measuring Violence against Women: Statistical Trends. Statistics Canada, 2006, available at: http://www.statcan.ca/english/research/85-570-XIE/85-570-XIE2006001.htm ${ }^{79}$ Ibid.

${ }^{80}$ See Stella Montreal, Press Releases. Available at: http://www.chezstella.org/stella/?q=en $/ \mathrm{medias}$ (accessed on 21 September 2007).
} 
report abuse and assault to the police for fear of not being believed, or for fear of being arrested or possibly charged, particularly if they have a warrant or were engaged with the law previously. The current police practice of dual charging in the context of domestic assault cases, that is charging the woman who reports the abuse as well as the man, is similarly having a negative impact on reporting rates of female partner abuse. ${ }^{81}$ According to law enforcement, if there is a crime then both are perceived as responsible the abused woman and her partner and similarly, the prostitute and her client.

\section{The Privatization of Violence}

The public/private divide created a barrier for battered women seeking justice.

Domestic abuse has been seen as a private matter within families and the state has been hesitant to intervene in the "home life" of its citizens. Inaction by the law and government in these matters maintained the boundary between public and private in the area of intimate violence against women. ${ }^{82}$ As discussed in chapter two of this thesis, historically, prostitution itself came to be seen as private, in particular a matter of "private morality." This privatization and effort at keeping prostitution and prostitutes "invisible" continue today. In this way, violence against sex workers is also privatized, because it is "out of sight, out of mind." Since the violence is specifically targeted it is thought not to affect "us" as a society directly. Prostitution is seen as the commercialization of sex, an act generally considered "private." As a society we are not comfortable with this commercialization, and that discomfort has forced prostitution into the secret, private

\footnotetext{
${ }^{81}$ See Michele Landsberg, "Spousal abuse sparks backlash against victims" Toronto Star, 6 July 2003 p. A02. See also Catherine Whitnall, "Where the lines blur between victim and attacker" Kawartha Lakes This Week, 24 January 2008 p. 1.

${ }^{82}$ Dobash \& Dobah, supra note 73 at 90.
} 
realm of deviant sexuality, thereby rendering the violence that occurs against prostitutes invisible.

In order to make the issue public, prostitutes themselves and associated prostitutes' rights groups have begun organizing and becoming vocal especially within the last ten years or so, about the endemic violence against sex workers. In the early 1970 's the battered women's movement put the issue of physical and sexual abuse of women and girls firmly on the social agenda and called for state intervention; ${ }^{83}$ prostitutes' organizations are now doing the same with respect to the physical and sexual abuse of sex workers.

\section{A Combination of Factors}

As a woman and a 'othered' woman, the prostitute lives and works in a society where she is socially and legally marginalized. She is put in a position that makes her susceptible to harassment, abuse and murder, and she is held responsible for her own victimization. Canada's prostitution laws literally place prostitutes in vulnerable positions and situations and then law enforcement turns its back on prostitutes when they are assaulted or abused. The statistics and studies discussed in this chapter present a clear issue of violence against sex workers. Prostitutes regularly experience emotional and physical harassment, abuse and rape. In the most extreme of cases, they are tortured and murdered.

Even though the issue of abuse and violence in the lives of street level sex workers has only recently received significant attention in the media and among the public, the problem has been evidenced in reports and committees commissioned by the

\footnotetext{
${ }^{83}$ Ibid at 2.
} 
Federal Government of Canada dating back into the 1980's. This is critical given that the Government has been presented with evidence and information for several decades now, that points to a culture of violence towards female street level sex workers. The following chapter outlines three important committees and their subsequent reports on prostitution in Canada. The approaches to prostitution evident in these reports, conveys a great deal about the treatment of women who work as prostitutes, and in turn, the response when they are victims of violence. While these committees were mandated to examine prostitution generally, or specific aspects of it, evidence of discrimination, harassment, abuse and violence were uncovered in their research. This knowledge and information is continually overlooked and ignored by the Government, as they follow a pattern of inaction on the issue of violence against female prostitutes. 


\section{Chapter Four}

\section{Reports on the "Prostitution Problem"}

Before 1975, very little had been researched, written about or recorded in newspapers regarding prostitution in Canada. However, after 1975, the number of news reports increased dramatically, and prostitution reemerged as a "social problem." The reemergence of the prostitution debates during the late 1970's and 1980's has been attributed to citizens noticing an increased visibility of women working on the streets in their neighborhoods. John Lowman notes that it appears substantial increases in street prostitution began to occur during the 1970's and into the 1980's as a result of the crackdown on brothels, especially in major cities such as Vancouver and Toronto. ${ }^{2}$ This moved prostitution onto the streets. While citizen and neighborhood groups became more aware of street prostitution and more vocal in their demand for Government to take action, other groups mainly feminist and women's organizations, pushed for action for different reasons. At that time, feminist concerns with prostitution were mainly based on a belief that prostitution epitomized male oppression and exploitation of women and that its heightened presence on the streets highlighted the plight of these women and the economic and social inequality that was driving women there. From a different womencentered perspective, the 1970's and 1980's saw the emergence of sex work discourse and the self organization of prostitutes into prostitutes' rights groups. ${ }^{3}$ These groups of individuals, along with civil liberties activists, were voicing relatively new and radical

\footnotetext{
${ }^{1}$ John Lowman, Submission to the Subcommittee on Solicitation Laws of the Standing Committee on Justice, Human Rights, Public Safety and Emergency Preparedness (2005). Available at: http://24.85.225.7/lowman prostitution/

${ }^{2}$ Ibid.

${ }^{3}$ Gregor Gall, "The Unionization of Sex Workers" (March 2004) 13 Frontline. Available at: http://www.redflag.org.uk/frontline/13/13sexwork.html (accessed 13 July 2007).
} 
claims supporting a prostitute's right to "work." In addition, law enforcement also had an interest in the debates as they were responsible for enforcing the laws related to street prostitution. Failures to address or eliminate prostitution were often ascribed to failures in the law or law enforcement.

This fractious social climate, with different sectors of society having varying and divergent concerns, pushed prostitution onto the Canadian political agenda. As public and police alarm grew in major Canadian cities in the 1980's, so too did academic and Government interest in the subject. ${ }^{4}$ This period of renewed interest in prostitution gave rise to changes in the law, and to ongoing debate and controversy surrounding law reform efforts. Over a 15 year period, the Government repeatedly commissioned studies and reports on the issue of prostitution. This chapter provides a description of the Badgley Report, the Fraser Report and the work of the Federal/Provincial/Territorial Working Group on Prostitution. While there have been additional reports on prostitution over the years, these were the main committees and reports commissioned by the Government of Canada to investigate prostitution and associated issues. The next chapter will critique these reports as well as the Government's response to these reports. My central focus in examining these reports is on whether or not any of their approaches involved a serious discussion of the violence that plagues prostitutes. This will lead into my main inquiry which looks at the response of the Canadian Government to the high levels of violence against female street prostitutes.

\footnotetext{
${ }^{4}$ John Lowman, "Canada" in Prostitution: An International Handbook on Trends, Problems and Policies. Nanette J. Davis ed. (Westport: Greenwood Press, 1993) at 57.
} 


\section{Committee on Sexual Offences against Children and Youth - The Badgley Report}

As prostitution was starting to become a concern, pornography and the sexual exploitation of youth and children had already captured the attention of Canadians and politicians in the 1980's. These concerns gave rise to the creation of the Badgley Committee in 1980 , set up to examine the incidence and prevalence of sexual offences against children and youth and to recommend improvements in laws for the protection of young persons from sexual abuse and exploitation. ${ }^{5}$ The Committee was also asked to examine the problems of juvenile prostitution and the exploitation of young persons for pornographic purposes. ${ }^{6}$ The establishment of the Committee by the Minister of Justice coincided with proposed changes to Canada's sexual assault laws. There was growing concern at this time about the high number of children who were victims of sexual offences and also the number of children involved in street prostitution. Thus prostitution was one of the issues to be addressed by the Committee, even though this was not its primary concern.

At the outset the Report notes "The issue of prostitution in Canada, in particular, juvenile prostitution, is clothed with ambiguity, myths and hypocrisy."7 Hence, the Badgley Committee, it could be argued, was a first attempt by the Canadian Government to shed some light on prostitution and on the young men and women who worked as prostitutes. To the extent that the Badgley Committee looked at prostitution, it was youth prostitution, viewed as a form of sexual exploitation. Given my focus on street prostitution, I will not delve into a great deal of detail about the Badgley Report. My

\footnotetext{
${ }^{5}$ Sexual Offences against Children: Report of the Special Committee on Special Offences against Children and Youth (Ottawa: Supply and Services Canada, 1985) at 1.

${ }^{6}$ Ibid.

${ }^{7}$ Ibid at 947 .
} 
purpose here is to acknowledge it as an introductory Report that provided some information and insight into the world of prostitution in Canada and to draw out that limited information, looking for any discussion relating to violence against prostitutes.

The main component of the research on prostitution carried out by the Committee was a survey of 229 juvenile prostitutes. Of those 229 individuals, 145 (63.3\%) were females, indicating as most studies and research demonstrate, that prostitution is a female dominated occupation. ${ }^{8}$ The Badgley Report notes high rates and incidents of abuse among the prostitutes surveyed and concludes, "life on the downtown streets of major Canadian cities involves much violence. ${ }^{99}$ In terms of pimp violence, approximately two thirds (55) of the girls indicated they were under the control of pimps; 44 of those girls indicated that they had been abused by their pimps. The girls described having been subjected to such acts as being slapped, suffering bruises and broken bones, cuts, being strangled, being assaulted with weapons such as knives and baseballs bats and being raped. The girls were also asked about incidents of violence involving other girls and pimps that they had either heard of or had witnessed. One hundred and thirteen of the 145 girls listed incidents which they had heard of involving a prostitute and her pimp. Their replies included murder, beatings, rapes, and being forcibly injected with drugs resulting in death. ${ }^{10}$

Overall the Committee found that two-thirds (63.3\%) of the youths had been physically assaulted or worse while working on the street, and that girls were at greater risk of being assaulted. ${ }^{11}$ This is a significant finding, because it indicates the gendered

\footnotetext{
${ }^{8}$ Ibid at 952.

${ }^{9}$ Ibid at 1026 .

${ }^{10}$ Ibid at 953 .

${ }^{11}$ Ibid at 1026.
} 
nature of the violence experienced by these youths. This data also includes a table of types of assailants reported by juvenile prostitutes. Looking specifically at the female respondents, $60.7 \%$ of assaults were committed by clients, followed by pimps $(24.1 \%)$, other prostitutes $(13.8 \%)$ and police officers $(11.0 \%) .^{12}$

The commentary that follows in the Report from these statistics is largely a description of the risk involved in working as a prostitute, as well as references to several informal and formal protective practices the respondents utilized when victimized. In its entirety the discussion of violence in the lives of juvenile sex workers spans three to four pages of the 345 page section on juvenile prostitution. The bulk of the discussion on juvenile prostitution deals with the nature and characteristics of the youth who were involved in prostitution, their family history, past abuse, their life on the streets, and the laws related to juvenile prostitution.

The Badgley Report in its conclusion issued 52 recommendations to help confront the sexual exploitation of youth. In terms of juvenile prostitution, this included the creation of new offences intended to "protect" youth and to criminalize procurers and customers of prostitutes under 18 years of age. While the Committee generally espoused social rather than legal initiatives, they reluctantly concluded that in order to bring youth into situations where they can receive guidance, it is necessary to have a specific criminal sanction prohibiting youth from engaging in prostitution. ${ }^{13}$ In other words, there was an endorsement of the criminalization of youth prostitutes, based on an assumption that the criminal law could be used as a tool to assist youths out of prostitution. The implications of this view will be taken up in the next chapter. While the Badgely Committee did

\footnotetext{
${ }^{12}$ Ibid at 953 .

${ }^{13}$ Ibid at 1046 .
} 
acknowledge that prostitutes were victims of violence to a greater degree than other members of society this recognition did not seem to inform the recommendations. None of the recommendations addressed the issue of violence against youth prostitutes, either directly or indirectly.

\section{Special Committee on Prostitution and Pornography in Canada - The Fraser}

\section{Report}

Even as the Badgely Committee was completing its work, the problems of pornography and prostitution were on the rise as pressing concerns for Canadians. ${ }^{14}$ To assess these issues, the Fraser Committee was established in 1983. The Fraser Committee issued its report in 1985, only a year after the release of the Badgley Report. I summarize the Fraser Report in greater depth, because it was, and is to date, one of the most comprehensive undertakings of research and discussion on prostitution in Canada. It is also one of the most innovative Reports in terms of its recommendations. At the time of the Committee's writing, they acknowledged that "historical and empirical information about prostitution in Canada is largely absent from the available research and literature." ${ }^{15}$ This was something the Badgley Committee had noted as well in its review of Canadian literature on juvenile prostitution. The Badgley Report described existing sources as of limited use. While foreign literature was more readily available and in abundance, it did not accurately reflect the situation in Canada. ${ }^{16}$ The lack of pre-existing literature inspired the Fraser Committee to gather a significant amount of information.

\footnotetext{
${ }^{14}$ James R. Robertson, "Prostitution," Current Issue Review 82-2E (Ottawa: Library of Parliament, 1999). Available at: http://dsp-psd.pwgsc.gc.ca/Collection-R/LoPBdP/CIR/822-e.htm

${ }^{15}$ Report of the Special Committee on Pornography and Prostitution: Pornography and Prostitution in Canada (Ottawa: Canadian Government Publishing Centre, 1986) at 365.

${ }^{16}$ The Badgley Report, supra note 5 at 1043.
} 
As background research for the Fraser Committee, the federal Government sponsored a study of newspaper reports on pornography and prostitution, a study of prostitution and venereal disease, three studies of pornography and prostitution laws in other countries, a review of the United Nations Conventions on Prostitution, a national survey of public attitudes on prostitution and pornography, and five regional studies that examined the business of prostitution and its control across Canada. State sponsored research was also conducted which produced several papers and publications on the issue of prostitution, and a number of academic works discussing the history of prostitution law in Canada. ${ }^{17}$

The Committee refers to the polarized public debate and related problems pertaining to and associated with prostitution and pornography stating "Few other social issues have so divided our public's opinion." 18 The Committee's goal and mandate were to try to better understand prostitution in general: "We believe that unless we understand the phenomenon we are seeking to control, our efforts towards that end will not be overly successful."19 With this goal in mind, the Committee sought information and input directly from a wide range of sources in addition to the commissioned research. This included various groups that contributed briefs and submissions, interviews with stakeholders, and consultation with the public.

For the purpose of my analysis I only focus on those sections of the Report that pertain to prostitution. In this context, it was the Committee's task to consider prostitution in Canada, with particular reference to loitering and street solicitation, the operation of bawdy houses, living off the avails of prostitution and the exploitation of

\footnotetext{
${ }^{17}$ Lowman, supra note 4 at 58.

18 The Fraser Report, supra note 15 at 5 .

${ }^{19}$ Ibid. at 366.
} 
prostitutes and the law relating to these matters. ${ }^{20}$ Additionally a strong focus, which has been pursued by every examination of prostitution since, was on the public nuisance and community harm aspect of prostitution. ${ }^{21}$ This "harm" referred to the effects of prostitution cited by citizens and neighborhood groups in areas frequented by prostitutes, such as excessive noise, loitering, used condoms, needles and other drug paraphernalia as well as car traffic. These issues were addressed by ascertaining the public's views on ways and means to deal with the problems associated with prostitution through submissions, interviews and meetings with groups and citizens.

Nowhere in the Committee's mandate was there reference to violence in the lives of prostitutes. The predecessor to this Report, the Badgley Report, noted a significant incidence of violence in the lives of juvenile prostitutes. This data should have prompted the Fraser Committee to take up the issue of violence and investigate further. Instead, with little discussion of violence against prostitutes, there is a strong focus on community "harm" and criminal law reform. ${ }^{22}$

\section{$\underline{\text { Stakeholders and the Public }}$}

Stakeholders involved in the consultations were feminist groups, neighborhood organizations, the public (i.e. mainly neighborhood, community groups and concerned

\footnotetext{
20 Ibid at 5 .

21 "Community" is a social construct, and has different meanings within political discourse. Anthony P. Cohen's work on community, belonging and identity argues that 'community' is a cultural phenomenon and that people construct community symbolically, making it a resource and repository and a referent of their identity (Cohen, 1982; 1985). In other words, community is not limited to the idea of buildings and neighborhoods; community is a set of shared values, expectations and references that exist and are common between people. It varies from group to group and is constantly changing. In the context of prostitution, prostitutes are seen as outsiders to the community. Even though prostitutes are themselves a community, they are viewed as "trespassers" who bring harm, and are seen as disrupting the harmony, morals and social cohesion of the "community."

22 The Fraser Report, supra note 15 at 5.
} 
citizens), current and former prostitutes, law enforcement as well as other representatives of the Government and the justice system who had legal or academic backgrounds in matters pertaining to prostitution. The hearings held by the Fraser Committee demonstrated that the Canadian public was divided on the issue of street prostitution. The Committee noted that there was a clear dichotomy. Police, civic officials and community associations saw prostitution as a nuisance and tended to favour tougher laws and increased criminalization with the goal of driving prostitutes off the street with very little discussion as to where they might go. ${ }^{23}$ Women's groups, social workers and some churches were primarily concerned with the welfare of the prostitutes themselves, whom they considered to be victims, rather than criminals. ${ }^{24}$

Prostitutes and prostitute organizations were involved in the hearings and submitted briefs to the Committee but it is difficult to gauge from the Report itself just how active and included they were and what influence, if any, they had on the overall discussion and recommendations. Prostitutes and their affiliated groups and organizations, along with gay rights organizations, most women's groups, and civil libertarians, mainly provided suggestions for legal reform. They recognized the detrimental effects that criminalization had on the safety and well being of prostitutes who worked on the streets, and the discriminatory nature of the enforcement of the soliciting law. Therefore, they proposed and supported decriminalization or partial decriminalization. The Canadian Organization for the Rights of Prostitutes in Toronto argued that decriminalization would allow prostitutes to work indoors, thereby creating a

\footnotetext{
${ }^{23}$ Ibid at 345 .

24 Ibid.
} 
safer work environment. It would also increase security for prostitutes by reducing the potential for exploitation by customers, police and pimps. ${ }^{25}$

The input of individual sex workers and or former sex workers was generally supportive of the decriminalization argument. But they also spoke of their treatment by society at large, something that is indicative of the violence they experience and the lack of basic human rights they are afforded. One sex worker stated,

For years I had very low self esteem. Society's attitudes makes one feel different about themselves. The reinforcement that you're a whore, that you're nothing, that you're a low life does have an impact on how you feel about yourself." 26

This sort of treatment by customers, the public and police was referred to by many sex workers, leading the Committee to conclude, "It is apparent they [prostitutes] suffer enormous indignities..."27 Examples such as this speak to the critical role that society plays in the social and legal response to prostitution; law reflects the attitudes of the society it represents.

The Committee focused a great deal on the "public's" views and perceptions of prostitution and the women involved. ${ }^{28}$ The National Population Study on Pornography and Prostitution included 2,018 Canadians 18 years and older. The survey was designed to learn about Canadians' attitudes towards, knowledge of, and perceptions of pornography and prostitution. ${ }^{29}$ From this survey, the Committee concluded that Canadians' views on prostitution have not been molded by their own experiences or

\footnotetext{
${ }^{25}$ Ibid at 358.

${ }^{26}$ Ibid at 394.

${ }^{27}$ Ibid.

${ }^{28}$ The "public" in this case refers to the individuals surveyed by the Committee in the National Population Survey, as well as concerned citizens and neighborhood organizations who submitted briefs and spoke at the consultations

${ }^{29}$ The Fraser Report, supra note 15 at 397.
} 
observations but by what they read and see in the mass media. ${ }^{30}$ The Committee goes on to say that media coverage of prostitution related issues has not been particularly comprehensive and it is not surprising, therefore, that the public is not particularly well informed or knowledgeable about the current situation of prostitution. ${ }^{31}$

Having consulted with the public, the Committee concluded "It is safe to say that prostitution is an identifiable activity in medium sized and large cities in Canada, and is certainly not unknown, but perhaps less visible, to the average citizen in smaller cities and towns around the country.",32 These consultations revealed the "public's" largest issue with street prostitution to be the perceived harm caused to communities. First hand accounts were obtained from tenant associations, neighborhood groups and so forth. One association noted, "The tenants suffer a serious decline in the quality of their living conditions and environment." 33 Others observed, "(there is) congestion on the sidewalk, high noise levels, increased vehicular traffic, with disregard of laws, harassment, and lack of safety in the evening.",34

\section{The Fraser Committee on the Soliciting Law}

A common agreement among all stakeholders was the dissatisfaction with the soliciting law, something the Committee discussed at length. The previous "Vag C" law had been repealed in 1972 and replaced with Section 195.1 (the soliciting law) which stated, "“"Every person who solicits any person in a public place for the purpose of

\footnotetext{
${ }^{30}$ Ibid at 396.

${ }^{31}$ Ibid.

${ }^{32}$ Ibid.

${ }^{33}$ Ibid at 346 .

${ }^{34}$ Ibid.
} 
prostitution is guilty of a summary conviction offence." ${ }^{35}$ At the time of the Committee's writing, the soliciting law had been in place for over ten years and was viewed by most as ineffective. According to John Lowman, the Committee was charged with the task of ascertaining what had gone wrong with the soliciting law, and why it had failed. ${ }^{36}$ Since its inception, the law had received a great deal of criticism, satisfying none of the many groups and critics on the various sides of the debate.

Two main problems were said to have emerged. One had to do with the definition of "solicit" established by the Supreme Court of Canada in $R v$. Hutt, a case which involved a prostitute who had been approached by an undercover police officer. ${ }^{37}$ The majority of the Supreme Court of Canada held that for the activities of a prostitute to be criminal, her conduct must conform to the dictionary definition of solicit; that is to say, it must be importuning, or "pressing and persistent" and constitute more than a mere indication that she was willing to prostitute herself. ${ }^{38}$ The decision made it a requirement for the act of soliciting to be obvious in order for there to be a crime, therefore a charge. Critics felt this decision did not allow police officers to deal effectively with prostitution and allowed prostitutes to escape arrest and find ways to continue their trade as long as their behaviour was not "pressing and persistent." The second problem with the soliciting law was similar to the problem with the "Vag C" law. Despite the switch to gender neutral language, the soliciting law was interpreted by the

\footnotetext{
${ }^{35}$ S 195.1 Criminal Code of Canada (repealed in 1985).

${ }^{36}$ John Lowman, supra note 1.

${ }^{37}$ R. v. Hutt (1978) 2 S.C.R. 476.

${ }^{38}$ Lowman, supra note 36.
} 
courts as applying only to the actions of female prostitutes. The law continued to be applied in a highly discriminatory manner. ${ }^{39}$

Most stakeholders who participated in the Fraser Committee hearings felt that section 195.1 was not addressing their concerns with regards to prostitution related activities. It had not decreased the incidents and presence of women working on the streets and enforcement was still discriminatory. The law did not distinguish between customer and prostitute and it was not clear if a customer could be charged with soliciting. With reference to the soliciting law the Committee concluded "It is now clear that the section is of minimal value in addressing the problems associated with prostitution." 40 The Committee also acknowledged the negative impacts the law had on women involved in street prostitution. They observed,

The current system of prostitution assigns to the prostitute a disproportionate part of the responsibility for the activities (associated with prostitution). While there are others who suffer, it is the prostitute who is most severely harmed. This is the case whether one looks at the more abstract question of prostitute's status in society and their standing in law, or at their daily experiences... ${ }^{41}$

\section{Criminalization, Harassment and Violence}

There is no specific section in the Report dedicated to discussion of violence on the street, instead it is mentioned in small statements in several parts of the report in the context of distinct discussions. For example, in the Committee's discussion of "customers" and the demographics and characteristics of men who buy sex and the services of prostitutes, a paragraph states, "Customers are the primary source of sexual violence against prostitutes and may be the cause of most of the violence prostitutes

\footnotetext{
${ }^{39}$ Robertson, supra note 14.

${ }^{40}$ The Fraser Report, supra note 15 at 425.

41 Ibid at 394.
} 
experience depending on the prevalence of pimps." 42 They go on to note that, "The majority of prostitutes have been sexually assaulted at least once by a customer, and have had money stolen from them or withheld despite the provision of services."43

Most of the information relating to violence was taken directly from the testimony of current and former prostitutes. Based on accounts provided by prostitutes, the Committee drew conclusions about the public in general as well as prostitutes' customers. According to the Report, “The public's attitude towards prostitutes is ambiguous. Some customers feel little compunction about assaulting or stealing from prostitutes. Others feel entitled to abuse prostitutes verbally, throw things at them and to indicate they have no right to be on the streets." ${ }^{44}$ Other stakeholders who testified at the consultations held by the Committee commented on violence in the lives of street prostitutes. One Niagara region police officer noted, “...the public should be aware of the dark side of prostitution such as violence towards prostitutes by pimps and clients."45 The Committee concluded that virtually all women prostitutes have been sexually assaulted, some of them as often as three to four times a year. ${ }^{46}$

\section{Criminalization is not the Answer}

The Fraser Committee made a number of recommendations on street prostitution, several of which are relevant to the issue of violence against prostitutes. One clear fact that emerged from their work was the ineffectiveness of the soliciting law and of the criminalization of women who work as street prostitutes. They conclude, "The law on

\footnotetext{
${ }^{42}$ Ibid at 388.

${ }^{43}$ Ibid at 388 .

${ }^{44}$ Ibid at 393.

${ }^{45}$ Ibid at 350.

${ }^{46}$ Ibid at 394.
} 
prostitution, as presently constituted, has not achieved what is presumably its theoretical objective, and that is reducing prostitution...moreover, it operates in a way which victimizes and dehumanizes the prostitute." ${ }^{47}$ This lead to several of the Committee's most significant and progressive recommendations which called for the decriminalization of prostitution related activities. However, they did not support full decriminalization, recommending only partial decriminalization. The Committee recommended the repeal of the soliciting law, and relaxing the bawdy house laws so that prostitutes 18 years and older could work out of their homes or in small scale non-residential establishments. ${ }^{48}$ This logic was grounded in the belief that "prostitution related activities should not take place in public places because of the offence involved and the proven dangers to prostitutes which the street life produces."49 Remaining offences relating to procuring, living off the avails, and some sections of the bawdy house laws were to be amended so that only provisions that dealt with exploitive conduct, or conduct which is violent or threatens force would remain in the Criminal Code. ${ }^{50}$ The Committee felt that existing legislation with certain amendments could target any potential nuisance or loitering problems that may still arise in relation to prostitution so as to address the concerns of neighborhoods and communities.

Paradoxically, the Government of the day under the leadership of the Progressive Conservative party chose to ignore the Fraser Committee's recommendations and instead, pass the law we now have in place, section 213 of the Criminal Code, known as the

\footnotetext{
${ }^{47}$ Ibid at 535 .

${ }^{48}$ Ibid at 537.

${ }^{49}$ Ibid at 535 .

${ }^{50}$ Ibid at 538-539.
} 
communicating law. ${ }^{51}$ The key difference in this law was that it removed the ambiguity of the term "solicitation" by explicitly prohibiting public offers to purchase sexual services as well as offers to provide them. ${ }^{52}$ It also solidified the concept that "every person" means men and women selling sexual services and includes clients. The amendment also included "motor vehicle" in the definition of a public place. ${ }^{53}$

\section{Evaluating and Challenging the Communicating Law}

Following the Fraser Report and the enactment of the communicating law, the Department of Justice funded regional studies in 1987 and 1988 in Vancouver, Calgary, Toronto, Montreal and Halifax specifically to evaluate the communicating law. ${ }^{54}$ The result of the five studies was published in a report in 1989 titled "Street Prostitution: Assessing the Impact of the Law." 55 These studies concluded that the new communicating law had very little impact on the levels of street prostitution in most Canadian cities. ${ }^{56}$ Many citizens' groups and police forces had welcomed the communicating law, as they felt that it gave police a broader level of enforcement and moved prostitutes out of particular neighborhoods. Other groups, including civil libertarians and feminist groups, argued that it merely moved the problem of street prostitution to new locations (mainly to unsafe, isolated areas where prostitutes felt they

\footnotetext{
${ }^{51}$ See Criminal Code Appendix for full citation of the communicating law.

${ }^{52}$ John Lowman, "Prostitution Law Reform in Canada" Toward Comparative Law in the $21^{\text {st }}$ Century. Institute of Comparative Law in Japan ed. (Tokyo: Chuo University Press, 1998). Available at: http://users. uniserve.com/ lowman/

${ }^{53}$ Report of the Subcommittee on Solicitation Laws of the Standing Committee on Justice and Human Rights The Challenge of Change: A Study of Canada's Criminal Prostitution Laws (December, 2006) at 42. Available at: http://cmte.parl.gc.ca/Content/HOC/committee/391/just/reports/rp2599932/justrp06/sslirp06e.pdf

${ }^{54}$ See Brannigan, et. al., 1989; Gemme, et. al., 1989; Graves, 1989; Lowman, 1989; Moyer and Carrington, 1989

${ }^{55}$ John, Lowman, Street Prostitution: Assessing the Impact of the Law, Vancouver (Ottawa: Department of Justice, 1989).

${ }^{56}$ Lowman, supra note 1.
} 
would not be detected by police) and that it gave too much discretion to the police and prosecutorial authorities. These groups were concerned that the new law further endangered prostitutes. $^{57}$

The Standing Committee on Justice and the Solicitor General was responsible for reporting to Parliament on the results of the three year review of the communicating law based on the five regional studies and subsidiary research and studies. In the process of conducting its review, the Standing Committee consulted city mayors, police officers and community groups about the impact of street prostitution on the neighborhoods in which it occurs. Also, the Committee interviewed researchers about the results of the regional studies, and conducted a survey of services and programs available to prostitutes across Canada. $^{58}$

The Standing Committee tabled their report in 1990 issuing three recommendations. The first recommendation called for the development and funding of programs to assist male and female prostitutes in exiting prostitution. The remaining two recommendations entailed strengthening the laws and stricter enforcement. For example, they recommended amending the Identification of Criminals Act ${ }^{59}$ to allow for fingerprinting and photographing those charged with the offence (this would overwhelmingly be the women involved in prostitution). The third recommendation suggested that the communicating law be amended to provide sentencing judges with the discretion to prohibit persons convicted of street solicitation involving a motor vehicle from driving a motor vehicle for a period not to exceed three months, along with any

\footnotetext{
${ }^{57}$ Robertson, supra note 14.

58 Lowman, supra note 52.

${ }^{59}$ The Identification of Criminals Act. (R.S., 1985, c. I-1).
} 
other penalty imposed. ${ }^{60}$ The Government responded in 1991 rejecting all three recommendations, but saying that the penalty issues raised in the last two recommendations would be taken into account in proposed legislation dealing with sentence reform. ${ }^{61}$ However, to date, these recommendations have not been implemented.

Prior to the release of the Standing Committee's Report, the communicating law was challenged in a case that went to the Supreme Court of Canada in $1990 .^{62}$ Dorman Skinner was arrested while trying to proposition an undercover police officer. He was charged with "communicating in a public place for the purpose of obtaining the sexual services of a prostitute" contrary to section 213 of the Criminal Code. He was convicted at trial and on appeal argued that the provision violated his right to freedom of expression under section 2(b) of The Charter of Rights and Freedoms. ${ }^{63}$ The Supreme Court majority, with two justices dissenting, ruled that the provisions infringed the freedom of expression guaranteed by section 2(b) of the Charter of Rights and Freedoms but are justified under section 1 of the Charter as reasonable limits on freedom of expression that are demonstrably justified in a free and democratic society. ${ }^{64}$ The communicating law was upheld.

\section{The Federal/Provincial/Territorial Working Group on Prostitution}

Further studies and academic literature on prostitution over the next ten years provided researchers, Government and the public with additional knowledge and

\footnotetext{
${ }^{60}$ Lowman, supra note 55.

${ }^{61}$ Robertson, supra note 14.

${ }^{62}$ R. v. Skinner, [1990] 1 S.C.R. 1235.

${ }^{63}$ Canadian Charter of Rights and Freedoms, s. 2(b), Part I of the Constitution Act, 1982, being Schedule B to the Canada Act 1982 (U.K.), 1982, c.11.

${ }^{64}$ Ibid.
} 
demographics. Of importance to my inquiry and research are the discussions and information on violence against prostitutes which also appear in this time period. Statistics Canada issued several reports in the 1990's providing some alarming figures, which I detailed in the preceding chapter. ${ }^{65}$ The statistics reports also cite a study done in 1994 and 1995 on behalf of the Department of Justice in Halifax, Montreal, Toronto, Calgary, Winnipeg and Vancouver which confirmed that physical and sexual assaults on street prostitutes are carried out by clients, pimps and boyfriends. ${ }^{66}$ A Juristat report in 1997 states, "There were six known prostitutes killed in the course of their work in 1997. It should be noted that the number of prostitutes reported killed most likely under represents the actual figure." ${ }^{67}$ As discussed at length in the previous chapter, research by academics and experts in both Canada and outside of Canada, also began appearing in larger quantities. This literature provided statistics and data on incidents of violence as well, and actually informed subsequent committees. Prostitutes' rights organizations and social agencies supporting prostitutes began to collect information and cite incidents of harassment and violence in an effort to promote the safety of prostitutes and to create a higher level of public awareness of the issue.

Armed with a larger volume of research, literature and studies on prostitution (and violence against prostitutes), a Working Group on Prostitution was established by the Federal, Provincial and Territorial Deputy Ministers responsible for Justice in 1992. They were given a mandate to review legislation, policy and practices concerning prostitution related activities and to bring forward recommendations to address problems

\footnotetext{
${ }^{65}$ Supra , at 50. Between 1991 and 199563 known prostitutes were murdered, almost all were female. Cited in D. Duchesne, "Street Prostitution in Canada" Juristat, 17:2 (Ottawa: Statistics Canada, 1997) at 1 ${ }^{66}$ Ibid.

${ }^{67}$ Orest Fedorowycz, "Homicide in Canada" Juristat, 18:12 (Ottawa: Statistics Canada, 1997) at 10.
} 
posed by prostitution. ${ }^{68}$ The final report of this group was released in 1998. The primary concerns addressed in the Report were youth involvement in prostitution and the harm to communities that prostitution related activities created. However, they also briefly addressed violence against prostitutes. At the outset of their report they state "Two issues have gained a high public profile: youth involved in prostitution and the harm associated with prostitution." They go on to add, "The problem of violence against prostitutes is also raised frequently as it is related to both these issues." ${ }^{, 69}$ A large part of the report addresses these two high profile concerns, with some secondary discussion of the violence.

Similar to the Fraser Report, the Working Group's Report is an extremely thorough account addressing almost every aspect of prostitution. The Report provides historical context, definitions, analysis of previous reports, legal and policy changes, alternative approaches, and discusses at length recommendations for Criminal law reform and a review of legal models adopted by other countries in dealing with prostitution. I again, for my purposes, focus on their discussion of street prostitution which is part three of their four part report, and finally on their discussion of violence against prostitutes.

\section{$\underline{\text { Harm to Prostitutes and Harm to Communities }}$}

This is the first report to address, rather than merely mention, the seriousness of violence against prostitutes and to discuss it in greater length. One section spanning approximately two pages is dedicated exclusively to the issue of violence against street

\footnotetext{
${ }^{68}$ Federal/Provincial/Territorial Working Group on Prostitution, Report and Recommendations in Respect of Legislation, Policy, and Practices Concerning Prostitution Related Activities (December 1998). Available at: http://www.justice.gc.ca/en/news/nr/1998/toc.html ${ }^{69}$ Ibid.
} 
prostitutes. Several additional points on violence are made in other areas of the Report when discussing street prostitution in general, and in relation to the effects of the criminal law. The research compiled by John Lowman and other experts and researchers on violence against prostitutes in Canada is cited and discussed. The Report acknowledges the serious nature of violence and possible contributing factors. Importantly they state, "Research indicates a relationship between victimization of prostitutes, including assaults and homicides, and the venue of the sex trade. Nearly all assaults and murders of prostitutes occur while the prostitute is working on the street."70 At the same time they also establish that many neighborhoods and businesses have identified street prostitution as a major nuisance. These two insights, discussed together, lead to the Committee's conclusion that the clear direction emerging from their consultations and research is that strategies to deal with prostitution should have two major objectives: one, the reduction of harm to communities, and two, the prevention of violence towards prostitutes. ${ }^{71}$

The Committee perceives a conflict between these two strategies, particularly where community harms are addressed. Reducing the community harm associated with street prostitution requires a decrease in the visibility of prostitution related activities, and this generally amounts to displacement of prostitutes to less visible more remote areas, which could increase the risk of violence. ${ }^{72}$ However, there would be less of a conflict between reducing harm to communities and harm to prostitutes, if the harm to prostitutes was addressed first and foremost. The implications of this will be discussed further in the ensuing chapter.

\footnotetext{
${ }^{70}$ Ibid.

${ }^{71}$ Ibid.

${ }^{72}$ Ibid.
} 
Just as the Fraser Report critiqued Canada's prostitution legislation, and the previous soliciting law, the Working Group's report discusses at length the many problems with Canada's prostitution laws and in particular, the communicating law. The Report states, "Members of the working group continue to be concerned about the discriminatory impact the enforcement of Section 213 of the Criminal Code has on prostitutes, most of whom are women."73 They acknowledge that before the passage of the communicating law many social agencies, women's groups and women working in the sex trade had voiced their opposition to it, because they felt it would have the effect of increasing the vulnerability of women involved in street prostitution to further violence. They foresaw that the new law would make prostitutes more liable to arrest and prosecution, as well as put them at greater risk of victimization by pimps and customers. $^{74}$

The Report then outlines the statistics from Statistics Canada mentioned above as well as the research completed by John Lowman and the studies commissioned by the Department of Justice. In presenting findings from these regional studies, the Report cites the example of Montreal, where there was evidence that enforcement of section 213 had resulted in prostitutes working in more remote areas, and being less careful in choosing from a diminished number of customers. ${ }^{75}$ They discuss the situation in Halifax where Crown policies resulted in the successful arrests of large numbers of pimps. However, in the absence of protection programs for prostitutes, these policies ultimately contributed to violence against street prostitutes who had to testify against their pimps. ${ }^{76}$

\footnotetext{
${ }^{73}$ Ibid.

74 Ibid.

75 Ibid.

${ }^{76}$ Ibid.
} 
All regional studies reported a considerable number of prostitutes being threatened, beaten, stabbed, raped, strangled, kidnapped and robbed. The Working Group concluded that Criminal Code amendments are not the most appropriate mechanisms for responding to street prostitution and that any decisions relating to street prostitution must take into account the potential for increased violence against prostitutes. ${ }^{77}$

\section{The Working Group's Recommendations}

One of the Report's recommendations involved police strategies including the implementation of High Risk Homicide Registries developed in Alberta by the RCMP. These are registries for persons believed to be at risk of becoming victims of homicide. It is voluntary and collects information such as height, weight, identifiable marks and so forth. Information about the individual's lifestyle is also collected. The registry was established as a result of the large numbers of unidentifiable bodies of prostitutes disposed in remote areas in rural Alberta. ${ }^{78}$ From a law enforcement perspective, the purpose of these registries is to facilitate identification of the victim, as well as aid in a speedy investigation and arrest of a suspect. The Working Group recommended that law enforcement agencies in other provinces and territories consider establishing such registries in order to assist police in quickly and accurately identifying bodies in cases of homicide and, to potentially assist, in particular youths, to re-examine their involvement in the sex trade. ${ }^{79}$ The problematic nature of this recommendation will be discussed in the following chapter.

\footnotetext{
77 Ibid.

78 Ibid.

${ }^{79}$ Ibid.
} 
The Working Group's other recommendations pertaining to street prostitution reflect a divided public and a division among the members of the Working Group itself. They could not reach a consensus on the appropriate legal or social remedies to address the issues, a theme that is apparent in most responses and proposals relating to prostitution. As a result many issues raised in the Report, such as the safety and well being of prostitutes, were not addressed in the recommendations. However, among their general recommendations they agreed that further criminalization was not the solution due to the negative impact it would have on prostitutes. At most, this report merely informed Government and society about the current situation of prostitution in Canada, and provided up to date information, literature and statistics highlighting the very real and critical issue of violence against street prostitutes.

\section{What was achieved?}

After three major committees and reports on prostitution very little was achieved. Not only was there no progress or change in terms of social or legal reform, there was either inadequate or no dialogue and analysis on the safety and working conditions of female prostitutes. We have in no way advanced forward on the issues as a result of these reports, mainly because of the Government's inaction and failure to take up the issues of abuse and violence in the lives of prostitutes, and their refusal to acknowledge or consider those contributing factors, such as ineffective and discriminatory legislation, and enforcement, as well as persisting stereotypes that continue to render sex workers as second class citizens. In terms of the issue of violence against street prostitutes in Canada, there are many questions, concerns, critiques and insights that emerge in the reading and analysis of the committees, their reports, their recommendations, and in turn 
the Government's response. The following chapter will take up these themes and related critiques. 


\section{Chapter Five}

\section{Deconstructing the Prostitution Problem and Reconstructing Violence against \\ Prostitutes}

There are common themes and critiques that arise from the reports discussed in the previous chapter, as well as individual insights I wish to make on each one. My overall observation is that a serious and thorough discussion about violence in the lives of street prostitutes is not contained in any of the reports. Violence against prostitutes is but one small facet. Accounts, statistics, research and discussions on violence are referred to but not examined in depth, and they do not result in any comprehensive recommendations that take the problem of violence in the lives of prostitutes seriously. Several recommendations issued by the Fraser Committee, had they been implemented, may have been a step in the right direction in creating safety measures and harm reduction strategies, however these recommendations were largely ignored. The reports do present a clearer picture and a better understanding of prostitution in Canada in general, and an examination of its social, legal and political implications. However, the ongoing characterization of prostitution as a "social problem" and "criminal law" problem has not allowed the committees, the Government or the public to move beyond these aspects of prostitution and move forward to more innovative solutions in dealing with prostitution generally, and violence against prostitutes specifically. The treatment of prostitution as such, has produced lengthy reproductions of the traditional debates surrounding prostitution, emphasized the controversial nature of prostitution, and has echoed the same talk about legal reform. 
The dominant focus in all reports on the status of prostitution, juvenile prostitution and community harms, has overshadowed discussion of the negative impact the structure and enforcement of Canadian prostitution law has on the levels of violence against female prostitutes, as well as the social marginalization and discrimination that render prostitutes second class citizens. The severity of violence that has been occurring and continues to occur for women who work in the street level sex trade industry in Canada appears secondary in the reports and has been almost completely ignored by the Government in responding to the reports. My criticism and commentary are not directed exclusively at the committees' limited and incomplete examination of violence against street prostitutes, they are more forcefully directed at the Government's response or lack thereof to the reports' findings. In the period beginning with Badgley and ending with the Working Group's Report, there was little or no direct action taken by the Government to address these concerns and the well being and safety of women working as street prostitutes. The Canadian Government and justice system must take on this issue in order for change to be realized. Very little social policy or legal change can occur without some level of government endorsement. Ultimately, the lack of leadership on the part of Government has blocked the recommendations that have been brought to address the violence by sex workers themselves, researchers, and others. Violence against female street prostitutes continues largely unabated.

\section{Research and Evidence}

The Badgley Committee, the Fraser Committee and the Working Group were all armed with evidence, information, statistics and first hand accounts of severe mistreatment, abuse and violence in the lives of female street prostitutes in Canada. The 
findings on physical abuse in the lives of youth prostitutes in the Badgley Report presented the Committee, and in turn the Government, with evidence of a serious problem of violence against sex workers. Yet no special consideration was given to these figures. An important opportunity was missed to explore the incidence of violence and the impact of violence in the lives of young prostitutes in Canada. ${ }^{1}$ It is equally alarming that these figures did not prompt the Government to look further into the issue, given the high number of youth prostitutes who reported being victims of violence.

This leads to the most obvious criticism of the Fraser Report which followed shortly after Badgley. Having been presented with significant evidence of violence in the lives of youth prostitutes, and presumably prostitutes in general, why did the Fraser Committee not take the opportunity to draw upon the findings of violence in the Badgley Report, and make this part of their mandate? John McLaren, a member of the Fraser Committee, rightly points out that committees receive their mandates from government, and this imposes an explicit understanding of what is "important" to look at. ${ }^{2}$ It is clear the Government completely overlooked the findings of abuse and violence against juvenile prostitutes presented by the Badgley Report, in directing the Fraser Committee in its work and focus. Nonetheless, the Fraser Committee was not entirely constrained in their mandate. They could have exercised some degree of autonomy and authority and expanded their mandate slightly or at least shifted the focus of their Report to include violence against prostitutes as an issue of significance. They conducted extensive

\footnotetext{
${ }^{1}$ Deborah Brock, Making Work, Making Trouble: Prostitution as a Social Problem (Toronto: University of Toronto Press, 1998) at 111.

${ }^{2}$ John McLaren. "The Fraser Committee: The Politics of a Special Committee" in Regulating Sex: An Anthology of Commentaries on the Findings of The Badgley and Fraser Reports. J. Lowman, MA Jackson, TS Palys \& S. Gavigan Eds. (Burnaby B.C: School of Criminology, Simon Fraser University, 1986) at 40.
} 
research and interviews which presented them with further observations and first hand accounts provided by those who work in prostitution and/or those who work closely with prostitutes of the dangers women working on the streets faced daily. In light of this information on the severe abuse experienced by a marginalized population of Canadian women, the Fraser Committee should have initiated a serious and lengthy investigation and discussion of violence against prostitutes.

The same observation applies to the Working Group's Report. Equipped with the largest body of work and evidence on violence and abuse against prostitutes, they were given an opportunity to make violence against prostitutes a central component of their Report. Instead, it is secondary. The Report's labeling of violence against prostitutes as an "emerging" concern is especially problematic, and inaccurate, since both Badgley and Fraser presented their findings over ten years prior, and literature, studies and research cited by the Working Group clearly indicate sex workers living and working in a culture of violence in Canadian cities for decades. The Working Group reiterates the statistics, data, and research presented by the Badgley Report and the Fraser Report, as well as additional studies and literature that emerged in large numbers in the time between the completion of the Fraser Committee's report and the Working Group's Report. The "emerging" ascription may have provided an excuse not to delve deeper into the issue, in an effort to keep the focus on what society and the Government have found to be the more "pressing" concerns of Canadians in relation to prostitution - youth involvement and community harms. Given all the information and the conclusions the reports present, the issue of violence against female street prostitutes should have been brought to the fore as the most urgent and pressing issue to be addressed. 


\section{Stakeholders}

The Working Group was made up of officials from the provincial, territorial and federal jurisdictions, whereas both the Badgley and Fraser Committee were made up of academics, doctors, judges, psychiatrists, social workers and other professionals with backgrounds in policing. However, neither committee included a representative of any sex trade. ${ }^{3}$ Women involved in the sex trade would have added greater legitimacy and expertise to the committees. They would have provided a sex worker perspective on all the issues, and may have guided the committees to a closer examination of the issues that were not given enough attention, such as violence and abuse.

In terms of consultations, the Fraser Committee and Working Group obtained information and opinions from a variety of stakeholders. ${ }^{4}$ The Fraser Report stated that their sources came primarily from police and municipal officials, community and business associations. A smaller number of women's groups, social work agencies and prostitution associations also provided input. Participants in the Working Group's consultations included a very broad range of groups and individuals, such as representatives of citizens groups, judicial officials, current and former prostitutes, municipal and provincial officials, educators, clergy, aboriginal groups, women's advocates and health and social work agencies.

It is not possible to accurately critique the reports about their inclusion or exclusion of sex workers, as it is difficult to know to what extent sex workers themselves were included, apart from the fact that the reports state sex workers were consulted.

\footnotetext{
${ }^{3}$ John Lowman "Canada" in Prostitution: An International Handbook on Trends, Problems and Policies. Nanette J. Davis ed. (Westport: Greenwood Press, 1993) at 57.

${ }^{4}$ By stakeholders I am referring to the individuals and organizations consuited as well as those who made and submitted briefs and testimonies to all committees.
} 
However, in reading the reports, aside from brief comments and testimony, the input of sex workers does not seem to be present in many important and relevant components of the reports, such as discussions on law reform, and violence and abuse. Greater efforts could have been made to encourage testimony from former and current sex workers. The Fraser Committee for example, held private hearings for those who wished to maintain their anonymity, because the public nature of the hearings often discouraged possible presenters from coming forward. Committee member McLaren acknowledges the disadvantage of these public hearings, noting:

We [the Committee] could have conducted more private hearings. The result of the rather perfunctory nature of these encounters was that, as a committee, we had all too little input from important players in the world of commercialized sex, such as prostitutes. ${ }^{5}$

Those who live and work as prostitutes can speak best to their experiences. Their voices need to be heard in order to provide legitimacy to the findings of these committees and to put practical solutions on the table for consideration.

\section{Focus on Youth Prostitution}

Youth prostitution is an issue that dominates the discussion and is well documented in all reports. The primary mandate of the Badgely Committee's work was the investigation of child abuse and sexual assault in the lives of Canadian youth. The issue remains dominant in the Fraser Committee's Report, and almost ten years later in 1998, the concern over the involvement of youth in prostitution continues with the F/P/T Working Group Report. In fact, part two of their four part Report is dedicated solely to the issue of youth prostitution and takes up the majority of the Report. Violence affects

\footnotetext{
${ }^{5}$ McLaren, supra note 2 at 43.
} 
all individuals in the sex trade, irrespective of their age yet the focus remains on juvenile prostitutes. Seen as helpless victims, youth prostitutes (and now trafficked women and children) dominate the political and social agenda, as non controversial, straightforward concerns to address and take up. With the spotlight on these particular concerns, backed by public alarm, it then becomes difficult to focus on the overall issue of violence against sex workers in general, as it is then seen and treated as less important.

This continued emphasis on youth prostitution is an example of what John Lowman calls the "child saving rhetoric," reflecting a movement that is washing across many parts of the world to combat traffic in women and children, and particularly the sexual exploitation of children. ${ }^{6}$ Youth prostitution and trafficking in women and children appeal to society as causes to rally against because the victims are vulnerable and most often unwilling. Women who are trafficked into the sex trade in Canada and or those minors who work in the sex trade are seen as rarely "choosing" prostitution whereas female adult street prostitutes are seen as making that choice and therefore responsible for whatever may befall them as a result, including the violence to which they are subjected. This imposes a victim dichotomy. Young prostitutes and trafficked women evoke sympathy and compassion; adults provoke scorn and derision. ${ }^{7}$

The public may have a hard time sympathizing with women whom they see as deserving the treatment they receive and have an easier time sympathizing with "worthy" victims. This echoes the historical treatment of battered women by society and by the

\footnotetext{
${ }^{6}$ John Lowman, "Prostitution Law Reform in Canada" Toward Comparative Law in the $21^{\text {st }}$ Century. Institute of Comparative Law in Japan ed. (Tokyo: Chuo University Press, 1998). Available at: http://users.uniserve.com/ lowman/

${ }^{7}$ John Lowman, "You Can Do it, But Don't Do it Here: Some Comments on Proposals for the Reform of Canadian Prostitution Law" in Regulating Sex: An Anthology of Commentaries on the Findings of the Badgley and Fraser Reports. J. Lowman, MA Jackson, TS Palys \& S. Gavigan eds. (Burnaby B.C: School of Criminology, Simon Fraser University, 1986) at 199.
} 
justice system. Battered women were generally not seen as victims but as women who had chosen to stay in abusive relationships or who under their marriage contract accepted the treatment inflicted upon them by their spouses. The criminal justice system was thus perceived to have no role in these "consensual" violent relationships. Similarly, the criminal justice system is seen to have no role with respect to the violence done to prostitutes who have "chosen" a life of violence.

\section{Harm and Violence}

\section{$\underline{\text { Community Harms }}$}

The "nuisance" aspect and harm to communities emerge and continue as the dominant concerns mainly in the Fraser Report and the F/P/T Working Group Report. Communities and businesses do experience negative effects from street prostitution operating in their neighborhoods, such as excessive noise, loitering, and in some instances condoms and drug paraphernalia being left behind. However the focus on these issues seems disproportionate. Critics argue that the community uproar over prostitution is not always or only a result of the perceived direct nuisance of activities associated with prostitution, but based on moralism and society's discomfort with the idea of nonmonogamous sexual relations such as prostitution. Brannigan and Fleischman conclude that prostitution causes "nuisance" not through soliciting or car traffic from clients, but through its proximity to communities which reject any public acknowledgement that sex is recreation, that sex is entertainment and that it can be had commercially, anonymously 
and promiscuously. ${ }^{8}$ Shaver goes on to add that "If prostitution were seen to cause a nuisance simply through immodest soliciting, the drug trade and noisesome traffic, these activities would be singled out for proscription under the law." engage in prostitution who are targeted by and under the law, rather than the associated activities that residents complain about. This would seem to indicate that in fact it is the immorality of prostitution, and a community's unease with the idea of women exchanging sex for money in their neighborhoods, that is really at issue. Again, history repeats itself with prostitutes being blamed for both the degradation of communities, and the "moral decline" of a society.

While the concern of communities and businesses speak to the fact that they are negatively impacted by street prostitution and its possible effects, nuisance concerns should not take precedence over concerns of violence against sex workers. There should be no question of nuisance versus violence in terms of priority for action. The drug trade and criminal activity sometimes associated with prostitution are not always a direct result of prostitution. These are concerns that should, and can be remedied separately from the issue of prostitution itself. Addressing the safety of prostitutes may in effect go a long way towards eliminating community harms. The reports overlook that one of the primary reasons that these harms may occur is the fact that prostitutes are forced to work on the streets as a result of the enforcement of the prostitution laws. One of the biggest safety measures that could be implemented would be to allow prostitutes to work indoors or in designated areas. This safety measure may as a side effect, address many of the concerns

\footnotetext{
${ }^{8}$ A. Brannigan and J. Fleischman, "Juvenile Prostitution and Mental Health: Policing Delinquency or Treating Pathology?" (1989) 4(77) Canadian Journal of Law and Society at 77.

${ }^{9}$ Frances. M Shaver, "The Regulation of Prostitution: Avoiding the Morality Trap" (1994) 9(1) Canadian Journal of Law and Society at 135.
} 
raised by neighborhood groups. It would remove the obvious presence of the sex trade, it would decrease the traffic of clients' cars and minimize visible soliciting by both prostitutes and clients.

\section{Misuse of "Harm"}

Harm to prostitutes is generally discussed by the committees and Government within the context of prostitution being inherently dangerous. ${ }^{10}$ Violence and prostitution are predominantly described as inseparable. There is an assumption that prostitution is by nature violent; violence is to be expected. For example, the Badgley Committee in noting the high levels of violence on the streets states,

The youths who survive by prostituting themselves in this environment are subject to considerable risks of contracting diseases and of being physically injured. These harms constitute serious occupational hazards that are inherent in prostitution. ${ }^{11}$

This statement contains two important points. First, the Committee refers to prostitution as an occupation. Doing so gives it legitimacy and implies that prostitutes are entitled to the basic rights of other workers, including protection from known occupational hazards, including violence. Labeling and acknowledging prostitution as an occupation opens up a whole new set of meanings in the way we understand prostitution, treat prostitutes and respond to their victimization. It may be that the Committee found it useful to refer to the harms as "occupational hazards" but in order for this understanding of prostitution to be meaningful, it has to be incorporated into the analysis of prostitution, including the violence. This reference might have been a small step toward the recognition of

\footnotetext{
${ }^{10}$ See previous discussion in chapter one of this thesis re: "harm" and "inherent violence" at 17-18.

${ }^{11}$ Sexual Offences against Children: Report of the Special Committee on Special Offences against Children and Youth (Ottawa: Supply and Services Canada, 1985) at 1026.
} 
prostitution as a legitimate form of work but the assertion is contradicted in the rest of the Report's treatment of prostitution, and is not adopted or taken up in later reports.

The second important point is the Badgley Committee's description of street prostitution as inherently violent. This conflation of prostitution and violence is extremely problematic and something we need to get away from in order to understand and challenge the real violence prostitutes experience. There is nothing inherently violent about the sex work these women (and in this case girls, men and boys) perform. As Lowman explains,

Unless one defines the act of payment for sexual services as a form of "violence," there is nothing about the act of prostitution that is intrinsically dangerous (while unsafe sex with multiple partners carries an obvious epidemiological risk, this is not usually what we mean by "violence"). ${ }^{12}$

Stating that prostitution is inherently violent in effect minimizes the violence because it assumes that violence comes with the job and that nothing can or really even should be done about it. Prostitutes are assumed or expected to accept and tolerate violence as part of their work. Their choice to work in the sex trade is understood as consent to the violence that ensues. This ideology echoes, again, other forms of violence against women. ${ }^{13}$ What is at play in many of these beliefs is the underlying assumption that in consenting to sex or marriage, a woman is consenting to at least some degree of violence. This assumption has made it very difficult historically for women to have the violence they experience from male partners or in conjunction with sex recognized and responded to. While we have made some headway in disassociating violence and sex and violence and marriage, these issues still very much inform the attitudes and responses to

\footnotetext{
${ }^{12}$ John Lowman and Laura Fraser, Violence against Persons Who Prostitute: The Experience in British Columbia. Technical Report No. TR1996-14e. (Ottawa: Department of Justice Canada, 1996). Available at: http://users.uniserve.com/ lowman/

${ }^{13}$ See discussion in chapter three of this thesis.
} 
violence against prostitutes. The perception of prostitution as inherently violent impedes our ability to challenge this violence.

In the Working Group's discussion of reform and recommendations, they note strategies to deal with violence against sex workers, in terms of the police response to abuse and violence. Specifically, this has been the development of high risk homicide registries. The suggestion of registries speaks to my point about equating violence and prostitution. "High risk" implies prostitution is violent. While the registry may prove beneficial for the relationship between police and prostitutes in terms of establishing trust and better relationships between prostitutes and law enforcement, registries do not address prevention. They are a means of identifying a woman once she is missing or deceased as pointedly described by the Working Group:

Crossroads, an outreach program in Edmonton, working in unison with the RCMP, collects the information from the registrants. It collects this information on the street and informs the prostitutes about why the information is being gathered, who will have access to it, and that the information will only be used to identify their bodies in cases of homicide. ${ }^{14}$

Registries might also be viewed as a scare tactic. The Working Group states,

The registry has assisted some prostitutes especially youth, to reexamine their involvement in the sex trade. Registering and volunteering particular kinds of information forces some of the individuals involved in the sex trade to come to terms with the risks involved with prostitution. ${ }^{15}$

This language again assumes that prostitution is inherently dangerous. It reflects outdated moral reformist strategies from the Victorian era that sought to have prostitute women and girls see the error of their ways. There is an assumption that if prostitutes

\footnotetext{
${ }^{14}$ Federal/Provincial/Territorial Working Group on Prostitution, Report and Recommendations in Respect of Legislation, Policy, and Practices Concerning Prostitution Related Activities (December 1998). Available at: http://www.justice.gc.ca/en/news/nr/1998/toc.html ${ }^{15}$ Ibid.
} 
realize that they can be physically harmed or killed, then they will not work selling sexual services. This completely overlooks the many reasons why girls and women have to work as prostitutes or choose to work as prostitutes. It assumes that if women and girls knew better they would not work in the sex trade because of its danger. Perhaps we should be suggesting that women and girls avoid marriage in order to avoid the abuse that sometimes accompanies marriage. Rather than focusing on trying to convince women that they can die from working in the sex trade, we should be making the conditions safer for those who have to, and those who choose to. The idea that women can and should be scared away from prostitution reinforces the perception that those who stay in prostitution accept the violence that goes with it. A more useful system, or rather a system that would work well in combination with registries, would be bad date lines or lists, something set up by many social agencies and prostitutes' rights groups and organizations. This allows sex workers to report bad clients, and to notify one another of violent customers or potentially violent customers.

The context in which harm and violence are discussed and taken up by the committees and in their reports are reflective of assumptions which see prostitution as inherently violent and a dangerous "lifestyle." Intended or not, framing the issue as such implies that sex workers are responsible for and have some control over their victimization when they are assaulted as long as they "choose" to remain in this environment. It overlooks the complexity of prostitution and the reasons why women work as prostitutes. Additionally, the disproportionate amount of importance placed on "harms" in communities where prostitution occurs, signifies that these problems are a direct result of prostitution, therefore the fault of prostitutes. This misfocus impedes our 
ability to primarily address the harms prostitutes experience, such as harassment, rape and murder, from clients, pimps and the public.

\section{Recommendations}

\section{More Criminalization?}

The Criminalization of prostitutes, something that the overwhelming majority of experts and scholars agree does not work, was implied or specifically recommended by several of the committees. ${ }^{16}$ The Badgley Committee, while noting its hesitancy in doing so, felt criminalization was required. In issuing this recommendation they commit the common fallacy of placing the blame on the victim, stating, "There are no effective means of stopping the demonstrated harms that these children and youths bring upon themselves..."17 They go on to explain that,

There is no desire on the part of the Committee to affix a criminal label to any juvenile prostitute, however in order to bring these children and youths into situations where they can receive guidance and assistance, it is first necessary to hold them, and the only effective means of doing that, is to have a specific criminal sanction prohibiting children and youths engaging in prostitution. ${ }^{18}$

There are three problems with this statement. First, as Lowman points out, is the suggestion that young prostitutes "bring upon themselves" the "demonstrated harms" of

street life. ${ }^{19}$ This logic justifies violence against prostitutes and perpetuates the myth that in choosing this "lifestyle" prostitutes choose to be victims of abuse. Second, not only does this recommendation imply that prostitutes are to blame for their own victimization, it also implies that the only way to be protected is to be shown the error of

\footnotetext{
${ }^{16}$ Criminalization per se may not have been the recommendation by the committees, but various suggestions for reform may have lead to further criminalization, whether intentional or not.

${ }^{17}$ The Badgley Report, supra note 11 at 1046.

${ }^{18}$ Ibid.

${ }^{19}$ Lowman, supra note 7 at 196.
} 
their ways through the criminal law. Lastly, as with all sanctions against prostitution, a law specifically criminalizing young prostitutes would merely punish and stigmatize them. Rather than protect girls and women working in prostitution, criminal measures instead exacerbate the problem and the violence. Researchers have argued that criminalizing young prostitutes would only serve to entrench youth in prostitution, ignoring the factors that contribute to making prostitution a choice for some youth. ${ }^{20}$

The most surprising recommendations came from the Standing Committee in 1992 in their support of further criminalization. The Standing Committee's first recommendation calling for funding for programs to assist prostitutes, while aimed at providing support and social programs, solely focused on those wishing to leave the trade. It ignored those who wish to remain in the trade. This can be seen as a form of "bargain help" where prostitutes can get help, but only on the condition they reject prostitution. ${ }^{21}$ There were no support or health and safety measures recommended to assist prostitutes working on the streets. This particular recommendation did not address the needs of those choosing to continue to work as prostitutes, implying that only those women who choose to leave prostitution are deserving of assistance. Those who choose to remain are left without access and entitlement to such services. As Lowman points out, "Like nearly all Canadian political rhetoric on prostitution, this recommendation is abolitionist at heart, because it does not countenance harm reduction programs, or any other kind of service for prostitutes." 22

\footnotetext{
${ }^{20}$ J. Jesson, "Understanding Adolescent Female Prostitution: A Literature Review" (1993) 23(5) British Journal of Social Work at 517 at 522.

21 Lowman, supra note 6 .

${ }^{22}$ Ibid.
} 
Their second recommendation, which would permit fingerprinting and photographing of all those charged under section 213 , including prostitutes, would further criminalize them. The Committee was asking for an amendment to the Identification of Criminals Act which stipulates that persons convicted of an indictable offence may be photographed or fingerprinted. ${ }^{23}$ However, communicating for the purposes of prostitution is a summary offence so it does not allow this mode of identification. Summary convictions in Canada are considered minor offences that do not require fingerprinting and photographing. Permitting this change would be a major infringement on the rights of those accused. Suggesting that the Act be amended to single out those charged under section 213 (which would be overwhelmingly female prostitutes) for a more onerous criminal response than applied to other summary offences, targets women in the sex trade and is highly discriminatory. It would be a further form of shaming and criminalization.

While the Government of the day chose not to implement either of these repressive recommendations, it is questionable on what basis the Standing Committee made these recommendations. Research and evidence accepted by the Fraser Committee, the most recent report prior to the Standing Committee indicated that criminalization is not effective in addressing prostitution. What makes the Standing Committee's recommendations even more surprising is that they came shortly after the Federal evaluation of the communicating law involving the five regional studies commissioned by the Department of Justice. These studies clearly documented that criminalization and the enforcement of the current laws were actually exacerbating the "problem" of

\footnotetext{
${ }^{23}$ The Identification of Criminals Act (R.S., 1985, c. I-1).
} 
prostitution and potentially creating unsafe conditions for street level sex workers. ${ }^{24}$ To recommend further criminalization when the evidence clearly showed the ineffectiveness of such measures and the harm it would cause to prostitutes, would seem to indicate a committee mired in sexist views of prostitutes and a committee unwilling to reexamine their assumptions and explore alternatives, even in the face of evidence that required them to do so.

\section{$\underline{\text { Law Reform }}$}

All three reports in their examination of prostitution in Canada cited and acknowledged the problematic nature of Canada's prostitution legislation. In the early 1980's The Badgley Committee noted the very precarious position of juvenile prostitutes under the law. There were no provisions directed specifically at youth prostitution, only general legislation relating to child welfare, sexual offences, and adult prostitution, all of which were inadequate to deal with the unique situation of youth prostitutes. ${ }^{25}$ The Fraser Report, looking at street level prostitution as a whole, was highly critical of the prostitution related offences at the time, mainly the soliciting law. As the Fraser Report states,

This legislation reflects the thinking of earlier generations which saw prostitution and related activities as immoral, the people engaged in these activities as truly depraved or of sub normal intelligence, and always, the danger of innocent women being seduced into the business. ${ }^{26}$

\footnotetext{
${ }^{24}$ See Brannigan, et.al., 1989; Gemme, et.al., 1989; Graves, 1989; Lowman, 1989; Moyer and Carrington, 1989.

25 The Badgley Report, supra note 11 at 950.

${ }^{26}$ Report of the Special Committee on Pornography and Prostitution: Pornography and Prostitution in Canada (Ottawa: Canadian Government Publishing Centre, 1986) at 388.
} 
The situation was no better when the Working Group in 1998 provided a very thorough legal analysis of the new communicating law which replaced the soliciting law. It was just as ineffective as its predecessor. An enormous amount of the Working Group's Report addresses the current legislative provisions relating to prostitution, as well as suggested legal reforms and amendments, and potential effects or consequences if various provisions were enacted or amended. While the Working Group could not reach a consensus on substantive reforms, in terms of legal reform pertaining to street prostitution or increasing the safety of prostitutes, they acknowledged the problems with the current laws, in particular the communicating law, as documented by the studies and additional analysis and reviews conducted independently by other researchers. Time and time again, Committees and Reports have clearly and strongly indicated the very problematic and ineffective nature of the laws, and, in the case of the Fraser Committee, offered recommendations for reform.

\section{The Fraser Report and Decriminalization}

The Fraser Committee brought insightful legal analysis to bear in order to provide a series of forceful policy recommendations and a convincing indictment of the law (the soliciting law) as it stood in $1984 .^{27}$ The Fraser Committee offered the most comprehensive discussion and recommendations on prostitution in Canada. Feminists, women's organizations and civil liberties associations credit it as the most progressive of the reports discussed in this chapter. ${ }^{28}$ One of the Fraser Committee's recommendations

\footnotetext{
${ }^{27}$ Lowman, supra note 3 at 78 .

${ }^{28}$ Emily van der Meulen, Towards More Egalitarian Policies on Prostitution: What Canada Can Learn from the International Community, Conference Presentation (2005). Available at: http://www.sfu.ca/espconference2005/web/presentations/Panel\%20D1.doc
} 
was to identify private locations where prostitution could occur such as small scale commercial prostitution establishments or allowing prostitutes to work out of their residences. To facilitate this, the Committee also recommended repealing the bawdy house laws to allow one or two prostitutes over the age of 18 to employ themselves in a private abode. ${ }^{29}$ Such a strategy would provide a greater level of safety for prostitutes, allowing them the option of working indoors in a controlled environment, rather than on the streets where they are subject to arrest for communicating, and at greater risk of violence. The Committee did not support strengthening legal sanctions noting, "We see no virtue in replacing the present system with a more repressive regime." 30 While the Committee did not support full decriminalization, they did support some form of it:

Although we do not in any way favour people pursuing prostitution as a career, we also believe that adults who determine that they want to pursue that lifestyle and do so without engaging in incidental criminal activity should be able to do so with dignity and without harassment. Accordingly we are of the opinion that the prostitution related activities of prostitutes should be decriminalized as far as possible." 31

This opinion would have more meaning if the Committee was acknowledging the right of prostitutes to pursue their chosen work safely and with respect. However, the use of the term lifestyle minimizes the significance of their insight. Calling prostitution a lifestyle takes legitimacy and respect from the work they do. We do not call teaching, or nursing or engineering a "lifestyle." One's job is usually seen as separate from one's person, however labeling prostitution as a lifestyle unifies the two and implies a judgement, a judgement of character and an assumption that "you are what you do."

\footnotetext{
${ }^{29}$ The Fraser Report, supra note 26 at 538 .

${ }^{30}$ Ibid. at 533.

${ }^{31}$ The Fraser Report, supra note 26 at 534.
} 


\section{$\underline{\text { Alternative Strategies }}$}

Possible interventions outside the criminal law are not adequately addressed in the Badgley Report or the Fraser Report. While the Fraser Committee rightly pointed out that both legal and social reform is required in Canada's approach to prostitution, it is unclear what that is and how that would translate into meaningful reforms and strategies. The Reports overall recognize that prostitution is inextricably tied up in economic and social inequalities but fail to offer substantive recommendations that might address these components.

The Working Group, examining prostitution over ten years after the Fraser Report, did recommend several measures that would positively impact the lives and health of prostitutes working on the streets. The Group cites a need for funding for social programs and intervention strategies, however there is no development of this recommendation and no concrete suggestion on how this is to be done. Additionally, we should be wary of "intervention" strategies as they can be seen or interpreted as "rescue" tactics, reminiscent of the Victorian era, that reinforce the notion all prostitutes are helpless "victims" of the trade, and that only those who are willing to leave, are entitled to services. Strategies such as this do not recognize the ongoing needs of women and

girls who continue to work as prostitutes. Services and assistance in terms of healthcare, housing, training and education, counseling, and drug treatment need to be available for both those leaving the sex trade and for those who remain.

The Working Group also recognized a need to eliminate the mistreatment and discrimination against street level prostitutes, in particular by public and law officials. They note that there needs to be a change in law enforcement practices and in the 
perceptions of prostitutes by legal officials including the judiciary. They found that there is a very wide variation in the treatment given to prostitutes by police. Lack of awareness on the part of criminal justice personnel (police, crown counsel and judges) was cited as a major reason why offences involving pimps and customers were not treated seriously. ${ }^{32}$ In their discussions with sex workers and various groups and individuals who work with sex workers, many respondents across Canada stated that judges should be educated regarding victimization ${ }^{33}$ of prostitutes in order to reduce the differential treatment in sentences between prostitutes and customers. ${ }^{34}$ The problem with recommendations such as these is that while insightful and relevant, if they are not translated into actual policy and initiatives, they are meaningless.

\section{$\underline{\text { Addressing Violence Against Prostitutes? }}$}

While there were no recommendations in any of the reports that specifically speak to the issue of violence, there was recognition that violence is prevalent in the lives of sex workers and needs to be addressed as part of the larger framework of the social and legal reform of prostitution. For example, the Fraser Committee's recommendations on repealing and amending the current prostitution laws indirectly speak to the importance of increasing the safety and well being of prostitutes and providing a safer environment for them to work in. The Working Group addressed the issue directly stating, "Decisions relating to how street prostitution should be addressed must take into account the

\footnotetext{
${ }^{32}$ F/P/T Working Group Report, supra note 14.

${ }^{33}$ To clarify what I mean by victimization in this context and throughout, I am not speaking of sex workers as "victims of the trade" or "victims of prostitution" or "victims of male oppression and sexual exploitation." By victimization I am referring to the harassment, abuse and violence they experience from the public, clients, pimps and legal officials.

${ }^{34}$ F/P/T Working Group Report, supra note 14.
} 
potential for increased violence against prostitutes." 35 While this consideration is crucial, it reads as simply a general statement, rather than a concrete strategy to be enforced. It was not formulated into a recommendation. The hesitancy and lack of consensus present, in particular with the Working Group's recommendations, produced at a time when the issue of abuse and violence in the lives of prostitutes was well known, is disappointing. It signals a lack of political will to engage with a critical issue, for fear of controversy or perhaps irreconcilable differences and opinions among the members. The inability of the Working Group to recommend clear and concise legal reform and strategies to reduce violence and abuse to prostitutes in their working and everyday lives, comes at the cost of rendering the issue irrelevant.

\section{Government Response}

Government reaction to the Badgley Report centered on responding to the public's shock and alarm over the incidence of child abuse, sexual assault and exploitation of youth documented in the Report. Hence, the Government focused on criminalization strategies to prevent youths from engaging in prostitution and assisting them out of it, as well as targeting exploiters and abusers of youth. In issuing its response to the Badgley Report, the Federal Government highlighted what they believed were the important findings of the Committee. It is interesting to note, that in their list of findings, not once did they mention the data and evidence of abuse and violence documented by the Committee. The Government pulled out and cited examples such as "about half the youths came from broken homes" and "most had limited job skills" and "one in four were

\footnotetext{
${ }^{35}$ F/P/T Working Group Report, supra note 14.
} 
frequent users of alcohol and drugs" as crucial findings in the Report. ${ }^{36}$ However, the Government failed to point out the extensive findings relating to violence referenced in the Report. These important points were not included in the list.

The Government also overlooked the evidence of violence against prostitutes presented by the Fraser Committee, choosing instead to focus on what witnesses before the Committee (of whom very few were prostitutes) had asked for. In other words the Government reacted to what the public (i.e. police, neighborhood organizations etc.) wanted, which based on testimony from the Report and reaction to the Report, was the strengthening of the laws against prostitution and removal of prostitutes from communities and neighborhoods. In responding to the Fraser Report and its recommendations, the Government of the day centered their commentary on juvenile prostitution, completely overlooking that the Fraser Report was addressing prostitution as a whole, including both juvenile and adult prostitution. The Government ignored the other critical information that came out of the Fraser Report, such as incidents of abuse and violence, and the inadequacy, and discriminatory nature of the laws. Instead they placed emphasis on developing strategies to prevent young persons from taking up prostitution and finding ways to enable or encourage them to leave prostitution. ${ }^{37}$

Overall, the Government in responding to both the Badgley and Fraser Reports opted to "embark on a course that combines the use of criminal law to prohibit certain forms of conduct which are harmful to others, with supporting social and educational instruments." ${ }^{38}$ In this way, the Government has maintained their historical social and

\footnotetext{
${ }^{36}$ Guide to the Federal Government Response to the Reports on Sexual Abuse of Children, Pornography and Prostitution. (Ottawa: Department of Justice, 1986).

${ }^{37}$ Ibid.

${ }^{38}$ Ibid.
} 
legal response to prostitution, that being the outlawing of women engaged in prostitution, and a reform and rehabilitation approach toward those who are considered "helpless" or do not "know any better." This response renders the other issues (such as the ineffectiveness of the prostitution legislation and the abuse and violence prostitutes experience) invisible. The Government chose to only to respond to issues that are appeasing to the public and to the Government's political agenda, ignoring the more controversial but pressing concerns of prostitutes.

In terms of legislation and amendments, The Canadian Government responded with a range of legal reforms. In 1988, four years after the release of the Badgley Report, legislation was introduced to specifically criminalize child sexual abuse, which included criminalizing the sexual procurement of youth. ${ }^{39}$ In 1997 the procuring and living on the avails sections of the Criminal Code were amended to discourage the exploitation of youth and trafficking for the purposes of prostitution. ${ }^{40}$ Again, these legislative reforms were directed at the issues of youth prostitution and trafficking and did not address the overall issue of abuse and violence. The Federal Government 's only reform of prostitution law in relation to street prostitutes (against the recommendations of the Fraser Committee in particular) has been to revise the street prostitution provision so as to make it easier to enforce. ${ }^{41}$ In December 1985 the soliciting law was repealed and replaced by the communicating law, section 213 of the Criminal Code. ${ }^{42}$ Of significance,

\footnotetext{
${ }^{39}$ Steven, Bittle, Youth Involvement in Prostitution: A Literature Review and Annotated Bibliography. (Ottawa: Research and Statistics Division, Department of Justice, 2002). Available at: www.justice.gc.ca/en/ps/rs/rep/2001/rr01-13.pdf

${ }^{40}$ An Act to Amend the Criminal Code, Bill C-27 1997.

${ }^{41}$ Lowman, supra note 6.

${ }^{42}$ See Criminal Code Appendix for full citation of section 213, the communicating law.
} 
this law made the client as well as the prostitute subject to criminal charges. But it is still mainly women who work as prostitutes and are arrested and charged under the law. ${ }^{43}$

The actions of the Government have reaffirmed its commitment to the criminalization of prostitution and have entrenched the contradictory structure of Canadian prostitution law. ${ }^{44}$ Prostitution itself continues to be legal in Canada and yet communicating for the purposes of prostitution is not. If prostitution itself is legal then where is it allowed to take place and under what terms and conditions? The law is structured in such a way that there is no place and no terms under which a prostitute can negotiate payment for sex, or carry out her trade safely. The abundance of research has shown this legal regime is harmful to the safety and well being of prostitutes who work on the street.

Despite the evidence of discrimination, abuse and misogynistic violence, most recently cited by the Working Group in 1998, the Government refused to publicly acknowledge or address violence against prostitutes. They remained silent on the issue. They have consistently reacted by criminalizing the women who work as prostitutes, moving to strengthen Canada's laws against prostitution rather than exploring alternative solutions. The ineffectiveness of these laws has repeatedly been presented in each and every report and yet the Government continues to follow this same line of response, largely choosing to disregard the recommendations of the committees. Certainly any

\footnotetext{
${ }^{43} 92 \%$ of those sentenced to prison for communicating offences in 2003-2004 were female. Also $68 \%$ of women charged were found guilty under section 213 while $70 \%$ of charges were stayed or withdrawn for men charged under the same provision. (Information provided by Roy Jones, Director, Canadian Centre for Justice Statistics, testimony before the Subcommittee on Solicitation Laws, 16 May 2005; and documentation provided by the Canadian Centre for Justice Statistics, Prostitution in Canada, Statistics Canada, at 12).

${ }^{44}$ Lowman, supra note 6.
} 
recommendations that may have benefited the well being, safety and security of prostitutes, such as those proposed by the Fraser Committee have been ignored.

\section{Re thinking and Re Examining Prostitution and Violence}

Why is violence against prostitutes continually overlooked or treated as secondary? The often cautious and unsure approach exhibited by the committees and the lack of attention and action by the Government, speaks to the continuing discomfort society and politicians have with prostitution. The law and order and moral approaches still guide prostitution policy. Law reform is but one possible strategy to minimize the harm that prostitutes face on the street. The issue stems far beyond criminal law reform into male violence against women, and a history of mistreatment of those involved in sex work. None of the committees picked up on the research and evidence as pointing to a phenomenon of gendered violence, directed at a clearly marginalized group of women, put in precarious and vulnerable situations as a result of societal attitudes and the current legal framework that criminalizes them. Violence against prostitutes needs to be addressed in this context. Inaction on the part of the Government endorses a culture of violence by failing to respond to the many components that create unsafe working conditions for women working as prostitutes.

After all of these major committees and reports, including other subsidiary research and findings, there has been little or no change in either the legal response, and certainly no change in the conditions in which prostitutes work. The abuse, disappearance, and murder of women in the sex trade continues. Possibly in response to this, several initiatives emerged, in an effort to challenge the violence, and their impact remains to be seen. Another Working Group was established, two Charter challenges 
were launched arguing Canada's prostitution laws are unconstitutional, and a Subcommittee on Solicitation Laws was created to examine prostitution legislation and violence against prostitutes.

The Federal Government established The Federal Provincial Territorial Working Group on missing women. The group is comparing best practices in detecting serial murderers, as well as strategies to protect potential victims. ${ }^{45}$ It is geared toward women who live "high risk lifestyles", including sex workers. While not exclusively examining sex workers, much of their research and work have inevitably centered on prostitution and prostitutes, as women in the sex trade make up a large number of the missing women in Canada. The group's findings are expected to be presented sometime in 2008.

The continued advocacy of sex workers and their associated organizations has lead to significant legal challenges. Two reference cases, one launched in B.C, the other in Ontario are challenging Canada's prostitution laws. ${ }^{46}$ With no acknowledgement from the Government that Canada's prostitution laws are ineffective and negatively impact the lives and well being of sex workers, and in turn no action taken by the Government to reform Canada's prostitution laws, the matter will now be considered by Canada's courts. The constitutional challenges relate to three provisions of the Criminal Code, the communicating law, the bawdy house laws and the living on the avails law. The challenges argue that these three provisions violate the Charter of Rights and Freedoms by "depriving sex workers of their right to liberty and security in a manner that is not in

\footnotetext{
${ }^{45}$ Sue Bailey, "Missing Women Working Group" Winnipeg Sun, 15 May 2005, available at: http://www. missingpeople.net/feds to announce new missing wom.htm

${ }^{46}$ See Bedford v. The Queen: Ontario Superior Court Application March 2007 and Downtown Eastside sex workers united against violence v. The Queen: BC Supreme Court Statement August 2007.
} 
accordance with the fundamental principles of justice" ${ }^{\prime 47}$ The goal is to ultimately have the laws struck down, creating an opportunity for decriminalization.

Political will has also materialized. Member of Parliament Libby Davies, a very vocal advocate on violence against prostitutes, tabled a motion in 2003 in the House of Commons, to review the prostitution laws with the aim of improving the safety of sex workers and communities. ${ }^{48}$ The result of this motion was the subcommittee on solicitation laws which presented their report, The Challenge of Change: A Study of Canada's Criminal Prostitution Laws in $2006 .{ }^{49}$ This report is the subject of chapter six of this thesis and is examined separately from the earlier reports and committees, in light of the fact that it was established in response to the previous and ongoing failures of the Government and justice system to take seriously violence against prostitutes as well as the problematic nature of Canada's criminal laws pertaining to prostitution. This report was underway at the time I began writing this thesis. What many women, (including myself) feminists, women in civil rights organizations and sex workers had hoped was that this report would finally offer substantive recommendations and analysis of the culture of violence that has plagued women who work in the sex trade in Canada. With the mounting evidence of the ineffectiveness of the laws and continued incidents of abuse and murder of women working as prostitutes, there was an expectation that this Committee would do what other committees had not been able to do, that is to persuade the Government to finally act to address the violence specifically and directly. The

\footnotetext{
${ }^{47}$ Canadian Charter of Rights and Freedoms, s. 7, Part I of the Constitution Act, 1982, being Schedule B to the Canada Act 1982 (U.K.), 1982, c.11.

${ }^{48}$ Julie Cool, Prostitution in Canada: An Overview (Library of Parliament: Ottawa, 2004). Available at: dsp-psd.pwgsc.gc.ca/Collection-R/LoPBdP/PRB-e/PRB0443-e.pdf

${ }^{49}$ Report of the Subcommittee on Solicitation Laws of the Standing Committee on Justice and Human Rights, The Challenge of Change: A Study of Canada's Criminal Prostitution Laws (December 2006). Available at: http://cmte.parl.gc.ca/Content/HOC/committee/391/just/reports/rp2599932/justrp06/sslirp06e.pdf
} 
following chapter examines this report, the Government's response to it as well as other related emerging material and reactions. 


\section{Chapter Six}

\section{The Challenge of Change}

After numerous reports and millions of dollars dedicated to solving the "problem" of prostitution, very little has changed. One striking and alarming fact that continues to get reiterated in these committees, their reports, and the research and evidence accumulated, is that females who work on the streets as prostitutes in Canada are targeted victims of violence. Despite this, the issue has been largely avoided and overlooked by every government to which these reports and this information have been delivered. While Government chooses to ignore the victimization of sex workers, women in the sex trade continue to work in unsafe conditions, with a very real fear for their wellbeing and their lives. The Government and public have been presented with knowledge and evidence of violence against sex workers, and in some cases, with recommendations and suggestions designed to address this violence. The response has either been further criminalization of women working as prostitutes, or silence in the form of no response at all to the abuse and murder of hundreds of women working as prostitutes in Canada.

Since the Canadian Government last looked at the issue of prostitution with the Working Group's Report in 1998, the abuse, abduction and murder of women who work in the sex trade have persisted. While disappearances, abuse and murders have increased, so too has public attention and concern about the issues. Finally in 2003 Member of Parliament for Vancouver East, Libby Davies, tabled a motion to "review the solicitation laws in order to improve the safety of sex trade workers and communities overall, and to recommend changes that will reduce the exploitation and violence against sex trade 
workers." As an MP in an area that has a large population of prostitutes, and where most of the prostitutes who were murdered and are missing in Vancouver worked, Davies is familiar with the effects of criminalization, discrimination, stigmatization and violence against sex workers on the streets. This reality, combined with an ever increasing number of murdered and missing women in other major Canadian cities, resulted in the political will to examine prostitution and prostitution laws yet again, this time, motivated by, and with a direct focus on the safety of prostitutes. This constituted a significant change in focus from previous reports.

\section{Mandate and Process}

A Subcommittee on Solicitation Laws was set up by the Standing Committee on Justice and Human Rights in response to MP Davies' motion. This Subcommittee began their work in October 2003, but was unable to complete their report due to the prorogation of Parliament. A new Subcommittee on Solicitation Laws was then formed in June 2006, and continued the work of its predecessor maintaining the same mandate and process. This 2006 Subcommittee was composed of six members: two members of the Conservative Party, two members of the Liberal Party, one member of the Bloc Quebecois party and one member of the New Democratic Party. The process involved in carrying out its mandate was similar to that of previous committees. The Subcommittee reviewed the relevant literature and heard testimony from approximately 300 witnesses at public and private hearings and meetings in Ottawa, Toronto, Montreal, Halifax,

\footnotetext{
${ }^{1}$ Report of the Subcommittee on Solicitation Laws of the Standing Committee on Justice and Human Rights, The Challenge of Change: A Study of Canada's Criminal Prostitution Laws (December 2006) at 2. Available at: http://cmte.parl.gc.ca/Content/HOC/committee/391/just/reports/rp2599932/justrp06/sslirp06e.pdf
} 
Vancouver, Edmonton and Winnipeg. Those who appeared before the Subcommittee included dozens of researchers, academics, policy experts, private citizens, social service and health care workers, lawyers, police officers and persons involved in prostitution as well as those representing advocacy associations and non governmental associations. ${ }^{2}$ All testimony and submissions to the committee were made available on the Parliament of Canada website. I include references and quotes from some of these testimonies and presentations, even though they were not included in the Report. The Subcommittee's final report titled, The Challenge of Change: A Study of Canada's Criminal Prostitution Laws, was released in December 2006. This chapter provides an analysis of the Subcommittee's report, and of the Government's official response, in the context of the findings and numerous reports that preceded it.

\section{Something New?}

Three things make this subcommittee distinct from preceding committees. One, the Subcommittee does not examine juvenile prostitution. They state, "It should be noted at the outset that our report pertains exclusively to adult prostitution." ${ }^{.3}$ While the Subcommittee does in places touch on the involvement of children in prostitution, this issue is not included in their mandate and the issue is not discussed anywhere at length in the Report. They acknowledged that it is a separate issue requiring separate examination. Their decision to exclude it from their mandate allowed more of the focus to remain on street prostitution and violence against prostitutes as a whole.

\footnotetext{
${ }^{2}$ Ibid at 2.

${ }^{3}$ Ibid at 1 .
} 
Second, unlike previous committees, the mandate of the new Subcommittee included a specific examination of the criminalization of prostitutes and violence against prostitutes. The explicit goal was to address the safety of sex trade workers and to make recommendations that would reduce the violence. However, while significant and an improvement from previous mandates, this focus was undermined somewhat because it was not made the exclusive focus. What then brings the Subcommittee's approach back to being much like the others before it is the dual focus on the harm to communities and the harm to prostitutes. In such a context the issues of sex workers inevitably take second place to those of the "community." The Subcommittee heard from concerned and interested citizens and groups in person at the hearings and through submitted testimony and briefs, and gave these concerns a great deal of weight. The Subcommittee noted that an important part of their work was speaking to residents who were exposed to the harmful aspects of street prostitution, explaining that the residents provided a balance to the testimony heard by the Subcommittee, helping it carry out its mandate and in turn, address the needs and concerns of prostitutes and Canadian communities alike. ${ }^{4}$

The third distinctive thing to note with reference to the work of the Subcommittee, and the actual content of the Report, is that there is a very strong "sex worker voice" throughout the Report. There was a strong voice in the written submissions made to the Subcommittee and the oral testimonies heard, that was then incorporated in the actual Report. The Subcommittee acknowledged that "The life experiences of these individuals, the problems they face and the solutions they recommend to reduce exploitation and violence in prostitution were extremely valuable

\footnotetext{
${ }^{4}$ Ibid at 3.
} 
and informative." This sex worker perspective and voice were not as evident or influential in previous reports on prostitution. Their inclusion added greater legitimacy to the substance of the Report and provided substantial insight into the discussion on violence.

\section{Report Overview}

The report, The Challenge of Change: A Study of Canada's Criminal Prostitution Laws is divided into seven chapters and like its predecessors, provides a very detailed and thorough examination of prostitution in Canada. It is a well organized and informative report. It covers all aspects of prostitution and those involved in prostitution plus related issues and concerns. It does so in an unbiased and neutral manner while making sure to highlight the many differing perspectives and opinions of those who participated in the Subcommittee's review. Much of this background information on prostitution and prostitutes in general informs the discussion on violence. This is useful because one needs to understand the activity, its history, its context, and the social, legal and political implications of it, in order to examine the violence that has always been associated with prostitution.

Chapter One of the Report provides an introduction discussing the mandate and review process of the Subcommittee. Chapter Two provides a profile of prostitution in Canada discussing the various types of prostitution, and what we know about those who engage in prostitution. Important considerations that arise out of this chapter are the prevalence of Aboriginal women in prostitution and the debunking of myths and stereotypes about prostitutes, such as they are all poorly educated or drug addicts.

\footnotetext{
${ }^{5}$ Ibid.
} 
However, there are many women involved in street prostitution who do have serious drug habits, and the Subcommittee notes that these women are more likely to be targeted by serial killers. ${ }^{6}$

The "harm" of prostitution was addressed within the broader context of Chapter Three, which looks at prostitution and its effects on women who work as prostitutes, and the effect prostitution and its related activities have on the communities in which it occurs. In this chapter, the Subcommittee refers to two distinct kinds of harm related to prostitution - the harm of prostitution on the prostitutes themselves and women generally, and secondly the harm to the communities in which prostitutes work. The discussion of the "harm" to prostitutes reflects the feminist perspective that views prostitution as exploitive and emotionally, psychologically and physically damaging to the women involved. This language however has been picked up by the right wing to support their rejection of prostitution as immoral. Following every other committee before them, the Subcommittee also addressed harm in terms of harm to communities, that being the effects of prostitution related activities in residential and business neighborhoods. ${ }^{7}$

The harm to women perspective was presented from the points of view of those who regard prostitution as an act of violence against all women, and see prostitution as harmful to those who engage in it. Researcher Jacqueline Lynn explained,

We would understand that the process whereby a prostituted woman comes to view herself as product and merchandise is the worst form of dehumanization imaginable, and that prostitution in all its forms is sexual assault against all women and a violation of their basic human rights. ${ }^{8}$

\footnotetext{
${ }^{6}$ Ibid at 16.

${ }^{7}$ See discussion on use of the term "harm" in chapter one of this thesis, supra at 17-18.

${ }^{8}$ Report of the Subcommittee on Solicitation Laws, supra note 1 at 39.
} 
In this discussion of harm, the Subcommittee did not distinguish between these exploitation "harms" and an alternative definition of "harm" that would focus on the harm of violence against prostitutes that is discrimination, abuse, harassment, rape and murder. However the Subcommittee did include perspectives that reject the notion of prostitution as exploitive. The Subcommittee points out that there are many who strongly challenged this view, mainly sex workers, advocates and academics, also noting that most of the sex workers who appeared before the Subcommittee refused to be labeled as victims and rejected the description of their work as violent or as a form of oppression. ${ }^{9}$

The Subcommittee noted that a majority of witnesses (mainly.citizens groups and law enforcement) touched on the problems and nuisances associated with prostitution that affect their neighborhoods. These problems include abusive behaviour toward residents, traffic of cars, harassment of residents by clients, used condoms and needles and noise. ${ }^{10}$ These same concerns had been voiced in previous reports. While in this Report the discussion pertaining to community harms did not overshadow the issue of violence, it nonetheless shifted the focus away from the violence issue. As I addressed in Chapter four and five of this thesis, previous reports such as the Fraser Report, discussed at length neighborhood concerns with prostitution, and the Working Group's Report in 1998 examined community harm and harm to prostitutes together. No effective strategies or changes had materialized from either of these reports.

Concerns about the harms and nuisances neighborhoods face are legitimate, but seen against the very urgent and pressing issue of marginalized women being abused and murdered in large numbers, they are not comparable problems. The Subcommittee

\footnotetext{
${ }^{9}$ Ibid at 35 .

${ }^{10}$ Ibid at 29.
} 
seemed more interested in a "balanced" presentation of the harms related to prostitution, rather than acknowledging the serious imbalance with respect to the impact and severity of these harms. Balance, like "neutrality" generally operates to further disadvantage and marginalize the already marginalized. The concerns of prostitutes, heard through the engrained myths, stereotypes and assumptions about prostitution, cannot compete with the concerns of ordinary "innocent" law abiding citizens. In light of the very real issue of violence and abuse directed at women working on the streets, the harms they experience should take precedence. In addition, if we seriously address this violence, we may in doing so eliminate some of the negative impacts prostitution has on communities.

If we addressed the safety of prostitutes first, we might for example, decide that an effective strategy would be to designate areas where prostitutes can work, or more importantly, allow prostitutes to work indoors, out of their homes, or out of hotels, without fear of arrest or charge. This would move prostitutes off the streets of residential neighborhoods. It would be unrealistic to assume that no prostitutes would continue to work on the streets if alternatives were available, but it would significantly reduce the presence of prostitution on the street, thereby to some degree addressing a number of the concerns residents have with prostitution in their neighborhoods.

Chapter Four of the Report discusses the legal response to prostitution, outlining the troubled history of Canadian prostitution law which evolved from social and moral reform movements into the present legislation. ${ }^{11}$ Specifically addressing section 213 of the Criminal Code, the Subcommittee states, "Nearly all witnesses stated that section 213 is not an effective tool for achieving the Subcommittee's mandate relating to the safety of

\footnotetext{
${ }^{11}$ Refer back to chapter two of thesis which outlines the history and implementation of Canada's current prostitution legislation.
} 
prostitutes and communities."12 This chapter leads into the discussion of the impact of the law in Chapter Five, which was a very important part of their mandate, in terms of how the laws affect the health and safety of sex workers. I provide more detail on this below in the discussion on violence.

Chapter Six examines how other countries have met some of the legal challenges surrounding prostitution. The Subcommittee looks at models for reform, something both the Fraser Committee and the Working Group had done as well, taking evidence from other countries. Specifically, the Subcommittee explores the Swedish model where clients are criminalized, New Zealand and parts of Australia where decriminalization has been implemented, and finally models of legalization and regulation in Germany, Nevada, Netherlands and some states in Australia. The Report delves into the debates surrounding these models, and presents the anticipated, as well as evidenced, pros and cons of each model.

Much of the information reported in The Challenge of Change was contained in preceding reports. By the time of this most recent report, prostitution has become a much studied issue. New research, literature, studies and data have emerged in the 10 years since the Working Group's last report in 1998. While this recent data and information do not reveal anything new about the situation of violence against prostitutes, they do reinforce the severity and prevalence of the violence and support previous research and arguments. Much of the material presented and discussed in the Report is a repeat of what was provided in the Badgley, Fraser and Working Group Reports. In what follows, I will not go into a great deal of detail on the material presented in the Report as this would largely be a rehash of my previous chapters, just as the Challenge of Change was

\footnotetext{
${ }^{12}$ Ibid at 52.
} 
largely a rehash of the preceding reports. I will however, highlight the discussion on violence and the input provided by sex workers. I then look at the final chapter of the Report, Chapter Seven, which outlines the seven recommendations issued by the Subcommittee in their conclusion.

\section{Violence: A Shared Experience}

Section Four of Chapter Two specifically addresses violence in the lives of street prostitutes. The Subcommittee points to the sadistic murders of a number of prostitutes, mainly in the cities of Vancouver and Edmonton, as creating awareness among the public about the violence that prostitutes face. However, the Subcommittee rightly points out that this violence is not new nor is it restricted to the areas of Vancouver and Edmonton. ${ }^{13}$ It is a national and global phenomenon among women who work in the sex trade. The Subcommittee notes,

People who engage in prostitution, particularly street prostitution are faced with many different types of abuse and violence, ranging from whistles and insults to assault, rape and murder. This violence comes from clients, pimps, drug dealers, members of the public, and police officers. ${ }^{14}$

The Report outlines the numerous works and studies of researchers who have examined violence against prostitutes in depth. Sex workers and sex workers' organizations commented on the combination of factors that fuel the discrimination and violence. Kyla Kaun, director of public relations for Vancouver's Prostitute's Empowerment Education Resource Society (PEERS) explains, "The stigmatization of prostitutes exposes them to various forms of violence. They are often regarded as criminals and second class citizens, and some people feel justified in humiliating them,

\footnotetext{
${ }^{13}$ Ibid at 17.

14 Ibid.
} 
harassing them, and throwing things at them, and even physically abusing them." goes on to note the role media plays in this explaining "It's all those awful images they put out there that make us look at them and say "why would we want to save that life?"16

\section{Violence and the Criminal Law}

An important part of the Subcommittee's mandate was analyzing the impact of criminal laws concerning prostitution on the health and safety of sex workers, concerns previously raised in both the Fraser Report and Working Group's Report. Chapter Five of the Subcommittee's Report examines this effect. They acknowledge John Lowman's study of the communicating law and the impact the law has had on the levels of violence prostitutes have experienced since its enactment in 1985. Witness testimony and the literature concerning the impact of prostitution laws on the health, safety and well being of prostitutes speaks to this as well. The existence and enforcement of the prostitution provisions of the Criminal Code are cited by many in the Report as contributing significantly to an unsafe environment for sex workers, an environment conducive to abuse, exploitation and isolation. ${ }^{17}$ The indication is that criminalization intended to control prostitution related activities in Canada jeopardizes the safety of prostitutes as well as their access to health and social services. ${ }^{18}$

An alternative perspective on the negative affects of criminalization was presented by those who view criminalization as important in the broader campaign

\footnotetext{
${ }^{15}$ Ibid at 20 .

${ }^{16}$ Ibid.

${ }^{17}$ See specifically the testimony of Frances Shaver, Deborah Brock, Jennifer Clamen, and Raven Brown, which can be found at:

http://cmte.parl.gc.ca/cmte/CommitteePublication.aspx?SourceId=127135\&Lang=1\&PARLSES=381\&JNT $=0 \& \mathrm{COM}=9243$;

${ }^{18}$ Report of the Subcommittee on Solicitation Laws, supra note 1 at 61.
} 
against pimps and clients. This view was mainly supported by law enforcement. According to a number of police officers who testified, the enforcement of section 213 offers them the opportunity to protect prostitutes from a drug habit, pimps and the "inherent dangers" of prostitution. ${ }^{19}$ Additionally for some, the criminal law is seen as a form of social intervention that could assist women in exiting the trade. ${ }^{20}$ In this way, the criminal law is seen as a tool that, as one officer explained "can be used to compel young women to seek or take advantage of resources that may help them exit the trade, such as a probation that requires them to meet with a counselor who can help them develop exit strategies." ${ }^{21}$ But there is no data or evidence that either of these goals has been, or can be accomplished by criminalization. This particular strategy has been unsuccessful since the era of moral reformers. ${ }^{22}$ To date, the law has been ineffective in deterring clients, pimps or prostitutes. In 1990 the Standing Committee on Justice and Human Rights presented the findings of a three year review of the communicating law. In Toronto and Vancouver, the two sites with the highest incidence of street prostitution, it was determined that, "despite vigorous law enforcement, considerable costs, and the near certainty of conviction, the incidence of street prostitution in Vancouver and Toronto was not reduced., 23

The Subcommittee spends very little time discussing any positives associated with criminalization, acknowledging the differing opinions, but citing that there was much agreement that the most marginalized individuals experience the negative consequences

\footnotetext{
${ }^{19}$ Ibid at 69.

${ }^{20} \mathrm{Ibid}$.

${ }^{21} \mathrm{Ibid}$

${ }^{22}$ See chapter two of this thesis at 37-38.

${ }^{23}$ Standing Committee on Justice and Human Rights Fourth Report (respecting soliciting for the purpose of prostitution). Minutes of Proceedings, Issue No. 42, 4 October 1990.
} 
of criminalization. ${ }^{24}$ Kate Gibson executive director of the WISH drop in center sums up the overall problem with criminalization for prostitutes and communities:

Criminalization of sex workers in no way addresses the health and safety of an individual or a community. What criminalization does is jeopardize the health and safety of the sex worker and isolates that person from the rest of society. Isolation causes fear, low self esteem and desperation, all symptoms that make sex workers more and more vulnerable to predators and violence"

She concludes with a chilling reminder, "surely we have seen enough of what a single predator can do."26

\section{Sex Worker, Sex Worker Organizations, and other Feminist Perspectives}

Raven Bowen, of the PACE society, in her testimony to the Subcommittee stated, "We want this Subcommittee to adopt as a basic principle that whatever discussion happens around this, you include the individuals most affected by the issue in the creation of its solution." 27 Since the goal of the Report was to address the wellbeing and safety of sex workers, it was critical to hear about their first hand experiences in the industry. Prostitutes can speak directly to the realities of sex work, and most importantly to violence in the trade. Most of the sex workers who provided testimony and submissions to the Subcommittee view themselves as workers, the services they provide as work, and the violence they experience as a violation of their occupational and human rights.

\footnotetext{
${ }^{24}$ Report of the Subcommittee on Solicitation Laws, supra note 1 at 70.

${ }^{25}$ Testimony of Kate Gibson to the Subcommittee on Solicitation Laws of the Standing Committee on Justice and Human Rights, Public Safety and Emergency Preparedness. Number $017,1^{\text {st }}$ Session, $38^{\text {th }}$ Parliament, 29 March 2005. Available at: http://cmte.parl.gc.ca/cmte/CommitteePublication.aspx?Sourceld=127180\&Lang=1\&PARLSES=381\&JNT $=0 \& \mathrm{COM}=9243$

${ }^{26}$ Ibid.

${ }^{27}$ Testimony of Ms Raven Bowen to the Subcommittee on Solicitation Laws of the Standing Committee on Justice and Human Rights, Public Safety and Emergency Preparedness. Number $017,1^{\text {st }}$ Session, $38^{\text {th }}$ Parliament, 29 March 2005. Available at: http://cmte.parl.gc.ca/cmte/CommitteePublication.aspx?SourceId=127180\&Lang=1 \&PARLSES=381\&JNT $=0 \& \mathrm{COM}=9243$
} 
Many groups and organizations who conduct research with sex workers, provided comprehensive reports or submissions to the Subcommittee, based on their work and studies. Sex Trade Advocacy and Research (STAR) was one such organization. Their report Safety, Security and the Well Being of Sex Workers, identified some of the risks to safety and security encountered in various sectors of the sex industry, the factors contributing to these risks, and the legislation and policies that influence the work environment. ${ }^{28}$ The STAR report also provided some recommendations for improving the work environment and providing education, advocacy and support. ${ }^{29}$ Pivot Legal Society, a non-profit advocacy organization in Vancouver produced two reports. One titled Voices for Dignity is a call to end harms against street level sex workers with a focus on the legal context of prostitution that contributes to these harms. ${ }^{30}$ The other Report Beyond Decriminalization analyzes the range of regulatory frameworks that could be implemented if prostitution was decriminalized. ${ }^{31}$

There were, of course, feminists and women's groups who offered conflicting testimonies and alternative opinions and insights on the issues before the Subcommittee. There are many feminists and women who wish to see violence eliminated. Based on their assumption that prostitution is itself a form of violence against women, they argue that the only way to address the harm is to eliminate prostitution. Among those who share this perspective are those who support criminal prohibitions on sex work (but not necessarily sex workers themselves) to achieve these ends. In particular there are

\footnotetext{
${ }^{28}$ Sex Trade Advocacy and Research (STAR), Safety, Security and the Well Being of Sex Workers: A Report Submitted to the House of Commons Subcommittee of Solicitation Laws (July 2006). Available at: http://web2.uwindsor.ca/courses/sociology/maticka/star/pdfs/safety and security report final version.pdf. ${ }^{29}$ Ibid.

${ }^{30}$ Pivot Legal Society, Voices for Dignity (March 2004). Available at: http://www.pivotlegal.org/Publications/reportsvfd.htm

${ }^{31}$ Pivot Legal Society, Beyond Decriminalization: Sex Work, Human Rights, and a New Framework for Law Reform (2006). Available at: http://www.pivotlegal.org/Publications/reportsvfd.htm
} 
feminists who believe that eliminating the demand side of the industry (criminalizing the clients, not prostitutes whom they see as victims) will eliminate prostitution. ${ }^{32}$ This tension between the perception of "sex work as victimization" and the perception of "sex work as work" informed the entire report, reflecting what the HIV/AIDS Legal Network termed a "simplistic dichotomy" and resulting in the Subcommittee getting caught up in an unproductive debate. ${ }^{33}$ While presenting only these two diametrically opposed perspectives does not accurately reflect the spectrum of sex work and violence against sex workers positions, the discussion did nonetheless highlight that there is actually consensus among these differing positions and perspectives, that prostitutes should not be subjected to violence, and a common desire to see this violence addressed. The disagreement lies in the question of how and why we should go about doing this. In this context, sex workers provided critical and persuasive arguments and insights on the social, economic, legal and political implications of prostitution and on strategies to minimize and eradicate violence against sex workers.

\section{Challenging the Violence}

It is clear that what has been done to date does not work and that doing more of the same will not work. Academics and researchers, as well as social and health agencies and other organizations outlined numerous approaches to challenge violence against prostitutes. Sex workers themselves put forth innovative strategies to address the violence. These initiatives had a common framework. The proposed strategies range

\footnotetext{
${ }^{32}$ Report of the Subcommittee on Solicitation Laws, supra note 1 at 69.

${ }^{33}$ Canadian HIV/AIDS Legal Network, Not Up to the Challenge of Change: An Analysis of the Report of the Subcommittee on Solicitation Laws (February 2007). Available at: http://www.aidslaw.ca/publications/interfaces/downloadFile.php?ref $=975$ at 3.
} 
from short term to long term, from detailed to broad, but together they provide a comprehensive multidisciplinary approach that challenges the legal, social and political barriers that prevent us from understanding prostitution and thus from understanding violence against prostitutes. They asked the Subcommittee to again consider legal reform, but also more innovative initiatives. One example was educating the public, judiciary and law enforcement about prostitution, and about the discrimination, stigma and bias that contribute to violence and abuse. This strategy had also been put forward by the Working Group in 1998. Such a strategy highlights why focusing on the debates between decriminalization and legalization is relevant, but should not be the focus. Significantly, the decades of dialogue about these legal responses has not yet achieved anything. We have not been able to get the Government to act in the face of the continued polarization of the issue. We need more than legal reform and debate to address the violence. Legal reform alone will not counteract decades of imbedded moralism, discrimination and stigma in our society. We can change the laws, but that will not change attitudes right away; much more is required. Education and training initiatives are good examples of what more can be done.

Sex workers, individuals and groups provided concrete measures to create harm reduction strategies designed to challenge exploitation, abuse and violence. These proposed strategies included decriminalizing all or parts of the prostitution legislation, using existing legislation in the Criminal Code to protect sex workers from abuse and violence, and economic and social changes via community based organizations as they are in the best position to assist in designing and implementing such changes. ${ }^{34}$ Testimonies from these organizations were compelling and powerful. Jenn Clamen with

\footnotetext{
${ }^{34}$ Sex Trade Advocacy and Research (STAR), supra note 28 at 32.
} 
the Coalition for the Rights of Sex Workers summed up why "we are here" from a sex worker perspective when she concluded, "This Subcommittee was initiated to ensure that sex workers, as citizens are no longer denied their human rights." ${ }^{35}$ Human rights were, at least in part, the context of this Subcommittee. It was the Standing committee on justice and human rights that gave this Subcommittee its mandate, signaling, symbolically at least, a concern over the basic human rights of sex workers. Whether or not sex workers will be fully accorded these rights still remains to be seen.

As a whole, this Report simply does more of the same in terms of what other reports have done in the past, granted, with an increased focus on the issue of violence and far greater sex worker input. The most crucial part of the Subcommittee's mandate was to recommend changes that would reduce the exploitation of and violence against sex trade workers. This is where the Report most certainly fails.

\section{Recommendations}

The title of the Subcommittee's concluding chapter, "Difficulties in achieving consensus" clearly indicates what is to follow in the recommendations, and reflects a common theme on the issue of prostitution in general. At the outset, the Subcommittee states, "...there is little consensus surrounding the issue of adult prostitution..."36 They proceed to set out the only two points of agreement reached by the Subcommittee. One: "The Subcommittee does agree that violence, discrimination and intimidation against

\footnotetext{
${ }^{35}$ Testimony of Jenn Clamen to the Subcommittee on Solicitation Laws of the Standing Committee on Justice, Human Rights, Public Safety and Emergency Preparedness. Number 033, First Session, $38^{\text {th }}$ Parliament, 30 May 2005. Available at: http://www2.parl.gc.ca/search/SearchResults.aspx?Language=E\&Parl=\&Ses=\&Ct=wwwparl\&search secti on=main\&search term $=$ Jenn+Clamen\&institution=any \& forparl=Parliament $\% 5 \mathrm{~B} \% 2738 \% 27 \% 5 \mathrm{D} \% 3 \mathrm{BSess}$ ion $\% 5 \mathrm{~B} \% 271 \% 27 \% 5 \mathrm{D} \&$ section=any\&sort=RD

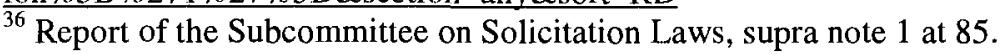


individuals selling sexual services must never be tolerated"37 While this is an important point, it should be a given. There is very little substance to this agreement; it does not carry much weight unless it materializes into an actual strategy to address the abuse, violence and discrimination. It is not apparent that this agreed upon position had any impact on the Subcommittee's conclusions or recommendations.

The second point of consensus surrounds juvenile prostitution. They point out that there is "unanimous agreement that the sexual exploitation of minors through prostitution must not be tolerated"38 Although not without its complexities, juvenile prostitution has consistently been an issue upon which past committees have all agreed. This is a gratuitous, easy point of agreement that is largely irrelevant to the goals and work of the Subcommittee. In bringing this issue to the fore as a point of agreement, the Subcommittee seems to have reverted to "safe territory." Juvenile prostitution is a much easier issue to deal with, one that is not as challenging or controversial as many of the issues the Subcommittee was asked to consider. This was one issue on which they could attain consensus. Accordingly, juvenile prostitution becomes a key point of agreement, even though it was not part of the mandate of the Subcommittee and was not taken up in their Report.

Having established their points of agreement, the Subcommittee proceeds to issue a total of seven recommendations, involving legal, social and economic reforms, short term and long term strategies, plus further research and studies. I will examine each recommendation individually, focusing on recommendation seven, the only recommendation intended to speak directly to the issue of violence.

\footnotetext{
${ }^{37}$ Ibid at 89.

${ }^{38}$ Ibid at 85 .
} 
Recommendations one and two pertain to minors and trafficking in persons. The Subcommittee asks that the Government continue to ensure that the exploitation of minors remains a crime and is subject to severe penalties, and that the problem of trafficking in persons remains a priority, that victims are assisted and traffickers are brought to justice. ${ }^{39}$ The fact that these two issues were not part of the mandate, and were only touched upon briefly in the actual Report, raises the question of why these two recommendations were even issued. This point is echoed by the Canadian HIV/AIDS Legal Network:

Making grand, morally charged pronouncements about sexual exploitation of minors and trafficking in persons was perhaps politically easier for the Subcommittee than confronting the complex and difficult matter of protecting, promoting and fulfilling the human rights of the vast majority of sex workers. ${ }^{40}$

These two recommendations seem to be there merely to reiterate what previous Reports and studies have already said on juvenile prostitution and trafficking. They are meaningless recommendations both because they are neither specific nor concrete, and because there is already consensus from the Subcommittee, from the public and from the Government that juvenile prostitution and trafficking are social concerns for Canadians. Basically two of the seven recommendations of this Subcommittee are recommendations to maintain the status quo on issues that the Subcommittee was not asked to address.

The Conservative Government's official comments on all of the recommendations were delivered in a six page response by Justice Minister Robert Nicholson. ${ }^{41}$ In response to the first two recommendations, he outlined the current Criminal Code

\footnotetext{
${ }^{39}$ Report of the Subcommittee on Solicitation Laws, supra note 1 at 86.

${ }^{40}$ Canadian HIV/AIDS Legal Network, supra note 30 at 4.

${ }^{41}$ Minister of Justice Robert Nicholson, Government Response to the Sixth Report of the Standing Committee on Justice and Human Rights. (2006). Available at: http://cmte.parl.gc.ca/cmte/CommitteePublication.aspx?COM=10474\&Lang=1\&Sourceld=199347
} 
provisions, and strategies and initiatives pertaining to child sexual exploitation and trafficking in persons, to remind the public of the Government's efforts to raise awareness and address these issues. Two pages of the Government's six page response are dedicated to these two concerns. The Subcommittee's and the Government's response attempt to divert attention to the safe, the easy, and the non-controversial.

Recommendation three states, "The Subcommittee recommends that the Government of Canada recognize that the status quo with respect to prostitution is unacceptable, and that the laws that exist are unequally applied..."42 They ask the Government to amend the current laws on prostitution as the laws do not effectively address or prevent the exploitation and abuse occurring in prostitution, nor do they prevent or address the harm to communities. ${ }^{43}$ This is not a new recommendation. The previous reports all acknowledged that the laws do not address the exploitation and abuse of prostitutes. The Subcommittee does not go any further than these prior statements; the Subcommittee does not specify how or in what way the Government should amend the laws. Legislative amendments are an obvious recommendation in light of the compelling evidence cited in this Report as well as the previous reports, on the ineffectiveness of Canada's prostitution laws, for communities, prostitutes and law enforcement. Experts and researchers have been advocating for the repeal and or reform of Canada's prostitution laws for decades, most importantly because they are discriminatory and threaten the health, wellbeing and lives of prostitutes. This recommendation only reiterates what we already know.

\footnotetext{
${ }^{42}$ Report of the Subcommittee on Solicitation Laws, supra note 1 at 86 .

${ }^{43}$ Ibid.
} 
While the recommendation is weak, it does at least point to the need for law reform. The Government's response to this recommendation, a recommendation supported by years of research and evidence, is once again to ignore the advice, and refuse to change the laws, instead opting for stronger enforcement of the laws known to be ineffective. It is obvious the Government's retention of the criminalization of prostitution is about their continued belief that prostitution is immoral. They defend their action or rather lack of action by stating that "The Criminal Code of Canada's solicitation laws are one tool available to law enforcement to protect those involved in prostitution from exploitation and abuse. ${ }^{, 44}$ They do not explain how a law that criminalizes women involved in prostitution could possibly protect them. They make this statement in the face of overwhelming evidence that clearly demonstrates that rather than protect, the law actually exposes prostitutes to abuse and violence. The Report to which they are responding unequivocally documents the ineffectiveness of the current laws.

Justice Minister Nicholson on behalf of the Conservative Government goes on to acknowledge that there are discriminatory practices present in the enforcement of the law (i.e. female prostitutes are arrested more frequently than male clients). His response to this problem is: "we are committed to continuing to work with Provincial and Territorial partners, and with various police associations, to strengthen consistency in enforcement." ${ }^{45}$ The consequences of such a focus on enforcement would unlikely have a positive effect on sex workers. Criminalizing and targeting clients in no way addresses the needs and safety of prostitutes who will continue to work in isolated areas and continue to be arrested and sentenced under the current legal framework. While some

\footnotetext{
${ }^{44}$ Nicholson, supra note 41 .

${ }^{45}$ Ibid.
} 
clients may stop purchasing sexual services, they will likely eventually come back, and those remaining may be far more dangerous. ${ }^{46}$ Clients at risk of arrest may drive prostitution further underground.

Recommendation four asks the Government to develop campaigns and programs to prevent people from entering into prostitution because of lack of choice or coercion and to raise awareness among young people of the risks of being coerced into prostitution. While this may re-direct some youth and individuals who are forced into prostitution, it does not address the needs of those who are currently working as prostitutes or those who choose to remain or choose to become sex workers. In a political and social environment that has seen drastic funding cuts to women's and social welfare programs, the likelihood of adequately funded programs that would offer meaningful alternatives seems remote. ${ }^{47}$

This particular recommendation raises some of the underlying issues of how and why prostitution exists, and even flourishes. But the Government is not willing to look at the larger issues of racism, social and economic inequalities and the feminization of poverty that make prostitution a necessity or a viable option for many women. These are the issues that need to be tackled if one really wants to deter women from working as prostitutes. Campaigns and programs directed towards getting prostitutes to leave prostitution, or not enter it do not address the social and economic issues these women face. For example, putting money into creating and providing alternative jobs for these women would be a much more realistic and effective strategy than merely funding

\footnotetext{
${ }^{46}$ Shannon, Esther, Prostitution-Murders, online posting, 14 December 2006, PARL@LISTSERV.UNB.CA

${ }^{47}$ For example, the $\$ 5$ million dollar funding cut by the Conservative Government to the Women's Program of Status of Women Canada in 2006.
} 
programs to counsel them out of prostitution into a workforce where there are no jobs for them.

In response to this recommendation the Federal Government called for educational strategies and programs to assist women out of prostitution. ${ }^{48}$ The Government also recommended a system for prostitutes,

in which first time offenders or those forced or coerced into prostitution are assisted out of it, and avoid a criminal record, however those who freely seek to benefit from the business of prostitution would be held accountable for the victimization which results from prostitution as a whole. ${ }^{49}$

This is the treat-prostitutes-either-as-victims-or-criminals approach that maintains the deviant victim identity that haunts prostitutes. Only those who are willing to "learn from their mistakes" or recognize their victimization and leave prostitution are entitled to assistance. This leaves those who remain to be labeled and treated as criminals. This dichotomizing attitude has been applied since the Victorian era. It is time for change.

Recommendation five asks the Government to fund research on prostitution in order to obtain a clearer picture of prostitution activities, the associated problems and the needs of people involved. ${ }^{50}$ The Subcommittee believes that a better understanding of the causes and impacts of prostitution is essential. ${ }^{51}$ This recommendation is perplexing for several reasons. One, was this not the point of the Report itself? If anything, the Report is a comprehensive document that presents a tremendous amount of research on prostitution. The Subcommittee fully addresses at length the debates, issues and information on the subject matter. Second, over the last few decades extensive research has been done. As one feminist rightly asks, "After studying the issue for three years,

\footnotetext{
${ }^{48}$ Nicholson, supra note 41 .

${ }^{49}$ Report of the Subcommittee on Solicitation Laws, supra note 1 at 91.

${ }^{50}$ Ibid.

${ }^{51}$ Ibid.
} 
spending millions of dollars on holding public hearings across Canada, the conclusion of the Subcommittee is that we need more research?"52

Prostitution is over-researched. There is a vast number of studies, reports and literature in Canada and internationally on prostitution. If anything, it is violence against prostitutes that requires more research. While John Lowman and others have been influential in this area, additional empirical studies and research on the causes and manifestations of violence against female prostitutes, examined within the context of male violence against women, would be extremely useful. This kind of research would help in understanding the violence, and in turn could lead to policies and programs that would have a positive impact on those engaged in prostitution. But even without additional research, we already know a great deal about violence against prostitutes. We do not need more information in order to act. The call for more research seems like an excuse for inaction and a way of justifying the lack of consensus on change and reform.

Recommendation six recommends that the Department of Justice, along with other levels of government institutions, NGO's and sex workers, coordinate research on prostitution on a priority basis in order to provide a more thorough legal analysis. This recommendation attempts to address the problems with the current legal framework pertaining to prostitution which is vague, contradictory and ineffective. Again however, this research has been completed. Legal analysis has been done in great depth and detail. Sex workers and sex workers' rights organizations have contributed to this area of research. The HIV/AIDS legal network in their analysis and critique of The Challenge of Change, accurately point out that three such analyses were prepared by organizations that

\footnotetext{
${ }^{52}$ Esther Shannon, supra note 46.
} 
appeared before the Subcommittee. ${ }^{53}$ The problem is not a lack of information but the unwillingness to act on the extensive information available. Rather than re-researching these issues, the current findings need to be put into practice and then their effectiveness evaluated.

Prior to issuing the seventh, and final recommendation, the Subcommittee states, "Members of the Subcommittee could not agree on a strategy to address the safety of individuals selling sexual services and communities overall." 54 This is a clear indication of what is to follow in their actual recommendation, and at the outset a let down to those who had hoped for more from this Subcommittee on this issue. Their recommendation states:

The majority of the Subcommittee calls for concrete efforts to be made immediately to improve the safety of individuals selling sexual services and assist them in exiting prostitution if they are not there by choice. In addition, the Federal Government should consider increasing transfer payments to the provinces to enable them to provide significant resources for income support, education, and training, poverty alleviation, and treatment for addictions, while respecting provincial area jurisdiction. ${ }^{55}$

This recommendation is extremely vague. It may be that the Subcommittee's lack of consensus led to the ambiguity of the recommendation, but whatever the reasons, the recommendation is ineffectual. What kind of concrete efforts are envisioned? There is nothing definite or explicit in this recommendation. While we cannot expect the committee to instantaneously solve the problem of violence against prostitutes, there is a fundamental problem when the mandate was to recommend changes to address the safety and needs of prostitutes, and all that materialized was this very basic and inconsequential

\footnotetext{
${ }^{53}$ The HIV/AIDS Legal Network, supra note 30 at 6. (See also my reference to these legal analyses at 139 of this chapter).

${ }_{55}^{54}$ Report of the Subcommittee on Solicitation Laws, supra note 1 at 89

${ }^{55}$ Ibid.
} 
recommendation. In the end, there is nothing new, innovative or substantive in this recommendation about how to minimize or eradicate violence against female sex workers.

And yet, this was the only recommendation that attempted to target the well being, health and safety of prostitutes, one of the Subcommittee's primary mandates. And it was the only recommendation that was specifically and completely dismissed by the Government. The Conservatives explained that they could not support recommendation number seven. They felt doing so would enable prostitutes to remain in a dangerous and degrading lifestyle. ${ }^{56}$ Rather, in the Government's official response, they reaffirm their position on prevention, education, awareness initiatives, exiting strategies and consistent enforcement of the criminal law. ${ }^{57}$ Effectively what the government is saying, is that that they are not prepared to do anything about the harassment, abuse and violence against prostitutes.

\section{Overall Response to Report and Recommendations}

\section{Feminist and Sex Worker Response}

The title of the Report, the mandate of the Report and then the actual content of the Report are at odds with one another. The title "The Challenge of Change" speaks to what has been holding us back on this issue and that is embracing change. There have been no changes in the laws, very little change in the way we view prostitutes and prostitution, and certainly no changes in the way we approach the problem of violence and abuse against these women. The title in no way indicates that this Subcommittee and

\footnotetext{
${ }^{56}$ Ibid at 91 .

${ }^{57}$ Nicholson, supra note 41.
} 
its Report were set up to address the safety and well being of sex workers, and neither do the recommendations. However, the title is an appropriate description of the Report in that, once again, we find a committee and government unable to reach a consensus, unwilling to take on the challenges and resistant to moving forward with change.

It is difficult to gauge what the general public's reaction was, as most of the public was not even aware of the Subcommittee or its Report. Ironically on the same day the report was tabled and released, The Globe and Mail ran a front page story on the murdered sex workers in Ipswich England. But in the whole paper that day there was not a word about the Report. ${ }^{58}$ The general response from the feminist community and from sex workers and social and health agencies to the final Report and its recommendations was negative. There was much disappointment and criticism. Many felt that the Report was merely a deja-vu of previous reports and its recommendations failed sex workers. Executive director Joanne Csete of the HIV/AIDS Legal Network stated,

After hearing the testimony of sex workers and sex worker organizations, the Subcommittee had a chance to make informed recommendations on how to modernize Canada's outdated laws on prostitution. Instead what we have is a report, years in the making, that does too little to protect sex workers or to promote their dignity and equality" 59

The Subcommittee and Government responses are especially disappointing when suggestions and strategies provided by sex workers and other agencies, were not reflected in the recommendations, and were apparently not considered.

\footnotetext{
${ }^{58}$ See Rukmini Callimachi, "English Town Terrorized by Prostitute Slayings" The Globe and Mail 13 December 2006, available at:

http://www.theglobeandmail.com/servlet/Page/document/v5/content/subscribe?user URL=http://www.theg lobeandmail.com\%2Fservlet\%2Fstory\%2FRTGAM.20061213.wprostituteal 213\%2FBNStory\%2FInternati onal\%2F\&ord $=120130425 \&$ brand=theglobeandmail\&force login=true (accessed 16 December 2006).

${ }^{59}$ Canadian HIV/AIDS Legal Network, Commons Report Fails Sex Workers, 13 December 2006 pg. 1 Available at: http://www.aidslaw.ca/publications/interfaces/downloadDocumentFile.php?ref=644
} 
Having fought so hard to be included, sex workers and other feminists were extremely frustrated by the final product that was completely void of concrete measures and accountability. ${ }^{60}$ As members and workers of Stella Montreal argued,

Not one single recommendation that would make sex work safe, nothing concrete that would send the message that our mothers, sisters, friends and lovers have the right to work in security. Not a single recommendation that would send the message that violence against sex workers is without compromise unacceptable. ${ }^{61}$ They passionately conclude, "Cognizant of the fact that sex workers are murdered for no other reason than they are easy targets, that our prisons are full of women whose only crime was to earn a living, the conclusion of the Subcommittee is a blow." ${ }^{, 62}$

\section{Failure to Take up the Challenge}

In the concluding remarks of their Report, the Subcommittee notes the opinions of the political parties of Canada. Members of the Liberal, New Democratic and PQ parties were of the view that sexual activities between consenting adults that do not harm others, whether payment or not is involved, should not be prohibited by the state. They feel it is essential to strike a balance between the safety of those selling sexual services without judging them, and the right of all citizens to live in peace and security. ${ }^{63}$ They sum up their position stating, "It is preferable to concentrate our efforts on combating exploitation and violence in the context of prostitution, rather than criminalizing consenting adults who engage in sex for money., ${ }^{64}$

\footnotetext{
60 "Safety Last" 22 (8) Montrealmirror.com, 04 January 2007. Available at: http://www.montrealmirror.com/2007/010407/sasha.html

${ }^{61}$ Tara Santini et al. "Déjà-vu: The Subcommittee on Solicitation Laws of the Standing Committee." Press Releases, Stella Montreal. 04 January 2007, available at: http://www.chezstella.org/stella/?q=en/medias\&PHPSESSID=b48ea2a5a0dbe755ab2a6f08b3d64504 ${ }^{62}$ Ibid.

${ }^{63}$ Report of the Subcommittee on Solicitation Laws, supra note 1 at 90 ${ }^{64}$ Ibid.
} 
The Conservative view of prostitution is in direct contrast to that of the other parties. They see prostitution as a degrading and dehumanizing act for all involved. They believe the most realistic, compassionate and responsible approach to dealing with prostitution begins by viewing prostitutes as victims. ${ }^{65}$ While the Conservative Government agrees with the Subcommittee that the status quo with respect to the enforcement of prostitution laws is unacceptable they do not provide any new alternatives. They are strongly against decriminalization and would instead use the law to target pimps and clients and to assist prostitutes out of prostitution.

The Government's response and reaction to the Report seek to highlight programs related to prostitution that the Government already has in place. In particular they mention their efforts at addressing child sexual exploitation and trafficking in persons as well as government supported, sponsored and funded initiatives such as Project KARE, the Joint Missing Women Task Force and The Native Women's Association of Canada's Sisters in Spirit. Their official response does not address violence against sex workers directly or even indirectly. The Government acknowledges that those involved in prostitution are at greater risk of abuse and exploitation and that strong and consistent responses are required. ${ }^{66}$ But they provide no indication of what these "strong and consistent" approaches and responses are, or would be.

The Government response avoids the issue of violence against prostitutes and all the testimony and evidence that speak to it. Strategies proposed to challenge the violence are ignored. The Government positions itself among those who believe that prostitution is inherently violent and exploitative, wrong under any conditions and circumstances.

\footnotetext{
${ }^{65}$ Ibid.

${ }^{66}$ Nicholson, supra note 41 .
} 
For these reasons they conclude, "This Government continues to address prostitution by focusing on reducing its prevalence. ${ }^{, 67}$ What they are effectively saying once again is that they are not willing to do anything about the violence; acting on this issue would be seen as endorsing prostitution. In maintaining this "do nothing" approach, the Government is allowing the culture of violence to persist. Sex workers remain vulnerable and continue to be harassed and abused and murdered while the Government continues to sanction this violence by sitting on its high moral horse.

${ }^{67}$ Ibid. 


\section{Chapter 7}

\section{Conclusion - Taking up the Challenge}

Throughout this thesis, I have argued that the debates and dialogues surrounding the issue of violence and abuse against prostitutes have been misfocused and misguided. We remain mired in the larger debates on whether prostitution should be eliminated or supported and this makes it impossible to get to the urgent issue of violence against prostitutes. After reading and analyzing the Subcommittee's report, and then in turn the Government's response, this recurring theme becomes apparent once again. A large part of this frustrating pattern of inaction lies in how prostitution has been constructed. As Deborah Brock points out, "Our approach to prostitution is fundamentally flawed. We generally think of it as a "social problem."1 This has resulted in much of the discussion on prostitution centering around the harm and nuisance to society, and a concern for only those aspects of prostitution that society is most alarmed about, such as juvenile prostitution and trafficking. The larger issue of violence against all prostitutes is lost in the controversy over the morality and legality of sex work.

The framework of prostitution as a social problem is even more challenging when it is applied to the issue of violence against female prostitutes. And this is precisely what occurs. What to do about violence against prostitutes becomes what to do about prostitution and we are back to square one of the debate. Prostitutes are emotionally and physically harassed by the public, pimps, and clients on a daily basis, and more pressing, they are missing and being murdered in large numbers. And the ongoing reaction from all of us: the public, the media, feminists and politicians, is debate. We begin arguing the

\footnotetext{
${ }^{1}$ Deborah Brock, Making Work, Making Trouble: Prostitution as a Social Problem. (Toronto: University of Toronto Press, 1998) at 13.
} 
same old positions about whether the "act" of prostitution should be legalized, decriminalized, eradicated or we should simply maintain the status quo. We question if prostitution is right or wrong, echoing sentiments that have been with us since the Victorian era. We continue to passionately argue that prostitution is exploitative and sexual slavery, or that it is a chosen form of work and economically empowering for some women. While these are important and fundamental questions, they are not getting us anywhere. We get caught up in these debates and while we debate, nothing changes. Women who work selling sex on the streets continue to be at risk. We are not going to be able to address the urgent problem of violence against prostitutes by rehashing debates and arguments that have not been resolved for centuries. We need to focus on preventing violence against prostitutes rather than on the status of prostitution.

\section{Re framing the Discussion}

\section{Violence against Women}

We might begin our approach to the violence experienced by prostitutes, by viewing and analyzing this issue for what it is, and that is a violence against women issue. Throughout this thesis I have drawn parallels between the violence sex workers experience and other forms of violence against women (rape and battering) in order to make this analytical connection. We have a distinct population of women who are subject to continuous abuse and overt harassment, who are treated unfairly by the justice system, and who are clearly being targeted by sexual predators and serial killers. It is their identity as prostitutes that marks them as potential victims and makes them more vulnerable, but it is their identity as women that should guide our strategies in 
challenging the violence. If we see them as women, first and foremost, not defined by what they do, we may better be able to understand and approach the issues and develop strategies. This is consistent with feminist approaches and analysis generally that seek to include all women, especially the historically voiceless and marginalized, in the broader campaign of women's rights, and in this case violence against women.

The concern over violence against sex workers is where feminists should be able to find some common ground and solidarity. Feminists have made significant advances on numerous women's issues and have united to create influential movements, many of which have been directed towards issues of violence against women, such as the battered women's movement and the movement to change Canada's rape laws. As Zoe Hilton points out,

The grassroots movement for the politicization of wife assault in the past twenty years or so was built on a network of women's group's which struggled for protection of women in their homes. These groups grew from a variety of feminist perspectives, but gained strength and adaptability by uniting on the problem of battered women. They successfully set the issue on the public agenda and their efforts eventually met with political response. ${ }^{2}$

The same momentum and support are required with respect to violence against prostitutes. We need to put our beliefs about prostitution aside, in favour of a united campaign to address this violence. This will be no easy task given the very strongly held and distinct positions and arguments on prostitution. But it is a task that needs to be undertaken in the interests of the lives and safety of sex workers. One feminist in response to the debates, said it best when she stated,

I would like to propose that we stop talking about decriminalization versus abolition for now, and instead just start working out a plan to make the lives of the women safer. We need something in place immediately. Since we can't agree

\footnotetext{
${ }^{2} \mathrm{~N}$. Zoe Hilton "One in ten: the struggle and disempowerment of the battered women's movement" (1989) 7 Canadian Journal of Family Law 313 at 314.
} 
on the legal aspects but all seem so passionate about the issue, it is time we start coming up with something else, because while we are sitting around debating it, women are suffering and dying. ${ }^{3}$

We need at least to do our best to make it safer for sex workers while prostitution continues to be practiced.

Violence against sex workers could be included in the larger campaign of violence against women, with the understanding that violence against any woman should not be tolerated. In adopting such a viewpoint, other women would be identifying with prostitutes as women. In other words, feminists and other female victims of violence would view and understand prostitutes as a group of women in a particularly unprotected situation because of their social and legal marginalization and prey to male violence as a result. ${ }^{4}$ Eileen Mcleod observing the situation in the U.K states, "Campaigns such as "Reclaim the night" - with the aim of freeing women from the threat of attack when out at night on their own - or women working in rape crisis centers, have offered their support to prostitutes as a group." ${ }^{, 5}$ Canadian women and feminists might learn from such strategies. A concerted effort between all feminists and sex workers through advocacy, anti-violence campaigns, support and assistance, should have a much stronger and more visible impact on both the public and government.

Statistics Canada in 2006 released a report titled Measuring Violence against Women: Statistical trends. ${ }^{6}$ This report was disseminated and discussed among the feminist community. Reports such as this inform women, the government and the public.

\footnotetext{
${ }^{3}$ Tori Chassin de K, Sex work: a new proposition, online posting, 19 December 2007, PARL@LISTSERV.UNB.CA.

${ }^{4}$ Eileen McLeod, "Prostitute's Working Conditions" in Prostitution. Roger Matthews and Maggie O'Neill eds. (Burlington: Ashgate, 2002) at 174.

${ }^{5}$ Ibid.

${ }^{6}$ Holly Johnson, "Measuring Violence against Women: Statistical Trends" Statistics Canada (2006) available at: http://www.statcan.ca/english/research/85-570-XIE/85-570-XIE2006001.htm
} 
They highlight all forms of violence against women and examine responses, challenges, and successes. They are an important tool in maintaining the issue of violence against women on the political agenda. It is interesting, and disappointing to note that nowhere in this Report is there mention of prostitutes being disproportionately represented among female victims of violence. This is extremely surprising especially with the recent interest and attention violence against women who work in the sex trade has received, and given the recent publication of The Challenge of Change with its mandated focus on violence against prostitutes. This is a perfect example of how the issue of violence against prostitutes is overlooked as an issue of violence against women. Violence against prostitutes continues to be compartmentalized into reports on prostitution, rather than discussions and statistics on violence and violence against women.

\section{$\underline{\text { Political Ideologies }}$}

Whatever party was in power, the Government of Canada has consistently been unwilling to take a stand on violence against prostitutes, or engage in any form of proactive innovative law reform for fear of appearing to endorse prostitution. Even though we are talking about violence against prostitutes, not prostitution per se, few politicians will take on the issue as it is seen as defending prostitution. ${ }^{7}$ Our present government stands firm behind the belief that prostitution is wrong, immoral and exploitative in any form and under any condition and is therefore unwilling to do anything to protect prostitutes or to render the conditions under which they work less dangerous. The Government takes this position and continues to ignore the issue of

\footnotetext{
${ }^{7}$ Mary Agnes Welch, "Changing Sex-Trade Laws Not Embraced" Winnipeg Free Press. 6 September, 2007. Available at: http://www.infomedia.gc.ca/justicel (accessed on 6 September 2007).
} 
violence because it is easier than separating out the many components of prostitution and examining the real reasons why violence against prostitutes occurs, and in turn is tolerated. However, recognition of violence against prostitutes as part of the larger issue of violence against women might significantly impact the government's position and response. Were they to adopt this approach, it might avoid these political ideologies that are preventing this Government, as it prevented previous governments, from acting on this issue.

The women's movement and female victims of male violence have faced and overcome similar challenges to the ones sex workers now face. All issues of violence against women have been infused with myths and stereotypes and have met resistance and indifference. After years of inaction and complete disregard for the issue, the Government was forced to respond to the prevalence of battered women in the 1980's. Women who stayed in abusive relationships were seen as weak or deserving violence for remaining with their abusive partners. Those views have changed over time. We need to examine how that happened, why that happened, and how we can perform a similar challenge to the victimization of sex workers. A shift in political ideologies and in public recognition and support of the issue, was critical in the battered women's campaign seeing a measure of success. A similar shift should be achievable in the context of violence against prostitutes.

\section{Moving forward}

Rather than fund more research and committees and spend millions more dollars to produce reports that merely confirm what we already know, Canadian society and the Government of Canada need to find a way out of the prostitution debates that will lead to 
change and action. There are many insightful, innovative and feasible strategies, recommendations and suggestions put forth by legal experts, academics, feminists, and most importantly sex workers themselves, that could guide us in the right direction. Unifying around what we do agree on rather than what we do not and shifting the focus, would shift the dialogue and debate. Framing the issue as one of violence against a particular group of women, rather than as a social "problem" focused on the legality and morality of the work or activities these women perform, might have a significant impact on future challenges and approaches to violence against prostitutes.

It is not prostitution per se that government, feminists and the public would be supporting, it is an end to violence against those who engage in prostitution. Violence from men towards women is accepted to such a degree and is so all pervasive that it requires immense changes in male attitudes and behaviour on a vast scale to shift, allied with changes of attitude among the public, government, women and feminists as to the acceptability of violence, and a readiness to work collectively to extirpate it. ${ }^{8}$ A corollary of this view is that the solution to the problem of violence experienced by prostitutes lies in just such long term change. ${ }^{9}$

\section{Envisioning the Future}

It is not prostitutes who are a "moral stain" on our society, it is us and our willful indifference to their circumstances that reflects a lack of humanity and justice. Our attitude is a shameful reflection of our hypocrisy and treatment of women in our society, in particular marginalized women. What the Canadian public thinks and feels about

\footnotetext{
${ }^{8}$ McLeod, note 4 at 174 .

${ }^{9}$ Ibid.
} 
prostitutes and prostitution matters and this clearly has an effect on how prostitutes are treated, and how seriously their abuse is taken. To eradicate violence against sex workers, society must reject it. ${ }^{10}$ It has taken the mass murder of a large number of women to get society thinking about and examining these issues. The trial and subsequent conviction of Robert Pickton may provide us with some insight on changing attitudes about women involved in prostitution, in particular those who have been victims of extreme violence. This case has brought the issue to the attention of the public, but it remains to be seen the extent to which if any, this high profile case may have altered the public's view of prostitution, and women engaged in prostitution. It also remains to be seen what impact it has had on the livelihoods of those women working on the streets. ${ }^{11}$ Unfortunately, what this case and subsequent trials and investigations of missing and murdered sex workers have not done to date is change the Government's attitude or position. The Government has set a shameful example for the public by its inaction on the issue, thereby sending the message that they condone this violence.

My thesis has adopted a new approach to the literature and discussion of prostitution in Canada. Specifically I have not looked at the social phenomena of prostitution. Rather, I have looked at an equally important phenomena and that is the Government's systematic inaction towards violence against sex workers. The Government's response to a crisis is as important as the crisis itself. In examining this, I have attempted to not engage in the traditional feminist debates or the moral and legal

\footnotetext{
${ }^{10}$ Patricia Easteal, "Violence Against Women in the Home: How Far Have We come? How Far to Go?" (1994) no. 37 Family Matters 86 at 88.

${ }^{11}$ See Stephanie Levitz, "Glare of Pickton trial never reached Vancouver's Eastside" CNEWS, 09 December 2007. Available at: http://cnews.canoe.ca/CNEWS/Canada/PicktonTrial/Features/2007/12/09/pf-4716103.html (accessed on 20 January 2008).
} 
debates surrounding prostitution. I have instead focused on the discrimination, abuse, harassment and violence experienced by female street level sex workers, treating this not as an inherent danger in selling sex or even as an "occupational hazard" but as male violence against women manifested in a particularly misogynist form. In this way, I have analyzed violence against prostitutes as part of the larger issue of violence against women seeing prostitutes as a particularly vulnerable and marginalized group of women. As obvious as this analytical connection may seem, we have clearly neglected to see it as such.

There are other voiceless and invisible victims of violence. Homeless women, drug addicted women, disabled women and lesbians are virtually absent from the research on violence. They are examples of vulnerable women who are at an increased risk of violence due to their extreme marginalization. ${ }^{12}$ Violence against these particular groups and violence against prostitutes have not been traditionally included in the literature and campaigns on violence against women in general. Very little has been published in the social work literature on violence in street culture, especially from the perspective of those involved. ${ }^{13} \mathrm{~A}$ gap exists in our professional understanding of violence against prostitutes and in our ability to develop adequate models to respond to the needs of prostitutes and to address the violence. ${ }^{14}$ I hope that my thesis has contributed to lessening this gap.

What does the future hold for women who work as street level sex workers in a country that effectively sanctions the discrimination, abuse and violence they face?

\footnotetext{
${ }^{12}$ Celia Williamson \& Gial Folaron, "Violence, Risk, and Survival Strategies of Street Prostitution" (2001) 23 Western Journal of Nursing Research 463 at 464.

${ }^{13}$ Ibid.

${ }^{14}$ Ibid.
} 
Committees, reports, evidence and murder trials have yet to effect change. The current Charter challenges underway provide some hope that law reform may be forced by the courts in the near future, however one cannot predict what that outcome will be and as I have argued throughout, more than legal change is required. There is much work ahead for sex workers and feminists and those who support the cause to end violence against prostitutes. Like other politically charged issues such as abortion and gay marriage, the barriers are many. It is no easy task changing laws which are deeply imbedded in a particular moral ideology, or changing society's views especially when our Government endorses and condones this moral ideology. None the less, if we as feminists, the public, the justice system and the Canadian Government adopt the common framework that emphasizes violence against prostitutes as an issue of violence against women, and seek to remove ourselves from the unproductive moral and legal debates surrounding prostitution, we will see change. The challenges to violence against sex workers are there - but the Canadian Government needs to finally take up the challenge that they have studied, talked about, and at the same time avoided, for decades. 


\section{BIBLIOGRAPHY}

\section{Books and Journals}

Bell, Shannon. Reading, Writing and Re writing the Prostitute Body (Bloomington: Indiana University Press, 1994)

Beauvoir, Simone de. Le Deuxième Sexe (Paris: Gallimard, 1949)

Brannigan, A. and Fleischman, J. "Juvenile Prostitution and Mental Health: Policing Delinquency or Treating Pathology?" (1989) 4 Canadian Journal of Law and Society 77

Brock, Deborah. Making Work, Making Trouble: Prostitution as a Social Problem (Toronto: University of Toronto Press, 1998)

Bullough, Vern and Bullough, Bonnie. Prostitution: An Illustrated Social History (New York: Crown Publishers, 1978)

Butler, Judith. Gender Trouble: feminism and the subversion of identity (New York: Routledge, 1990)

Canadian Advisory Council on the Status of Women. Prostitution in Canada (Ottawa: Status of Women Canada, 1984)

Canadian Advisory Council on the Status of Women, Assessing Violence against Women, a Statistical Profile (Ottawa: Status of Women Canada, 2002)

Canadian Advisory Council on the Status of Women, Wife Battering in Canada: The Vicious Circle (Ottawa: Ministry of Supply and Services Canada, 1980)

Chapkis, Wendy. Live Sex Acts: Women Performing Erotic Labour (New York: Routledge, 1997)

Cohen, Anthony P. Belonging: Identity and Social Organization in British Rural Cultures (St. John's: Institute of Social and Economic Research, 1982)

Cohen, Anthony P. The Symbolic Construction of Community (New York: Tavistock Publications, 1985)

Crowell, Nancy. A and Burgess, Ann W. Understanding Violence Against Women (Washington D.C: National Academy Press, 1996) 
Curtis, Perry L. Jack the Ripper and the London Press, (New Haven: Yale University Press, 2001)

Dalla, Rochelle et al., "You Just Give Them What They Want and Pray They Don't Kill You: Street Level Sex Workers' Reports of Victimization, Personal Resources and Coping Strategies" (2003) 9 Violence Against Women 1367

Dobash, Emerson R. and Dobash, Russell P. Rethinking Violence Against Women (Oaks, California: Sage Publications, 1998)

Easteal, Patricia. "Violence Against Women in the Home: How Far Have We Come? How Far to Go?" (1994) no.37 Family Matters 86

Evans, Stewart and Rumbelow, Donald. Jack the Ripper: Scotland Yard Investigates (Stroud: Sutton Publishing, 2006)

Goode, Erich. Moral Panics: The Social Construction of Deviance (Oxford: Blackwell, 1994)

Graves, F. Street Prostitution: Assessing the Impact of the Law, Halifax (Ottawa: Department of Justice, 1989)

Henley, Nancy. Body Politics: Power Sex and Non Verbal Communication (Englewood Cliffs, N.J: Prentice-Hall, 1977)

Hilton, Zoe N. "One in ten: the struggle and disempowerment of the battered women's movement" (1989) 7. Canadian Journal of Family Law 313

Jesson, J. "Understanding Adolescent Female Prostitution: A Literature Review" (1993) 23(5) British Journal of Social Work 517

Lowman, John. "You Can Do it, But Don't Do it Here: Some Comments on Proposals for the Reform of Canadian Prostitution Law" in Regulating Sex: An Anthology of Commentaries on the Findings of The Badgley and Fraser Reports. J. Lowman, MA Jackson, TS Palys \& S. Gavigan Eds (Burnaby B.C: School of Criminology, Simon Fraser University, 1986) 193

Lowman, John "Canada" in Prostitution: An International Handbook on Trends, Problems and Policies. Nanette J. Davis ed. (Westport: Greenwood Press, 1993) 56

Lowman, John. "Prostitution Law Reform in Canada" Toward Comparative Law in the $21^{s t}$ Century. Institute of Comparative Law in Japan ed. (Tokyo: Chuo University Press, 1998) 
Lowman, John. "Violence and the Outlaw Status of Street Prostitution in Canada" (2000) 6(9) Violence Against Women 987

McIntyre, Sheila. "Tracking and resisting backlash against equality gains in sexual offence law" (2000) 20(3) Canadian Woman Studies 72

Mckeganey, Neil \& Barnard, Marina. Sex Work on the Streets: Prostitutes and their Clients (Buckingham: Open University Press, 1996)

McLaren, John. "The Fraser Committee: The Politics of a Special Committee" in Regulating Sex: An Anthology of Commentaries on the Findings of The Badgley and Fraser Reports. J. Lowman, MA Jackson, TS Palys \& S. Gavigan Eds. (Burnaby B.C: School of Criminology, Simon Fraser University, 1986) 145

McLaren, John P.S. "Chasing the Social Evil: Moral Fervour and the Evolution of Canada's Prostitution Laws, 1867-1917" (1986) 1 Canadian Journal of Law and Society 125

McLeod, Eileen. "Prostitute's Working Conditions" in Prostitution. Roger Matthews and Maggie O'Neill eds. (Burlington: Ashgate, 2002) 145

Miko, Frances T. and Jean-Hyun Park, Grace. "Trafficking in Women and Children: The U.S and International Response" Report for Congress (Congressional Research Service, Library of Congress, 18 March 2002)

Monto, Martin A. "Female Prostitution, Customers, and Violence" (2004) 10(2) Violence Against Women 160

O'Connell Davidson, Julia. Prostitution, Power and Freedom (Ann Arbour: University of Michigan Press, 1998)

O’Neill, Maggie "Researching Prostitution and Violence: Towards a Feminist Praxis" in Women, Violence and Male Power: Feminist Activism, Research and Practice. Hester et al. eds. (Philadelphia: Open University Press, 1996) 130

Pheterson, Gail. The Prostitution Prism (Amsterdam: Amsterdam University Press, 1996)

Phoenix, Joanna. Making Sense of Prostitution (Hampshire: Macmillan Press, 1999)

Potterat. John J. et al., "Mortality in a Long Term Open Cohort of Prostitute Women" (2004) 159 (8) American Journal of Epidemiology 778

Raphael, Jody and Shapiro, Deborah. "Violence in Indoor and Outdoor Prostitution Venues" (2004) 10(2) Violence Against Women 126 
Razack, Sherene, "Gendered Racial Violence and spatialized Justice: The Murder of Pamela George" in Race, Space and the Law: Unmapping a White Settler Society. (Toronto: Between the Lines, 2002) 121

Sheehy, Elizabeth. "From women's duty to resist to men's duty to ask: how far have we come?” (2000) 20(3) Canadian Woman Studies 98

Sheehy, Elizabeth. "Legal Responses to Violence Against Women" in Violence Against Women: New Canadian Perspectives, Katherine M.J. McKenna and June Larkin eds. (Toronto: Inanna Publications and Education, 2002) 473

Shaver, Frances M. "The Regulation of Prostitution: Avoiding the Morality Trap" (1994) 9(1) Canadian Journal of Law and Society 25

Stansell, Christine. City of Women: Sex and Class in New York, 1789-1860 (New York: Random House, 1986)

Tang, Kwong-leung. "Rape Law Reform in Canada: The Success and Limits of Legislation" (1998) 42(3) International Journal of Offender Therapy and Comparative Criminology 258

Walkowitz, Judith. Prostitution and Victorian Society: Women, Class and the State (New York: Cambridge University Press, 1980)

Williamson, Celia and Folaron, Gial. "Violence, Risk, and Survival Strategies of Street Prostitution" (2001) 23 Western Journal of Nursing Research 463

\section{Government Publications}

Bittle, Steve. Youth Involvement in Prostitution: A Literature Review and Annotated Bibliography (Ottawa: Research and Statistics Division, Department of Justice, 2002)

Brannigan, A. Knafla, L., and Levy, C. Street Prostitution: Assessing the Impact of the Law, Calgary, Regina and Winnipeg (Ottawa: Department of Justice, 1989)

Cool, Julie. "Prostitution in Canada: An Overview" Library of Parliament PRB 04-43E, (Ottawa: Parliamentary Information and Research Service, 2004)

Duchesne, D. "Street Prostitution in Canada" Juristat 17:2 (Ottawa: Statistics Canada, 1997)

Federal/Provincial/Territorial Working Group on Prostitution, Report and Recommendations in Respect of Legislation, Policy, and Practices Concerning 
Prostitution Related Activities (December 1998)

<http://www.justice.gc.ca/en/news/nr/1998/toc.html>

Fedorowycz, Orest. "Homicide in Canada” Juristat 18:12 (Ottawa: Statistics Canada, 1997)

Gemme, R., Payment, N. and Malenfant, L. Street Prostitution: Assessing the Impact of the Law, Montreal (Ottawa: Department of Justice, 1989)

Guide to the Federal Government Response to the Reports on Sexual Abuse of Children, Pornography and Prostitution (Ottawa: Department of Justice, 1986)

Lèsèleuc, Sylvain de. "Criminal Victimization in the Workplace" Canadian Centre for Justice Statistics. Catalogue no. 85F0033MIE - No. 013, 2004 $<$ http://www.statcan.ca/english/research/85F0033MIE/2007013/findings/profile.h $\underline{\mathrm{tm}>}$

Johnson, Holly. Measuring Violence against Women: Statistical Trends. Statistics Canada, $2006<$ http://www.statcan.ca/english/research/85-570-XIE/85-570$\underline{\mathrm{XIE} 2006001 . \mathrm{htm}>}$

Lowman, John. Street Prostitution: Assessing the Impact of the Law, Vancouver (Ottawa: Department of Justice, 1989)

Lowman, John and Fraser, Laura. Violence against Persons Who Prostitute: The Experience in British Columbia. Technical Report No. TR1996-14e. (Ottawa: Department of Justice Canada, 1996) < <ttp://mypage.uniserve.ca/ lowman/>

Moyer, S and Carrington, P.J. Street Prostitution: Assessing the Impact of the Law, Toronto (Ottawa: Department of Justice, 1989)

Nicholson, Robert (Minister of Justice) Government Response to the Sixth Report of the Standing Committee on Justice and Human Rights $<$ http://cmte.parl.gc.ca/cmte/CommitteePublication.aspx?COM=10474\&Lang=1 $\underline{\text { \&SourceId }=199347>}$

Report of the Special Committee on Pornography and Prostitution: Pornography and Prostitution in Canada (Ottawa: Canadian Government Publishing Centre, 1986)

Robertson, James R. "Prostitution," Current Issue Review 82-2E (Ottawa: Library of Parliament, 1999)

Sexual Offences against Children: Report of the Special Committee on Special Offences against Children and Youth (Ottawa: Supply and Services Canada, 1985) 
Standing Committee on Justice and Human Rights Fourth Report (respecting soliciting for the purpose of prostitution). Minutes of Proceedings Issue No. 42, (4 October 1990)

Subcommittee on Solicitation Laws, The Challenge of Change: A Study of Canada's Criminal Prostitution Laws (December 2006)

$<$ http://cmte.parl.gc.ca/cmte/CommitteePublication.aspx?COM=10474\&Lang=1 $\underline{\text { \&Source Id }=190754>}$

Wolff, L and Geissel, D. "Prostitution" Juristat, 13:4 (Ottawa: Statistics Canada, 1993)

\section{Online Reports and Publications}

Amnesty International, Stolen Sisters: Discrimination and Violence against Indigenous Women in Canada (October 2004)

<http://www.amnesty.org/en/library/info/AMR20/001/2004>

Bruckert, Christine and Parent, Colette. How to Respond to the Needs of Street Sex Workers in the Ottawa-Gatineau Region (June 2006) $<\underline{\text { http://francofemmes.org/aocvf/> }}$

Canadian HIV/AIDS Legal Network, Not Up to the Challenge of Change: An analysis of the report of the Subcommittee on Solicitation Laws, (February 2007) <www.aidslaw.ca/sexwork>

Canadian HIV/AIDS Legal Network, Commons Report Fails Sex Workers (2006) $<$ http://www.aidslaw.ca/publications/mediaEN.php>

Davis, Sylvia and Shaffer, Martha. Prostitution in Canada: The Invisible Menace of the Menace of Invisibility (1994) <http://www.walnet.org/csis/papers/sdavis.html >

Gall, Gregor. “The Unionization of Sex Workers" Frontline (March 2004) 13 $<$ http://www.redflag.org.uk/frontline/13/13sexwork.html >

Kinnell, Hilary "Murderous Clients and Indifferent Justice: Violence Against Sex Workers in the U.K" (2001) 4 Research for Sex Work $<$ http://hcc.med.vu.nl/artikelen/kinnell.htm $>$

Lowman, John. Submission to the Subcommittee on Solicitation Laws of the Standing Committee on Justice, Human Rights, Public Safety and Emergency Preparedness (2005) <http://mypage.uniserve.ca/ lowman/>

Maggie's Toronto, Pamela George Murder Trial (2006) $<$ http://www.walnet.org./csis/regina 96/pam_george.html> 
Maggie's Toronto, Junger Commission submission (1995)

$<$ www.walnet.org/csis/groups/maggies/>

Metropolitan Police, The Enduring Mystery of Jack the Ripper

$<\underline{\text { http://www.met.police.uk/history/ripper.htm> }}$

O'Neill, Maggie. "Prostitution, Feminism and Critical Praxis: Profession Prostitution?" (Summer 1996) Umbruch Neue Sozial-Wissenschaftliche Perspektiven a special edition of the Austrian Journal of Sociology Johanna Hofbauer and Jorg Flecker eds.

$<$ http://www.staffs.ac.uk/schools/humanities and soc sciences/sociology/level3/ prost 3. htm $>$

Pivot Legal Society. Voices for Dignity, (March 2004)

$<$ http://www.pivotlegal.org/Publications/reportsvfd.htm>

Pivot Legal Society. Beyond Decriminalization: Sex Work, Human Rights, and a New Framework for Law Reform, (2006)

$<$ http://www.pivotlegal.org/Publications/reportsvfd.htm>

Santini, Tara et al. "Déjà-vu: The Subcommittee on Solicitation Laws of the Standing Committee." Stella Montreal. Press Releases (4 January 2007)

$<$ http://www.chezstella.org/stella/?q=en/medias\&PHPSESSID=b48ea2a5a0dbe75 5ab2a6f08b3d64504>

Shaver, Frances M. Prostitution (2006)

$<$ http://www.thecanadianencyclopedia.com/index.cfm?PgNm=TCE\&Params=A1 $\underline{\text { SEC826746> }}$

Stella Montreal. Stella's Bulletin (updated March 2008)

$<$ http://www.chezstella.org/stella/?q=en/tools >

Sex Trade Advocacy and Research (STAR) Safety, Security and the Well Being of Sex Workers: A Report Submitted to the House of Commons Subcommittee of Solicitation Laws (July 2006)

$<$ http://web2.uwindsor.ca/courses/sociology/maticka/star/pdfs/safety and securit $\mathrm{y}$ report final version.pdf.>

United Nations General Assembly, The Declaration on the Elimination of Violence Against Women (20 December 1993) <http://www.unhchr.ch/huridocda/huridoca.nsf/(Symbol)/A.RES.48.104.En>

Van der Meulen, Emily. Towards More Egalitarian Policies on Prostitution: What Canada Can Learn from the International Community, Conference Presentation (2005) $<\underline{\text { http://www.sfu.ca/espconference2005/web/presentations/Panel\%20D1.doc }>~}$ 


\section{Testimony and Online Email Postings}

Testimony of Jenn Clamen to Subcommittee on Solicitation Laws of the Standing Committee on Justice, Human Rights, Public Safety and Emergency Preparedness. Number 033, $1^{\text {st }}$ Session, $38^{\text {th }}$ Parliament. Monday, May $30^{\text {th }} 2005$ $<$ http://cmte.parl.gc.ca/cmte/CommitteePublication.aspx?SourceId=127180\&Lan $\mathrm{g}=1 \& \mathrm{PARLSES}=381 \& \mathrm{JNT}=0 \& \mathrm{COM}=9243>$

Testimony of Kate Gibson to the Subcommittee on Solicitation Laws of the Standing Committee on Justice and Human Rights, Public Safety and Emergency Preparedness. Number $017,1^{\text {st }}$ Session, $38^{\text {th }}$ Parliament. Tuesday March $29^{\text {th }}$ 2005

$<$ http://cmte.parl.gc.ca/cmte/CommitteePublication.aspx?SourceId=127180\&Lan $\mathrm{g}=1 \& \mathrm{PARLSES}=381 \& \mathrm{JNT}=0 \& \mathrm{COM}=9243>$

Testimony of Ms Raven Bowen the Subcommittee on Solicitation Laws of the Standing Committee on Justice and Human Rights, Public Safety and Emergency Preparedness. Number 017, $1^{\text {st }}$ Session, $38^{\text {th }}$ Parliament. Tuesday March $29^{\text {th }}$ 2005

$<$ http://cmte.parl.gc.ca/cmte/CommitteePublication.aspx?SourceId=127180\&Lan $\mathrm{g}=1 \& \mathrm{PARLSES}=381 \& \mathrm{JNT}=0 \& \mathrm{COM}=9243>$

Shannon, Esther, Prostitution-Murders, online posting, 14 December 2006, PARL@LISTSERV.UNB.CA

Tori Chassin de K, Sex work: a new proposition, online posting, 19 December 2007, PAR-L@LISTSERV.UNB.CA.

\section{Media}

Bailey, Sue. "Making Plans to Thwart Serial Killers" The Chronicle Herald.ca, 24

September $2007<$ http://thechronicleherald.ca/print article.html?story=898508>

Durkan, Sean. "Most Hooker Killers Go Free" Toronto Sun, 14 February 1997

Gardner, Dan. Courting Death: The Law Has Hounded Hookers out of Safe areas, Part $1 \& 2$, June $2002<$ http://www. missingpeople.net/the law has hounded hookersjune $15,2002 . \mathrm{htm}>$

Kines, Lindsay et al. "Robert Pickton on Trial" Vancouver Sun $<$ http://www.canada.com/vancouversun/features/pickton/index.html>

Kleiss, Karen. "Project KARE on Trail of Serial Killers" Edmonton Journal, 26 October 2007 
$<$ http://www.canada.com/edmontonjournal/news/cityplus/story.html?id=fffdc9989279-4819-912e-b6972e51b5fa>

Landsberg, Michele. "Spousal abuse sparks backlash against victims" Toronto Star, 6 July 2003

Rankin, Jim. "Woman Working Street Corner Slain” Toronto Star, 9 March, 1998

Whitnall, Catherine. "Where the lines blur between victim and attacker" Kawartha Lakes This Week, 24 January 2008

Staff and agencies. "Man Remanded over Ipswich Murders" Guardian Unlimited, 22 December 2006 $<$ http://www.guardian.co.uk/suffolkmurders/story/0,,1977700,00.html $>$

"Bakker Gets Ten Years for Sexual Assaults" CBC News, 2 June 2005. $<$ http://www.cbc.ca/canada/british-columbia/story/2005/06/02/bc bakkersentenced20050602.html>

“Alberta Man Charged in Second Prostitute's Slaying" CBC News, 2 January 2007. $<$ http://www.cbc.ca/canada/edmonton/story/2007/01/02/project-kare.html $>$

"Gatineau Park Slaying Victim Was Troubled Mother of 3" CBC News, 12 December $2006<$ http://www.cbc.ca/canada/ottawa/story/2006/12/12/gatineau-murder.html >

"Rapist Given Five Life Sentences" BBC News, 23 July 2002 $<$ http://www.bbc.co.uk/southyorkshire/news/2002/07/23/rape.shtml>

"Green River Killings" The Seattle Times, 19 November 2004 $<$ http://seattletimes.nwsource.com/html/greenriverkillings/>

"Why Serial Killers Target Prostitutes" CBC News, 19 December, 2006

"Edmonton's Murdered Women" CBC News, 19 May 2006 $<$ http://www.cbc.ca/includes/printablestory.jsp>

"Safety Last" Montrealmirroronline, January 2007 $<$ http://www.montrealmirror.com/2007/010407/sasha.html>

"Ottawa Sex Trade Customers, You've Got Mail" CBC News Online, 02 October 2007 $<$ http://www.cbc.ca/canada/ottawa/story/2007/10/02/ot-johns-071002.html> 


\section{Cases, Acts, and Legislation}

R. v. Peters [1992] B.C.J. 2126 (B.C.C.A)

R. v. Allender [1996] B.C.J 224

R. v. Hutt (1978), 82 D.L.R (3d) 95

R. v. Skinner, (1990) 1 S.C.R. 1235

Bedford v. The Queen: Ontario Superior Court Application March 2007 Court File No. 07-CV-329807PD1

Downtown Eastside sex workers united against violence v. The Queen: BC Supreme Court Statement August 2007 SO75285

2 Vict. (1) (1839), c. 2 (Lower Canada), reprinted in Revised Acts and Ordinances of Lower Canada 1845, class B

5 Geo. IV (1824), c. 83 (England); and $2 \& 3$ Vict. (1839), c. 47 (England)

The Identification of Criminals Act. (R.S., 1985, c. I-1)

An Act to Amend the Criminal Code, Bill C-27 1997

Canadian Charter of Rights and Freedoms, Part I of the Constitution Act, 1982, being Schedule B to the Canada Act 1982 (U.K.), 1982, c.11. 


\section{Appendix}

Prostitution related legislation in the Criminal Code of Canada (R.S.C, 1985, c. C-46 as amended)

BAWDY-HOUSES

Keeping common bawdy-house

210. (1) Every one who keeps a common bawdy-house is guilty of an indictable offence and liable to imprisonment for a term not exceeding two years.

Landlord, inmate, etc.

(2) Every one who

(a) is an inmate of a common bawdy-house,

(b) is found, without lawful excuse, in a common bawdy-house, or

(c) as owner, landlord, lessor, tenant, occupier, agent or otherwise having charge or control of any place, knowingly permits the place or any part thereof to be let or used for the purposes of a common bawdy-house,

is guilty of an offence punishable on summary conviction.

Notice of conviction to be served on owner

(3) Where a person is convicted of an offence under subsection (1), the court shall cause a notice of the conviction to be served on the owner, landlord or lessor of the place in respect of which the person is convicted or his agent, and the notice shall contain a statement to the effect that it is being served pursuant to this section.

\section{Duty of landlord on notice}

(4) Where a person on whom a notice is served under subsection (3) fails forthwith to exercise any right he may have to determine the tenancy or right of occupation of the person so convicted, and thereafter any person is convicted of an offence under subsection (1) in respect of the same premises, the person on whom the notice was served shall be deemed to have committed an offence under subsection (1) unless he proves that he has taken all reasonable steps to prevent the recurrence of the offence. 
Transporting person to bawdy-house

211. Every one who knowingly takes, transports, directs, or offers to take, transport or direct, any other person to a common bawdy-house is guilty of an offence punishable on summary conviction.

\section{PROCURING}

\section{Procuring}

212. (1) Every one who

(a) procures, attempts to procure or solicits a person to have illicit sexual intercourse with another person, whether in or out of Canada,

(b) inveigles or entices a person who is not a prostitute to a common bawdy-house for the purpose of illicit sexual intercourse or prostitution,

(c) knowingly conceals a person in a common bawdy-house,

(d) procures or attempts to procure a person to become, whether in or out of Canada, a prostitute,

(e) procures or attempts to procure a person to leave the usual place of abode of that person in Canada, if that place is not a common bawdy-house, with intent that the person may become an inmate or frequenter of a common bawdy-house, whether in or out of Canada,

$(f)$ on the arrival of a person in Canada, directs or causes that person to be directed or takes or causes that person to be taken, to a common bawdy-house,

( $g$ ) procures a person to enter or leave Canada, for the purpose of prostitution,

(h) for the purposes of gain, exercises control, direction or influence over the movements of a person in such manner as to show that he is aiding, abetting or compelling that person to engage in or carry on prostitution with any person or generally,

(i) applies or administers to a person or causes that person to take any drug, intoxicating liquor, matter or thing with intent to stupefy or overpower that person in order thereby to enable any person to have illicit sexual intercourse with that person, or

(j) lives wholly or in part on the avails of prostitution of another person, 
is guilty of an indictable offence and liable to imprisonment for a term not exceeding ten years.

\section{Living on the avails of prostitution of person under eighteen}

(2) Despite paragraph (1)(j), every person who lives wholly or in part on the avails of prostitution of another person who is under the age of eighteen years is guilty of an indictable offence and liable to imprisonment for a term not exceeding fourteen years and to a minimum punishment of imprisonment for a term of two years.

Aggravated offence in relation to living on the avails of prostitution of a person under the age of eighteen years

(2.1) Notwithstanding paragraph (1)(j) and subsection (2), every person who lives wholly or in part on the avails of prostitution of another person under the age of eighteen years, and who

(a) for the purposes of profit, aids, abets, counsels or compels the person under that age to engage in or carry on prostitution with any person or generally, and

(b) uses, threatens to use or attempts to use violence, intimidation or coercion in relation to the person under that age,

is guilty of an indictable offence and liable to imprisonment for a term not exceeding fourteen years but not less than five years.

\section{$\underline{\text { Presumption }}$}

(3) Evidence that a person lives with or is habitually in the company of a prostitute or lives in a common bawdy-house is, in the absence of evidence to the contrary, proof that the person lives on the avails of prostitution, for the purposes of paragraph $(1)(j)$ and subsections (2) and (2.1).

\section{$\underline{\text { Offence }- \text { prostitution of person under eighteen }}$}

(4) Every person who, in any place, obtains for consideration, or communicates with anyone for the purpose of obtaining for consideration, the sexual services of a person who is under the age of eighteen years is guilty of an indictable offence and liable to imprisonment for a term not exceeding five years and to a minimum punishment of imprisonment for a term of six months. 


\section{OFFENCE IN RELATION TO PROSTITUTION}

\section{Offence in relation to prostitution}

213. (1) Every person who in a public place or in any place open to public view

(a) stops or attempts to stop any motor vehicle,

(b) impedes the free flow of pedestrian or vehicular traffic or ingress to or egress from premises adjacent to that place, or

(c) stops or attempts to stop any person or in any manner communicates or attempts to communicate with any person

for the purpose of engaging in prostitution or of obtaining the sexual services of a prostitute is guilty of an offence punishable on summary conviction.

\section{Definition of "public place"}

(2) In this section, "public place" includes any place to which the public have access as of right or by invitation, express or implied, and any motor vehicle located in a public place or in any place open to public view. 